\title{
44. A HISTORY OF SEDIMENT LITHOFACIES IN THE SOUTH ATLANTIC OCEAN
}

\author{
Floyd W. McCoy, Lamont-Doherty Geological Observatory, Columbia University, Palisades, New York \\ and \\ Herman B. Zimmerman, Department of Civil Engineering, Union College, Schenectady, New York
}

\begin{abstract}
Changes in sediment types (lithofacies) and sediment components (carbonate, foraminifers, calcareous nannoplankton) in the South Atlantic Ocean from Early Cretaceous through Pliocene are portrayed on a series of palinspastic maps which graphically document the sedimentological succession as this ocean basin evolves. Determination of paleolithofacies is based upon smear slide analyses of dated sediment from the base of over 300 piston cores and dredges which provides a broad regional coverage and supplements DSDP drilling data (with Leg 39 results as the primary data base). These maps graphically illustrate the development of oceanic circulation, CCD levels, terrigenous sediment influx, and biological productivity concomitant with changing sea-floor physiography, cycles of transgression and regression, and the Tertiary climatic deterioration.
\end{abstract}

\section{INTRODUCTION}

Clear delineation of the changing patterns in sediment distribution is vital to understanding the history of an ocean basin. The main impetus for oceanic paleoenvironmental analysis comes from deep-sea drilling, which makes possible the reconstruction of lithofacies patterns. Cook (1975) used DSDP data to conduct comparable research on a limited scale in the eastern equatorial Pacific. His paleogeologic facies maps, although constructed on the basis of the present geographical positions of the sites, portray a Tertiary depositional history that is quite complex and is controlled by subtle oceanic mechanisms. Maxwell et al. (1970), Hess et al. (1974), and Cook (1975) each attempted to establish diachronous rock-stratigraphic units (formations) which are lithologically continuous over wide areas. Although we do not adopt or use this nomenclature here, we believe that studies of paleolithofacies will aid considerably in establishing the continuity of oceanic lithologic units between DSDP sites, and will aid in paleo-environmental interpretation.

Ewing et al. (1973), on the basis of seismic reflection and refraction data, presents a picture of the thickness and distribution of sediment in the Atlantic. Such isopach maps illustrate the reasonably symmetrical nature of sediment distribution and the control on this distribution by sea-floor spreading processes, proximity of continental sources, and by the relationship of carbonate compensation depths (CCD) to water depth.

Sedimentation in the South Atlantic occurs within the tectonic framework of an expanding ocean basin that has passive continental margins on either side. Fresh-water discharge into the Atlantic constitutes drainage from well over one-half of the earth's land area, and results in a nigh rate of terrigenous influx and deposition. Continental sources, accordingly, play an important role in determining the character of deep sediments of the Atlantic on a regional basis. The north-south orientation of the Atlantic also allows for the greatest influence by climatic variables upon the composition and geochemistry of sediments. Further, the Atlantic forms the major oceanic connection between the two polar regions, so that interchange of deep and intermediate water masses is considerable, and introduces the additional effect of bottom current movement.

Geomorphologically, the Mid-Atlantic Ridge and the Rio Grande Rise-Walvis Ridge system divide the South Atlantic basin into several distinct second order basins (Figure 1). Although often breached, the ridge systems form effective barriers to water mass movements and sediment transport. This restriction of bottom transport between basins often produces a regional and distinctive character in bottom sediments.

This investigation is an attempt to map and interpret sediment distributions by combining DSDP data with all available piston-core information, thereby attaining the widest areal coverage of the basin through time. Because time was limited, it was necessary to confine this investigation for the most part to oceanic and continental slope material. However, a wealth of applicable data exists concerning the inner reaches of the continental margin and relating to the earliest history of the basin. Only that which was easily accessible is included here. In the near future, we hope to expand this study by including that additional material as well as data from subsequent DSDP legs.

\section{METHOD}

\section{Data Base}

The Deep Sea Drilling Project (DSDP) has drilled 28 sites (on Legs 3, 4, 14, 36, and 39) in the South Atlantic Ocean. Two additional legs, 40 and 41 , also were in the 


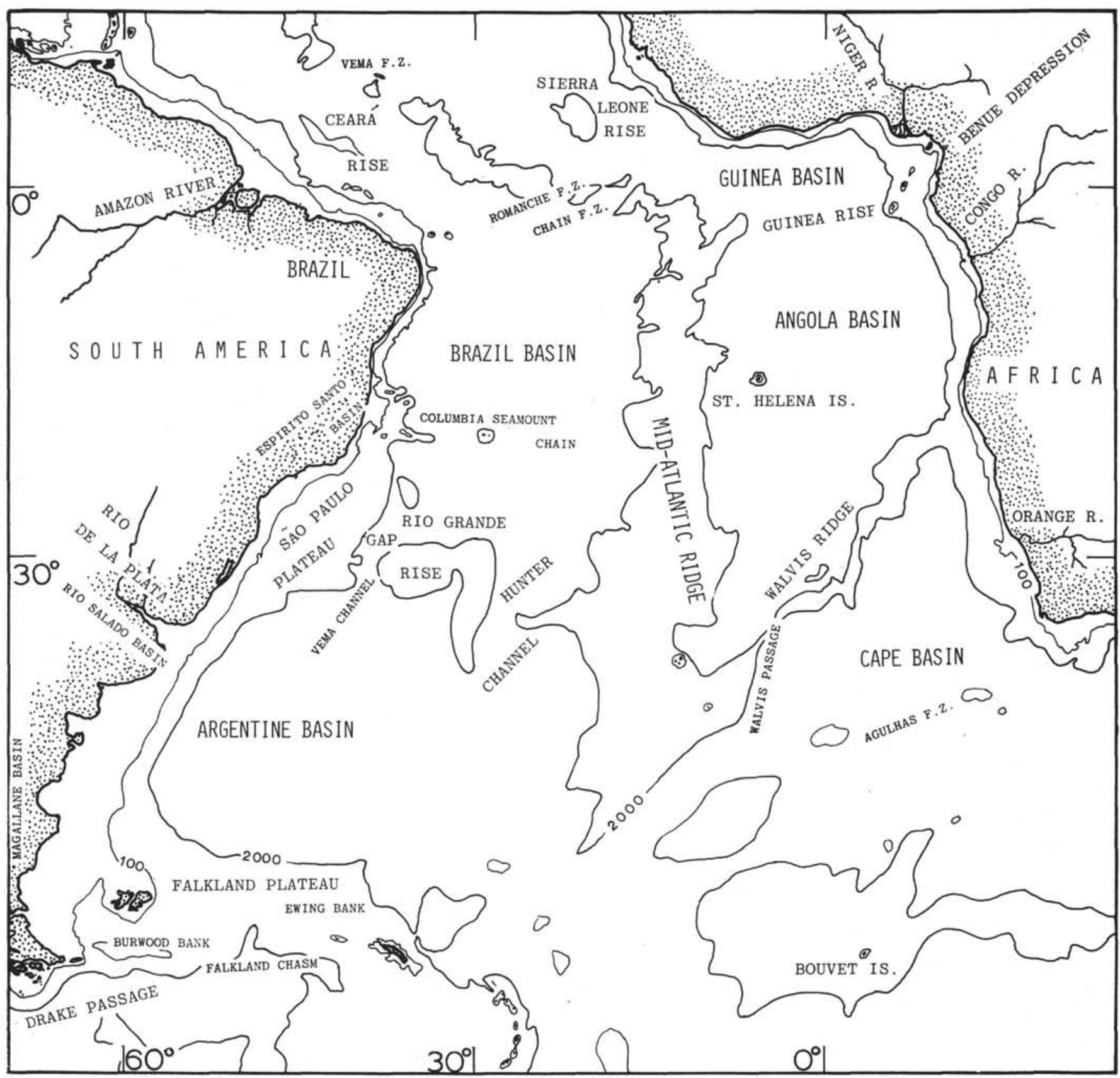

Figure 1. Index chart of the South Atlantic.

South Atlantic, but data from these were not available for this study; they will be incorporated in a later, revised sediment lithofacies summary. A detailed stratigraphy can be assembled from the 28 sites, but because most of them are separated by large distances, horizontal control and lithologic continuity are difficult to establish. Clearly, additional sampling control is needed. Primarily, we have used the extensive collection of piston cores and dredges at the Lamont-Doherty Geological Observatory (L-DGO) for this purpose. For two decades L-DGO has actively sampled the world's oceans, using the Atlantis, Vema, and Conrad; at this writing, the collection contains 322 samples of pre-
Pleistocene sediments from the South Atlantic Ocean. In addition, Woods Hole Oceanographic Institution (WHOI), Florida State University (FSU), and the Centre Oceanologique de Bretagne, using, respectively, the Chain, Eltanin, and Jean Charcot, have conducted sampling programs in the South Atlantic which produced an additional 29 cores or dredges of prePleistocene sediments. Together, these provide over 350 data points and reasonably adequate control for a preliminary correlation between the 28 DSDP sites (Plate 1; Plates 1-6 in back pocket).

Other data exists that could not be incorporated here because of proprietary constraints or because advance 
publication of the information would infringe upon studies in progress. Within the past year, for example, the Islas Orcadas (the former Eltanin) has been used in a study of pre-Pleistocene sediment on the Falkland Plateau and in the southeastern part of the Argentine Basin. Coring and dredging here will add considerably to coverage in this area; we have included some of the tentative results from this cruise, but individual data points are not plotted. Samples dated as pre-Pleistocene were also obtained during the original Challenger expedition; the Scripps Institution of Oceanography has collected similar samples; some older sediments were collected during the Albatross expedition. All of these are described by Funnel (1971), and will be available for incorporation in an up-dated subsequent version.

All the data available at this writing were used to compile maps depicting surface sediment distributions in the South Atlantic since the Early Cretaceous. We have chosen seven time-slices by epochs: Early Cretaceous (all sediments of Albian age or older), Late Cretaceous (sediments dated as Cenomanian through Maestrichtian), Paleocene, Eocene, Oligocene, Miocene, and Pliocene. Even with what appear to be a large store of data, coverage is still not adequate to construct such maps at a closer time interval. Within each of these epochs, a number of physiographic, oceanographic, or climatic changes may have occurred, and our choice of time-slices must necessarily blur some of these changes. Still, the seven maps presented here contain relevant information on the major variations in sediment distribution through time, and their relationship to changing sea-floor physiography, ocean currents, terrigenous sediment influx, carbonate compensation depth, and biological productivity as this ocean evolved.

It must be emphasized again that there are areas and epochs where only a first approximation is feasible. Data are still inadequate for the southeastern portion of the South Atlantic (Cape Basin area), portions of the Argentine Basin and Scotia Island Arc area, and in the Angola Basin. Coverage is good for the Pliocene and Miocene, as might be expected for these stratigraphically youngest sediments, but decreases significantly back to the Early Cretaceous. These maps, then, also offer a guide to future sampling programs in the South Atlantic.

Sample locations (Plate I), sediment paleolithofacies maps (Plate II), carbonate distribution maps (Plate III), and maps showing the distribution of foraminifers and calcareous nannofossils (Plates IV and V) are in the back pocket. Maps giving zeolite distribution are presented in McCoy et al. (this volume). Piston-core and dredge samples used for this compilation are listed in Table 1.

\section{Base Maps}

Palinspastic base maps for each epoch were made by removing successively older time strips from the generalized chart of Pitman et al. (1974), which shows ages of ocean basins from magnetic anomaly lineations. Each map was then refit, holding Africa at its present position. This produced an approximation of continental separation and ocean basin configuration for each epoch. Our reconstructions show physiography at the end of each epoch. For the late Cretaceous, we have used the 105 m.y. configuration given by Leyden et al. (1976), which is based upon the boundaries of evaporite deposits. Note that modern continental outlines are shown on all maps; this may be somewhat misleading, but is used here for convenience.

The 2000-fathom (3660-meter) contour line was chosen simply to provide a clear portrayal of major physiographic features such as the Walvis Ridge and Rio Grande Rise without topographic complexities. This contour is not extended along the Mid-Atlantic Ridge because of the ambiguity in determinations of paleodepth. Note that the trace of this contour on all maps represents the modern topography. Continuity of the Rio Grande Rise and the Sierra Leone Rise with the Mid-Atlantic Ridge (through the Oligocene) has been inferred here by the overlapping of the modern ridge depth with the position of the 2000 -fathom contour line on the rises. Similarly, the shape of the Early Cretaceous basin has been inferred from the closure of the modern trace of this contour line in the vicinity of the Walvis Ridge-Rio Grande Rise area.

Heavy black dashed lines represent the axial trace of the ridge, approximated from our reconstruction of the map of basin ages (Pitman et al., 1974). Complexities in ridge topography, such as fracture zones, flanking seamounts, and the trough system west of the Bouvet triple junction, are not shown both for the sake of clarity and because the available data do not permit a reasonable reconstruction through time. For convenience, modern coastlines are portrayed without regard for changes in sea level, tectonic modifications, or alterations in drainage networks. Thus, for example, the Early Cretaceous map suggests an open seaway between the North and South Atlantic, which did not exist according to a number of studies (Stonely, 1966; Wright, 1968; Reyment, 1969; Premoli-Silva and Boersma, this volume). Modern drainage networks have been depicted back to the Miocene, although, with the possible exception of the Amazon (Damuth, 1973), many of these river systems may be considerably older. Also, the complete separation between South America and Antarctica is depicted in all time slices. Although some evidence now suggests that the Drake Passage did not exist until Anomaly 10 time or about the late Oligocene ( $\mathrm{La}$ Brecque, in preparation), numerous other reconstructions imply considerably earlier seaways here, as for example in the late JurassicCretaceous (e.g., Barker, Dalziel, et al., 1977; Suarez, 1976). Similarly, islands may have existed on both the Rio Grande Rise (Site 357 Site Report, this volume; Thiede, in press), and on the Walvis Ridge.

These base maps thus outline only major first-order topographic sea floor features. Other features, such as fracture zones, undoubtedly have some effect on sedimentation patterns, but as noted in the previous section, the data available now do not warrant their delineation and portrayal. A map for the Jurassic time slice is not attempted because of the paucity of data; to 
TABLE 1

Piston Core and Dredge Samples Studied

\begin{tabular}{|c|c|c|c|c|c|c|}
\hline $\begin{array}{l}\text { Core/Dredge } \\
\text { Number }\end{array}$ & Latitude & Longitude & $\begin{array}{c}\text { Water } \\
\text { Depth } \\
\text { (corrected) } \\
\text { (in m) }\end{array}$ & $\begin{array}{l}\text { Sample } \\
\text { Depth } \\
\text { in Core } \\
(\mathrm{cm})\end{array}$ & Remarks & Reference $^{\mathrm{a}}$ \\
\hline \multicolumn{7}{|l|}{ Cretaceous } \\
\hline $\begin{array}{l}\text { V12-47 } \\
\text { V12-65 } \\
\text { V17-144 } \\
\text { V18-105 } \\
\text { V18-129 } \\
\text { V19-253 } \\
\text { V22-64 } \\
\text { V24-251 } \\
\text { V26-62 } \\
\text { V29-125 }\end{array}$ & $\begin{array}{l}47^{\circ} 54^{\prime} \mathrm{S} \\
22^{\circ} 59^{\prime} \mathrm{S} \\
40^{\circ} 34^{\prime} \mathrm{S} \\
53^{\circ} 23^{\prime} \mathrm{S} \\
41^{\circ} 42^{\prime} \mathrm{S} \\
23^{\circ} 28^{\prime} \mathrm{S} \\
28^{\circ} 34^{\prime} \mathrm{S} \\
30^{\circ} 08^{\prime} \mathrm{S} \\
28^{\circ} 27^{\prime} \mathrm{S} \\
28^{\circ} 12^{\prime} \mathrm{S}\end{array}$ & $\begin{array}{l}59^{\circ} 22^{\prime} \mathrm{W} \\
08^{\circ} 07^{\prime} \mathrm{E} \\
55^{\circ} 10^{\prime} \mathrm{W} \\
50^{\circ} 31^{\prime} \mathrm{W} \\
56^{\circ} 35^{\prime} \mathrm{W} \\
07^{\circ} 07^{\prime} \mathrm{E} \\
30^{\circ} 34^{\prime} \mathrm{W} \\
39^{\circ} 28^{\prime} \mathrm{W} \\
30^{\circ} 28^{\prime} \mathrm{W} \\
02^{\circ} 45^{\prime} \mathrm{E}\end{array}$ & $\begin{array}{r}935 \\
4118 \\
2503 \\
534 \\
2039 \\
4197 \\
2273 \\
4111 \\
3799 \\
3129\end{array}$ & $\begin{array}{r}35 \\
970 \\
440 \\
210 \\
459 \\
485 \\
279 \\
382 \\
150 \\
355\end{array}$ & $\begin{array}{l}\text { Maestrichtian } \\
\text { Maestrichtian } \\
\text { Maestrichtian } \\
\text { Maestrichtian } \\
\text { Maestrichtian } \\
\\
\text { Maestrichtian } \\
\text { Maestrichtian } \\
\text { Maestrichtian } \\
\text { Maestrichtian- } \\
\text { Campanian (?) }\end{array}$ & $\begin{array}{l}(1) \\
(1,19,20) \\
(1,2,21) \\
(1,2) \\
(1,2,21) \\
(1) \\
(1,3) \\
(1,2) \\
(1,3) \\
(4)\end{array}$ \\
\hline $\begin{array}{l}\text { V31-7 } \\
\text { V31-55 }\end{array}$ & $\begin{array}{l}28^{\circ} 13^{\prime} \mathrm{S} \\
45^{\circ} 27^{\prime} \mathrm{S}\end{array}$ & $\begin{array}{l}31^{\circ} 42^{\prime} \mathrm{W} \\
58^{\circ} 55^{\prime} \mathrm{W}\end{array}$ & $\begin{array}{l}4569 \\
1814\end{array}$ & $\begin{array}{r}365 \\
53\end{array}$ & $\begin{array}{l}\text { Campanian } \\
\text { Santonian- } \\
\text { Campanian }\end{array}$ & $\begin{array}{l}(5) \\
(6)\end{array}$ \\
\hline $\begin{array}{l}\text { Paleocene } \\
\begin{array}{l}\text { V31-115 } \\
\text { RC16-94 } \\
\text { V22-140 } \\
\text { V22-145 } \\
\text { V24-243 } \\
\text { V26-65 } \\
\text { V26-81 } \\
\text { V29-124 } \\
\text { V29-134 }\end{array}\end{array}$ & $\begin{array}{l}22^{\circ} 58^{\prime} \mathrm{S} \\
46^{\circ} 21^{\prime} \mathrm{S} \\
33^{\circ} 37^{\prime} \mathrm{S} \\
32^{\circ} 22^{\prime} \mathrm{S} \\
31^{\circ} 02^{\prime} \mathrm{S} \\
26^{\circ} 42^{\prime} \mathrm{S} \\
23^{\circ} 46^{\prime} \mathrm{S} \\
28^{\circ} 12^{\prime} \mathrm{S} \\
24^{\circ} 13^{\prime} \mathrm{S}\end{array}$ & $\begin{array}{l}38^{\circ} 21^{\prime} \mathrm{W} \\
59^{\circ} 32^{\prime} \mathrm{W} \\
02^{\circ} 21^{\prime} \mathrm{E} \\
02^{\circ} 09^{\prime} \mathrm{E} \\
35^{\circ} 43^{\prime} \mathrm{W} \\
27^{\circ} 52^{\prime} \mathrm{W} \\
34^{\circ} 22^{\prime} \mathrm{W} \\
02^{\circ} 45^{\prime} \mathrm{E} \\
07^{\circ} 25^{\prime} \mathrm{E}\end{array}$ & $\begin{array}{l}3367 \\
1028 \\
4433 \\
2056 \\
1020 \\
4371 \\
4387 \\
3063 \\
3804\end{array}$ & $\begin{array}{l}680 \\
440 \\
295 \\
415 \\
\\
225 \\
985 \\
795 \\
683\end{array}$ & Campanian & $\begin{array}{l}(5) \\
(4) \\
(1) \\
(1) \\
(1) \\
(1,22) \\
(1) \\
(4) \\
(4)\end{array}$ \\
\hline \multicolumn{7}{|l|}{ Eocene } \\
\hline $\begin{array}{l}\text { C115-70 } \\
\text { E6-8 } \\
\text { E6-9 } \\
\text { RC-2 } \\
\text { RC11-25 } \\
\text { RC12-237 } \\
\text { RC12-242 } \\
\text { RC15-84 } \\
\text { RC15-85 } \\
\text { RC15-121 } \\
\text { V12-40 } \\
\text { V12-46 } \\
\text { V17-1-7 } \\
\text { V18-RD29 }\end{array}$ & $\begin{array}{l}29^{\circ} 55^{\prime} \mathrm{S} \\
53^{\circ} 01^{\prime} \mathrm{S} \\
53^{\circ} 60^{\prime} \mathrm{S} \\
11^{\circ} 12^{\prime} \mathrm{N} \\
28^{\circ} 33.4^{\prime} \mathrm{S} \\
47^{\circ} 46^{\prime} \mathrm{S} \\
43^{\circ} 28^{\prime} \mathrm{S} \\
50^{\circ} 28^{\prime} \mathrm{S} \\
50^{\circ} 38^{\prime} \mathrm{S} \\
49^{\circ} 37^{\prime} \mathrm{S} \\
45^{\circ} 28^{\prime} \mathrm{S} \\
47^{\circ} 28^{\prime} \mathrm{S} \\
51^{\circ} 08^{\prime} \mathrm{S} \\
55^{\circ} 29^{\prime} \mathrm{S}\end{array}$ & $\begin{array}{l}35^{\circ} 39^{\prime} \mathrm{W} \\
55^{\circ} 48^{\prime} \mathrm{W} \\
55^{\circ} 58^{\prime} \mathrm{W} \\
48^{\circ} 05^{\prime} \mathrm{W} \\
30^{\circ} 03^{\prime} \mathrm{W} \\
57^{\circ} 39^{\prime} \mathrm{W} \\
57^{\circ} 40^{\prime} \mathrm{W} \\
44^{\circ} 43^{\prime} \mathrm{W} \\
40^{\circ} 21^{\prime} \mathrm{W} \\
55^{\circ} 54^{\prime} \mathrm{W} \\
59^{\circ} 40^{\prime} \mathrm{W} \\
59^{\circ} 21^{\prime} \mathrm{W} \\
54^{\circ} 22^{\prime} \mathrm{W} \\
65^{\circ} 57^{\prime} \mathrm{W}\end{array}$ & $\begin{array}{r}2272 \\
1992 \\
1800 \\
4625 \\
1842 \\
3652 \\
3638 \\
1492 \\
3085 \\
739 \\
1044 \\
1167 \\
1525 \\
1966- \\
1719\end{array}$ & $\begin{array}{l}286 \\
150 \\
750 \\
730 \\
440 \\
210 \\
555 \\
143 \\
170 \\
245 \\
712 \\
245 \\
-\end{array}$ & & $\begin{array}{l}(7) \\
(1) \\
(1) \\
) 1- \\
(1) \\
(1) \\
(1) \\
(4) \\
(4) \\
(4) \\
(2,21) \\
(1,21) \\
(1,18) \\
(1)\end{array}$ \\
\hline $\begin{array}{l}\text { V18-104 } \\
\text { V18-112 } \\
\text { V18-130 } \\
\text { V18-145 } \\
\text { V20-220 } \\
\text { V22-50 } \\
\text { V22-51 } \\
\text { V22-52 } \\
\text { V22-54 } \\
\text { V22-148 } \\
\text { V22-149 } \\
\text { V24-222 } \\
\text { V24-225 } \\
\text { V24-237 } \\
\text { V26-66 } \\
\text { V29-117 } \\
\text { V29-129 } \\
\text { V29-130 } \\
\text { V29-131 }\end{array}$ & $\begin{array}{l}53^{\circ} 01^{\prime} \mathrm{S} \\
51^{\circ} 40^{\prime} \mathrm{S} \\
41^{\circ} 30^{\prime} \mathrm{S} \\
41^{\circ} 30^{\prime} \mathrm{S} \\
28^{\circ} 36^{\prime} \mathrm{S} \\
28^{\circ} 32^{\prime} \mathrm{S} \\
28^{\circ} 32^{\prime} \mathrm{S} \\
28^{\circ} 32^{\prime} \mathrm{S} \\
28^{\circ} 30^{\prime} \mathrm{S} \\
32^{\circ} 20^{\prime} \mathrm{S} \\
31^{\circ} 26^{\prime} \mathrm{S} \\
32^{\circ} 59^{\prime} \mathrm{S} \\
34^{\circ} 54^{\prime} \mathrm{S} \\
32^{\circ} 12^{\prime} \mathrm{S} \\
29^{\circ} 27^{\prime} \mathrm{S} \\
33^{\circ} 11^{\prime} \mathrm{S} \\
26^{\circ} 12^{\prime} \mathrm{S} \\
24^{\circ} 42^{\prime} \mathrm{S} \\
24^{\circ} 42^{\prime} \mathrm{S}\end{array}$ & $\begin{array}{l}52^{\circ} 52^{\prime} \mathrm{W} \\
48^{\circ} 29^{\prime} \mathrm{W} \\
56^{\circ} 37^{\prime} \mathrm{W} \\
53^{\circ} 17^{\prime} \mathrm{W} \\
29^{\circ} 01^{\prime} \mathrm{W} \\
29^{\circ} 00^{\prime} \mathrm{W} \\
29^{\circ} 00^{\prime} \mathrm{W} \\
29^{\circ} 00^{\prime} \mathrm{W} \\
28^{\circ} 58^{\prime} \mathrm{W} \\
02^{\circ} 10^{\prime} \mathrm{E} \\
00^{\circ} 50^{\prime} \mathrm{E} \\
03^{\circ} 02^{\prime} \mathrm{W} \\
04^{\circ} 57^{\prime} \mathrm{W} \\
26^{\circ} 44^{\prime} \mathrm{W} \\
21^{\circ} 51^{\prime} \mathrm{W} \\
02^{\circ} 58^{\prime} \mathrm{W} \\
05^{\circ} 50^{\prime} \mathrm{E} \\
06^{\circ} 30^{\prime} \mathrm{E} \\
06^{\circ} 30^{\prime} \mathrm{E}\end{array}$ & $\begin{array}{r}2880 \\
2429 \\
1415 \\
5649 \\
3601 \\
3566 \\
933 \\
4361 \\
3781 \\
2047 \\
4012 \\
1587 \\
1790 \\
4193 \\
4510 \\
1730 \\
1075 \\
1075 \\
1068\end{array}$ & $\begin{array}{l}330 \\
325 \\
125 \\
490 \\
440 \\
395 \\
810 \\
200 \\
480 \\
522 \\
577 \\
240 \\
710 \\
580 \\
370 \\
616 \\
395 \\
296\end{array}$ & & $\begin{array}{l}(1,18) \\
(1,18) \\
(1,18,21) \\
(8) \\
(1,19,20) \\
(1) \\
(1) \\
(1) \\
(1) \\
(1) \\
(1) \\
(1) \\
(1) \\
(1) \\
(9) \\
(4) \\
(4) \\
(4) \\
(4)\end{array}$ \\
\hline
\end{tabular}


TABLE 1 - Continued

\begin{tabular}{|c|c|c|c|c|c|c|}
\hline $\begin{array}{l}\text { Core/Dredge } \\
\text { Number }\end{array}$ & Latitude & Longitude & $\begin{array}{c}\text { Water } \\
\text { Depth } \\
\text { (corrected), } \\
\text { (in } \mathrm{m} \text { ) }\end{array}$ & $\begin{array}{c}\text { Sample } \\
\text { Depth } \\
\text { in Core } \\
(\mathrm{cm})\end{array}$ & Remarks & Reference $^{\mathrm{a}}$ \\
\hline V31-25 & $43^{\circ} 22^{\prime} \mathrm{S}$ & $58^{\circ} 13^{\prime} \mathrm{W}$ & 2264 & 325 & & (4) \\
\hline V31-101 & $24^{\circ} 47^{\prime} \mathrm{S}$ & $42^{\circ} 02^{\prime} \mathrm{W}$ & 2321 & 875 & & (10) \\
\hline V31-107 & $24^{\circ} 49^{\prime} \mathrm{S}$ & $42^{\circ} 03^{\prime} \mathrm{W}$ & 2294 & 490 & & (10) \\
\hline \multicolumn{7}{|l|}{ Oligocene } \\
\hline C115-45 & $31^{\circ} 31^{\prime} \mathrm{S}$ & $24^{\circ} 26^{\prime} \mathrm{W}$ & 4305 & - & & (11) \\
\hline C115-82 & $29^{\circ} 57^{\prime} \mathrm{S}$ & $35^{\circ} 33^{\prime} \mathrm{W}$ & 2259 & - & & (7) \\
\hline DRO-1 & $29^{\circ} 40^{\prime} \mathrm{S}$ & $36^{\circ} 26^{\prime} \mathrm{W}$ & 2250 & - & & (12) \\
\hline DRO-2 & $29^{\circ} 57^{\prime} \mathrm{S}$ & $36^{\circ} 10^{\prime} \mathrm{W}$ & 1483 & - & & (12) \\
\hline DRO-3 & $30^{\circ} 51^{\prime} \mathrm{S}$ & $36^{\circ} 53^{\prime} \mathrm{W}$ & 1815 & - & & (12) \\
\hline RC12-296 & $37^{\circ} 04^{\prime} \mathrm{S}$ & $07^{\circ} 12^{\prime} \mathrm{W}$ & 2681 & 40 & & (1) \\
\hline RC12-297 & $36^{\circ} 09^{\prime} \mathrm{S}$ & $06^{\circ} 43^{\prime} \mathrm{W}$ & 3528 & 360 & & (1) \\
\hline $\mathrm{RC} 13-247$ & $35^{\circ} 46^{\prime} \mathrm{S}$ & $13^{\circ} 52^{\prime} \mathrm{E}$ & 4832 & 380 & & (13) \\
\hline V9-29 & $03^{\circ} 48^{\prime} \mathrm{N}$ & $34^{\circ} 37^{\prime} \mathrm{W}$ & 4675 & 980 & & (14) \\
\hline V16-33 & $15^{\circ} 20^{\prime} \mathrm{S}$ & $19^{\circ} 43^{\prime} \mathrm{W}$ & 4360 & 660 & & (1) \\
\hline $\mathrm{V} 20-220$ & $28^{\circ} 36^{\prime} \mathrm{S}$ & $29^{\circ} 01^{\prime} \mathrm{W}$ & 3601 & 435 & & (1) \\
\hline V22-57 & $28^{\circ} 31^{\prime} \mathrm{S}$ & $29^{\circ} 08^{\prime} \mathrm{W}$ & 3299 & 445 & & (1) \\
\hline V22-187 & $04^{\circ} 26^{\prime} \mathrm{N}$ & $20^{\circ} 48^{\prime} \mathrm{W}$ & 3394 & 980 & & (1) \\
\hline V26-59 & $28^{\circ} 34^{\prime} \mathrm{S}$ & $30^{\circ} 33^{\prime} \mathrm{W}$ & 2338 & 230 & & (1) \\
\hline V26-66 & $29^{\circ} 27^{\prime} \mathrm{S}$ & $21^{\circ} 51^{\prime} \mathrm{W}$ & 4510 & 400 & & (1) \\
\hline V27-RD23 & $27^{\circ} 52^{\prime} \mathrm{S}$ & $03^{\circ} 14^{\prime} \mathrm{E}$ & 1675 & - & & (1) \\
\hline \multicolumn{7}{|l|}{ Miocene } \\
\hline A180-99 & $16^{\circ} 14^{\prime} \mathrm{S}$ & $35^{\circ} 21^{\prime} \mathrm{W}$ & 4206 & 490 & & (1) \\
\hline C115-64 & $30^{\circ} 00^{\prime} \mathrm{S}$ & $35^{\circ} 34^{\prime} \mathrm{W}$ & 2029 & - & & (7) \\
\hline C115-67 & $29^{\circ} 58^{\prime} \mathrm{S}$ & $35^{\circ} 34^{\prime} \mathrm{W}$ & 2189 & - & & (7) \\
\hline C115-73 & $29^{\circ} 59^{\prime} \mathrm{S}$ & $35^{\circ} 34^{\prime} \mathrm{W}$ & 2138 & - & & (7) \\
\hline C115-75 & $29^{\circ} 59^{\prime} \mathrm{S}$ & $35^{\circ} 33^{\prime} \mathrm{W}$ & 2222 & - & & (7) \\
\hline C115-79 & $29^{\circ} 58^{\prime} \mathrm{S}$ & $35^{\circ} 34^{\prime} \mathrm{W}$ & 2214 & - & & (7) \\
\hline C115-81 & $29^{\circ} 58^{\prime} \mathrm{S}$ & $35^{\circ} 35^{\prime} \mathrm{W}$ & 2270 & - & & (7) \\
\hline C115-86 & $29^{\circ} 58^{\prime} \mathrm{S}$ & $35^{\circ} 34^{\prime} \mathrm{W}$ & 2112 & - & & (7) \\
\hline DRO-5 & $31^{\circ} 48^{\prime} \mathrm{S}$ & $37^{\circ} 31^{\prime} \mathrm{W}$ & 3221 & - & & (12) \\
\hline E6-10 & $55^{\circ} 06^{\prime} \mathrm{S}$ & $55^{\circ} 35^{\prime} \mathrm{W}$ & 2251 & 225 & & (1) \\
\hline E9-2 & $50^{\circ} 37^{\prime} \mathrm{S}$ & $43^{\circ} 46^{\prime} \mathrm{W}$ & 2375 & 541 & & (1) \\
\hline E9-3 & $50^{\circ} 36^{\prime} \mathrm{S}$ & $43^{\circ} 43^{\prime} \mathrm{W}$ & 2357 & 445 & & (1) \\
\hline E9-4 & $49^{\circ} 50^{\prime} \mathrm{S}$ & $39^{\circ} 56^{\prime} \mathrm{W}$ & 5721 & 948 & & (1) \\
\hline E22-10 & $50^{\circ} 59^{\prime} \mathrm{S}$ & $46^{\circ} 06^{\prime} \mathrm{W}$ & 3956 & 180 & & (1) \\
\hline RC11-27 & $28^{\circ} 31^{\prime} \mathrm{S}$ & $30^{\circ} 04^{\prime} \mathrm{W}$ & 2704 & 36 & & (1) \\
\hline RC11-30 & $28^{\circ} 21^{\prime} \mathrm{S}$ & $31^{\circ} 04^{\prime} \mathrm{W}$ & 2479 & 640 & & (1) \\
\hline RC11-31 & $28^{\circ} 21^{\prime} \mathrm{S}$ & $31^{\circ} 04^{\prime} \mathrm{W}$ & 2481 & 830 & & (1) \\
\hline RC11-88 & $41^{\circ} 11^{\prime} \mathrm{S}$ & $20^{\circ} 08^{\prime} \mathrm{E}$ & 5125 & 742 & & (1) \\
\hline RC12-249 & $38^{\circ} 24^{\prime} \mathrm{S}$ & $54^{\circ} 34^{\prime} \mathrm{W}$ & 1196 & 160 & & (4) \\
\hline $\mathrm{RC} 13-247$ & $35^{\circ} 46^{\prime} \mathrm{S}$ & $13^{\circ} 52^{\prime} \mathrm{E}$ & 4832 & 380 & & (13) \\
\hline $\mathrm{RC} 13-270$ & $55^{\circ} 29^{\prime} \mathrm{S}$ & $04^{\circ} 38^{\prime} \mathrm{E}$ & 3160 & 2205 & & (15) \\
\hline $\mathrm{RC} 13-272$ & $55^{\circ} 05^{\prime} \mathrm{S}$ & $08^{\circ} 00^{\prime} \mathrm{E}$ & 2538 & 1105 & & (15) \\
\hline RC13-274 & $53^{\circ} 09^{\prime} \mathrm{S}$ & $12^{\circ} 26^{\prime} \mathrm{E}$ & 3372 & 983 & & (15) \\
\hline RC15-97 & $42^{\circ} 57^{\prime} \mathrm{S}$ & $26^{\circ} 56^{\prime} \mathrm{W}$ & 4583 & 882 & & (8) \\
\hline RC15-107 & $41^{\circ} 24^{\prime} \mathrm{S}$ & $50^{\circ} 59^{\prime} \mathrm{W}$ & 5018 & 440 & & (17) \\
\hline V9-2 & $01^{\circ} 46^{\prime} \mathrm{S}$ & $35^{\circ} 39^{\prime} \mathrm{W}$ & 3115 & 360 & & (1) \\
\hline V9-6 & $03^{\circ} 51^{\prime} \mathrm{S}$ & $34^{\circ} 41^{\prime} \mathrm{W}$ & 1139 & 490 & & (1) \\
\hline V9-18 & $08^{\circ} 59^{\prime} \mathrm{S}$ & $15^{\circ} 55^{\prime} \mathrm{W}$ & 4005 & 122 & & (1) \\
\hline V12-19 & $29^{\circ} 52^{\prime} \mathrm{S}$ & $36^{\circ} 48^{\prime} \mathrm{W}$ & 2321 & 181 & & $(1,19,20)$ \\
\hline V12-42 & $45^{\circ} 27^{\prime} \mathrm{S}$ & $58^{\circ} 08^{\prime} \mathrm{W}$ & 3266 & 77 & & (1) \\
\hline V12-48 & $46^{\circ} 47^{\prime} \mathrm{S}$ & $58^{\circ} 12^{\prime} \mathrm{W}$ & 2763 & 665 & & $(1,21)$ \\
\hline V14-44 & $53^{\circ} 29^{\prime} \mathrm{S}$ & $58^{\circ} 31^{\prime} \mathrm{W}$ & 2140 & 245 & & (1) \\
\hline V14-47 & $50^{\circ} 47^{\prime} \mathrm{S}$ & $42^{\circ} 09^{\prime} \mathrm{W}$ & 1690 & 490 & & (1) \\
\hline V15-96 & $53^{\circ} 16^{\prime} \mathrm{S}$ & $68^{\circ} 10^{\prime} \mathrm{W}$ & 11 & 212 & & (1) \\
\hline V15-125 & $55^{\circ} 18^{\prime} \mathrm{S}$ & $64^{\circ} 09^{\prime} \mathrm{W}$ & 3263 & 715 & & (1) \\
\hline V15-136 & $52^{\circ} 11^{\prime} \mathrm{S}$ & $49^{\circ} 05^{\prime} \mathrm{W}$ & 2514 & 735 & & (1) \\
\hline V18-97 & $55^{\circ} 43^{\prime} \mathrm{S}$ & $59^{\circ} 06^{\prime} \mathrm{W}$ & 3892 & 463 & & (1) \\
\hline V18-106 & $53^{\circ} 27^{\prime} \mathrm{S}$ & $50^{\circ} 24^{\prime} \mathrm{W}$ & 2638 & 240 & & (1) \\
\hline V18-107 & $52^{\circ} 54^{\prime} \mathrm{S}$ & $48^{\circ} 08^{\prime} \mathrm{W}$ & 2926 & 442 & & (1) \\
\hline V18-109 & $52^{\circ} 12^{\prime} \mathrm{S}$ & $45^{\circ} 42^{\prime} \mathrm{W}$ & 3232 & 320 & & (1) \\
\hline V18-114 & $49^{\circ} 35^{\prime} \mathrm{S}$ & $50^{\circ} 34^{\prime} \mathrm{W}$ & 2576 & 490 & & (1) \\
\hline V18-115 & $49^{\circ} 26^{\prime} \mathrm{S}$ & $50^{\circ} 42^{\prime} \mathrm{W}$ & 3493 & 82 & & (1) \\
\hline
\end{tabular}


TABLE 1 - Continued

\begin{tabular}{|c|c|c|c|c|c|c|}
\hline $\begin{array}{l}\text { Core/Dredge } \\
\text { Number }\end{array}$ & Latitude & Longitude & $\begin{array}{c}\text { Water } \\
\text { Depth } \\
\text { (corrected), } \\
\text { (in m) }\end{array}$ & $\begin{array}{l}\text { Sample } \\
\text { Depth } \\
\text { in Core } \\
(\mathrm{cm})\end{array}$ & Remarks & Reference $^{\mathrm{a}}$ \\
\hline V18-116 & $49^{\circ} 26^{\prime} S$ & $50^{\circ} 28^{\prime} \mathrm{W}$ & 2367 & 185 & & (1) \\
\hline V18-117 & $49^{\circ} 30^{\prime} \mathrm{S}$ & $52^{\circ} 15^{\prime} \mathrm{W}$ & 2559 & 245 & & (1) \\
\hline V18-118 & $49^{\circ} 05^{\prime} \mathrm{S}$ & $52^{\circ} 43^{\prime} \mathrm{W}$ & 5319 & 1100 & & (1) \\
\hline V18-121 & $47^{\circ} 37^{\prime} \mathrm{S}$ & $55^{\circ} 29^{\prime} \mathrm{W}$ & 5236 & 538 & & $(1,21)$ \\
\hline V18-128 & $44^{\circ} 21^{\prime} \mathrm{S}$ & $57^{\circ} 21^{\prime} \mathrm{W}$ & 4333 & 483 & & $(1,21)$ \\
\hline V18-RD9 & $55^{\circ} 29^{\prime} \mathrm{S}$ & $65^{\circ} 57^{\prime} \mathrm{W}$ & $\begin{array}{l}1966 \\
1719\end{array}$ & $\cdots$ & & (1) \\
\hline V18-RD14 & $44^{\circ} 21^{\prime} \mathrm{S}$ & $57^{\circ} 21^{\prime} \mathrm{W}$ & $\begin{array}{l}4605 \\
4298\end{array}$ & $\cdots$ & & (1) \\
\hline V19-250 & $24^{\circ} 07^{\prime} \mathrm{S}$ & $05^{\circ} 45^{\prime} \mathrm{E}$ & 1600 & 475 & & $(1,19,20)$ \\
\hline V20-205 & $25^{\circ} 27^{\prime} \mathrm{S}$ & $06^{\circ} 28^{\prime} \mathrm{E}$ & 1626 & 1040 & & $(1,19,20)$ \\
\hline V20-219 & $29^{\circ} 02^{\prime} \mathrm{S}$ & $29^{\circ} 13^{\prime} \mathrm{W}$ & 3092 & 468 & & $(1,19,20)$ \\
\hline V22-58 & $28^{\circ} 37^{\prime} \mathrm{S}$ & $29^{\circ} 08^{\prime} \mathrm{W}$ & 3442 & 581 & & (1) \\
\hline V22-63 & $28^{\circ} 58^{\prime} \mathrm{S}$ & $29^{\circ} 27^{\prime} \mathrm{W}$ & 2722 & 647 & & (1) \\
\hline V22-65 & $28^{\circ} 34^{\prime} \mathrm{S}$ & $30^{\circ} 34^{\prime} \mathrm{W}$ & 2339 & 375 & & (1) \\
\hline V22-67 & $28^{\circ} 34^{\prime} \mathrm{S}$ & $30^{\circ} 34^{\prime} \mathrm{W}$ & 2361 & 350 & & (1) \\
\hline V22-68 & $28^{\circ} 34^{\prime} \mathrm{S}$ & $30^{\circ} 34^{\prime} \mathrm{W}$ & 2274 & 345 & & (1) \\
\hline V22-70 & $28^{\circ} 47^{\prime} \mathrm{S}$ & $32^{\circ} 38^{\prime} \mathrm{W}$ & 2750 & 790 & & (1) \\
\hline V22-71 & $29^{\circ} 35^{\prime} \mathrm{S}$ & $33^{\circ} 25^{\prime} \mathrm{W}$ & 3314 & 995 & & (1) \\
\hline V22-94 & $51^{\circ} 31^{\prime} \mathrm{S}$ & $43^{\circ} 30^{\prime} \mathrm{W}$ & 2164 & 426 & & (1) \\
\hline V22-99 & $49^{\circ} 14^{\prime} \mathrm{S}$ & $33^{\circ} 13^{\prime} \mathrm{W}$ & 5440 & 498 & & (4) \\
\hline V22-106 & $46^{\circ} 08^{\prime} \mathrm{S}$ & $10^{\circ} 54^{\prime} \mathrm{W}$ & 3037 & 965 & & (1) \\
\hline V22-135 & $38^{\circ} 05^{\prime} \mathrm{S}$ & $21^{\circ} 21^{\prime} \mathrm{E}$ & 5115 & 482 & & (1) \\
\hline V22-142 & $33^{\circ} 15^{\prime} \mathrm{S}$ & $01^{\circ} 55^{\prime} \mathrm{E}$ & 4502 & 416 & & (1) \\
\hline V22-146 & $32^{\circ} 21^{\prime} \mathrm{S}$ & $02^{\circ} 10^{\prime} \mathrm{E}$ & 2177 & 138 & & (1) \\
\hline V22-153 & $31^{\circ} 15^{\prime} \mathrm{S}$ & $02^{\circ} 31^{\prime} \mathrm{E}$ & 1721 & 590 & & (1) \\
\hline V22-155 & $31^{\circ} 12^{\prime} \mathrm{S}$ & $02^{\circ} 46^{\prime} \mathrm{E}$ & 1618 & 1225 & & (1) \\
\hline V22-159 & $28^{\circ} 43^{\prime} \mathrm{S}$ & $01^{\circ} 55^{\prime} \mathrm{E}$ & 3471 & 380 & & (1) \\
\hline V22-172 & $12^{\circ} 40^{\prime} \mathrm{S}$ & $09^{\circ} 49^{\prime} \mathrm{W}$ & 4127 & 985 & & (1) \\
\hline V22-178 & $05^{\circ} 01^{\prime} \mathrm{S}$ & $15^{\circ} 39^{\prime} \mathrm{W}$ & 3290 & 245 & & (1) \\
\hline V22-181 & $02^{\circ} 21^{\prime} \mathrm{S}$ & $16^{\circ} 54^{\prime} \mathrm{W}$ & $\begin{array}{l}4012- \\
4438\end{array}$ & 295 & & (1) \\
\hline V22-190 & $06^{\circ} 02^{\prime} \mathrm{N}$ & $21^{\circ} 16^{\prime} \mathrm{W}$ & 3491 & 1110 & & (1) \\
\hline V22-RD10 & $16^{\circ} 03^{\prime} \mathrm{S}$ & $05^{\circ} 50^{\prime} \mathrm{W}$ & $\begin{array}{l}2319- \\
2096\end{array}$ & $\cdots$ & & (1) \\
\hline V25-53 & $00^{\circ} 31^{\prime} \mathrm{S}$ & $39^{\circ} 17^{\prime} \mathrm{W}$ & 2425 & 525 & & (1) \\
\hline V25-54 & $01^{\circ} 25^{\prime} \mathrm{S}$ & $37^{\circ} 23^{\prime} \mathrm{W}$ & 3056 & 490 & & (1) \\
\hline V25-55 & $01^{\circ} 54^{\prime} \mathrm{S}$ & $37^{\circ} 09^{\prime} \mathrm{W}$ & 2012 & 1070 & & (1) \\
\hline V25-59 & $01^{\circ} 22^{\prime} \mathrm{N}$ & $33^{\circ} 29^{\prime} \mathrm{W}$ & 3824 & 840 & & (14) \\
\hline V25-62 & $03^{\circ} 25^{\prime} \mathrm{N}$ & $39^{\circ} 41^{\prime} \mathrm{W}$ & 4321 & 345 & & (1) \\
\hline V26-68 & $30^{\circ} 21^{\prime} \mathrm{S}$ & $15^{\circ} 48^{\prime} \mathrm{W}$ & 3233 & 442 & & (1) \\
\hline V29-120 & $29^{\circ} 50^{\prime} \mathrm{S}$ & $02^{\circ} 38^{\prime} \mathrm{E}$ & 1805 & 387 & & (4) \\
\hline V29-126 & $26^{\circ} 20^{\prime} \mathrm{S}$ & $05^{\circ} 34^{\prime} \mathrm{E}$ & 1611 & 799 & & (4) \\
\hline V31-101 & $24^{\circ} 47^{\prime} \mathrm{S}$ & $42^{\circ} 02^{\prime} \mathrm{W}$ & 2321 & 5 & & (10) \\
\hline V31-112 & $25^{\circ} 07^{\prime} \mathrm{S}$ & $41^{\circ} 50^{\prime} \mathrm{W}$ & 2573 & 260 & & (4) \\
\hline \multicolumn{7}{|l|}{ Pliocene } \\
\hline A180-107 & $19^{\circ} 39^{\prime} \mathrm{S}$ & $36^{\circ} 04^{\prime} \mathrm{S}$ & 4023 & 368 & & (1) \\
\hline A180-113 & $20^{\circ} 37^{\prime} \mathrm{S}$ & $34^{\circ} 32^{\prime} \mathrm{W}$ & 2651 & 5 & & (1) \\
\hline C99-22 & $08^{\circ} 43^{\prime} \mathrm{S}$ & $06^{\circ} 26^{\prime} \mathrm{W}$ & 4660 & 509 & & (16) \\
\hline C99-32 & $08^{\circ} 41^{\prime} S$ & $11^{\circ} 50^{\prime} \mathrm{E}$ & 1945 & 330 & & (16) \\
\hline C115-76 & $29^{\circ} 56^{\prime} \mathrm{S}$ & $35^{\circ} 33^{\prime} \mathrm{W}$ & 2315 & $\cdots$ & & (11) \\
\hline C115-84 & $30^{\circ} 00^{\prime} \mathrm{S}$ & $35^{\circ} 35^{\prime} \mathrm{W}$ & $? 110$ & $\cdots$ & & (7) \\
\hline E6-6 & $57^{\circ} 10^{\prime} \mathrm{S}$ & $58^{\circ} 50^{\prime} \mathrm{W}$ & 3710 & 514 & & (I) \\
\hline E6-11 & $55^{\circ} 44^{\prime} \mathrm{S}$ & $56^{\circ} 03^{\prime} \mathrm{W}$ & 3980 & 541 & & (1) \\
\hline E7-3 & $55^{\circ} 03^{\prime} \mathrm{S}$ & $44^{\circ} 40^{\prime} \mathrm{W}$ & 3553 & 493 & & (1) \\
\hline E8-18 & $58^{\circ} 31^{\prime} \mathrm{S}$ & $22^{\circ} 24^{\prime} \mathrm{W}$ & 4557 & 965 & & (1) \\
\hline RC8-15 & $19^{\circ} 21^{\prime} \mathrm{S}$ & $20^{\circ} 32^{\prime} \mathrm{W}$ & 4707 & 671 & & (1) \\
\hline RC8-17 & $23^{\circ} 50$ 's & $15^{\circ} 36^{\prime} \mathrm{W}$ & 4235 & 570 & & (1) \\
\hline RC8-20 & $24^{\circ} 31^{\prime} \mathrm{S}$ & $14^{\circ} 13^{\prime} \mathrm{W}$ & 3446 & 20 & & (1) \\
\hline $\mathrm{RC} 11-33$ & $30^{\circ} 58^{\prime} \mathrm{S}$ & $31^{\circ} 37^{\prime} \mathrm{W}$ & 3252 & 1160 & & (1) \\
\hline RC11-47 & $43^{\circ} 21^{\prime} \mathrm{S}$ & $38^{\circ} 39^{\prime} \mathrm{W}$ & 5201 & 1360 & & (8) \\
\hline RC11-72 & $48^{\circ} 51^{\prime} \mathrm{S}$ & $30^{\circ} 52^{\prime} \mathrm{W}$ & 5561 & 1202 & & (1) \\
\hline RC11-81 & $48^{\circ} 54^{\prime} \mathrm{S}$ & $05^{\circ} 13^{\prime} \mathrm{E}$ & 4704 & 610 & & (8) \\
\hline RC11-82 & $43^{\circ} 29^{\prime} \mathrm{S}$ & $05^{\circ} 57^{\prime} \mathrm{E}$ & 4609 & 975 & & (8) \\
\hline $\mathrm{RC} 12-241$ & $43^{\circ} 38^{\prime} \mathrm{S}$ & $57^{\circ} 40^{\prime} \mathrm{W}$ & 3499 & 600 & & (1) \\
\hline
\end{tabular}


TABLE 1 - Continued

\begin{tabular}{|c|c|c|c|c|c|c|}
\hline $\begin{array}{l}\text { Core/Dredge } \\
\text { Number }\end{array}$ & Latitude & Longitude & $\begin{array}{c}\text { Water } \\
\text { Depth } \\
\text { (corrected), } \\
\text { (in } \mathrm{m} \text { ) }\end{array}$ & $\begin{array}{c}\text { Sample } \\
\text { Depth } \\
\text { in Core } \\
(\mathrm{cm})\end{array}$ & Remarks & Reference $^{a}$ \\
\hline $\mathrm{RC} 12-253$ & $44^{\circ} 10^{\prime} \mathrm{S}$ & $46^{\circ} 31^{\prime} \mathrm{W}$ & 5128 & 1225 & & (17) \\
\hline $\mathrm{RC} 12-254$ & $45^{\circ} 02^{\prime} \mathrm{S}$ & $41^{\circ} 07^{\prime} \mathrm{W}$ & 4786 & 980 & & (8) \\
\hline RC12-264 & $41^{\circ} 01^{\prime} \mathrm{S}$ & $30^{\circ} 17^{\prime} \mathrm{W}$ & 4761 & 737 & & (8) \\
\hline $\mathrm{RC} 13-251$ & $42^{\circ} 31^{\prime} \mathrm{S}$ & $11^{\circ} 40^{\prime} \mathrm{E}$ & 4341 & 1083 & & (8) \\
\hline $\mathrm{RC} 13-252$ & $45^{\circ} 05^{\prime} \mathrm{S}$ & $09^{\circ} 09^{\prime} \mathrm{E}$ & 4523 & 1233 & & (15) \\
\hline RC13-268 & $57^{\circ} 02^{\prime} \mathrm{S}$ & $00^{\circ} 06^{\prime} \mathrm{W}$ & 4005 & 848 & & (15) \\
\hline RC13-270 & $55^{\circ} 29^{\prime} \mathrm{S}$ & $04^{\circ} 38^{\prime} \mathrm{E}$ & 3160 & 2205 & & (8) \\
\hline RC13-271 & $51^{\circ} 53^{\prime} \mathrm{S}$ & $04^{\circ} 31^{\prime} \mathrm{E}$ & 3634 & 2420 & & (8) \\
\hline RC13-272 & $55^{\circ} 05^{\prime} \mathrm{S}$ & $08^{\circ} 00^{\prime} \mathrm{E}$ & 2538 & 1105 & & (8) \\
\hline RC13-274 & $58^{\circ} 09^{\prime} \mathrm{S}$ & $12^{\circ} 26^{\prime} \mathrm{E}$ & 3372 & 411 & & (8) \\
\hline RC13-277 & $44^{\circ} 34^{\prime} \mathrm{S}$ & $15^{\circ} 46^{\prime} \mathrm{E}$ & 4877 & 1756 & & (15) \\
\hline RC13-278 & $42^{\circ} 04^{\prime} \mathrm{S}$ & $16^{\circ} 44^{\prime} \mathrm{E}$ & 4790 & 1325 & & (15) \\
\hline RC15-96 & $42^{\circ} 53^{\prime} \mathrm{S}$ & $23^{\circ} 55^{\prime} \mathrm{W}$ & 4426 & 1186 & & (8) \\
\hline RC15-99 & $43^{\circ} 01^{\prime} \mathrm{S}$ & $31^{\circ} 10^{\prime} \mathrm{W}$ & 4744 & 1195 & & (8) \\
\hline V9-2 & $01^{\circ} 46^{\prime} \mathrm{S}$ & $35^{\circ} 39^{\prime} \mathrm{W}$ & 3115 & 360 & & (1) \\
\hline V12-18 & $28^{\circ} 42^{\prime} \mathrm{S}$ & $34^{\circ} 30^{\prime} \mathrm{W}$ & 4021 & 1078 & & (1) \\
\hline V12-48 & $46^{\circ} 47^{\prime} \mathrm{S}$ & $58^{\circ} 12^{\prime} \mathrm{W}$ & 2763 & 665 & & (8) \\
\hline V15-137 & $50^{\circ} 23^{\prime} \mathrm{S}$ & $47^{\circ} 24^{\prime} \mathrm{S}$ & 2681 & 735 & & (1) \\
\hline V15-164 & $09^{\circ} 45^{\prime} \mathrm{S}$ & $34^{\circ} 24^{\prime} \mathrm{W}$ & 3588 & 700 & & (1) \\
\hline V16-35 & $17^{\circ} 40^{\prime} \mathrm{S}$ & $15^{\circ} 46^{\prime} \mathrm{W}$ & 3891 & 980 & & $(1,19,20)$ \\
\hline V16-37 & $21^{\circ} 20^{\prime} \mathrm{S}$ & $08^{\circ} 57^{\prime} \mathrm{W}$ & 3908 & 517 & & (1) \\
\hline V16-38 & $22^{\circ} 59^{\prime} \mathrm{S}$ & $06^{\circ} 06^{\prime} \mathrm{W}$ & 4925 & 300 & & $(1,19,20)$ \\
\hline V16-40 & $26^{\circ} 16^{\prime} \mathrm{S}$ & $03^{\circ} 01^{\prime} \mathrm{W}$ & 4740 & 590 & & $(1,19,20)$ \\
\hline V16-187 & $31^{\circ} 28^{\prime} \mathrm{S}$ & $40^{\circ} 05^{\prime} \mathrm{W}$ & 3643 & 735 & & $(1,19,20)$ \\
\hline V16-197 & $15^{\circ} 56^{\prime} \mathrm{S}$ & $35^{\circ} 17^{\prime} \mathrm{W}$ & 4078 & 950 & & (1) \\
\hline V17-124 & $48^{\circ} 34^{\prime} \mathrm{S}$ & $36^{\circ} 04^{\prime} \mathrm{W}$ & 5176 & 291 & & (1) \\
\hline V17-125 & $50^{\circ} 15^{\prime} \mathrm{S}$ & $35^{\circ} 53^{\prime} \mathrm{W}$ & 4689 & 735 & & (1) \\
\hline V18-38 & $36^{\circ} 35^{\prime} \mathrm{S}$ & $50^{\circ} 42^{\prime} \mathrm{W}$ & 4319 & 980 & & (1) \\
\hline V18-113 & $51^{\circ} 00^{\prime} \mathrm{S}$ & $49^{\circ} 08^{\prime} \mathrm{W}$ & 2747 & 34 & & (1) \\
\hline V18-122 & $47^{\circ} 09^{\prime} \mathrm{S}$ & $55^{\circ} 29^{\prime} \mathrm{W}$ & 5576 & 1138 & & (8) \\
\hline V18-137 & $45^{\circ} 36^{\prime} \mathrm{S}$ & $54^{\circ} 36^{\prime} \mathrm{W}$ & 5751 & 954 & & (8) \\
\hline V19-300 & $06^{\circ} 53^{\prime} \mathrm{N}$ & $19^{\circ} 28^{\prime} \mathrm{W}$ & 4263 & 970 & & (1) \\
\hline V19-302 & $10^{\circ} 15^{\prime} \mathrm{N}$ & $25^{\circ} 22^{\prime} \mathrm{W}$ & 5583 & 1037 & & (1) \\
\hline V20-207 & $22^{\circ} 06^{\prime} \mathrm{S}$ & $00^{\circ} 19^{\prime} \mathrm{E}$ & 5349 & 960 & & $(1,19,20)$ \\
\hline V22-38 & $09^{\circ} 33^{\prime} \mathrm{S}$ & $34^{\circ} 15^{\prime} \mathrm{W}$ & 3797 & 1156 & & (1) \\
\hline V22-53 & $28^{\circ} 32^{\prime} \mathrm{S}$ & $29^{\circ} 00^{\prime} \mathrm{W}$ & 3607 & 394 & & (1) \\
\hline V $22-60$ & $28^{\circ} 42^{\prime} \mathrm{S}$ & $29^{\circ} 10^{\prime} \mathrm{W}$ & 3469 & 446 & & (1) \\
\hline V22-61 & $28^{\circ} 41^{\prime} \mathrm{S}$ & $29^{\circ} 08^{\prime} \mathrm{W}$ & 3493 & 365 & & (1) \\
\hline V22-62 & $29^{\circ} 11^{\prime} \mathrm{S}$ & $29^{\circ} 16^{\prime} \mathrm{W}$ & 3043 & 668 & & (1) \\
\hline V22-69 & $28^{\circ} 47^{\prime} \mathrm{S}$ & $32^{\circ} 38^{\prime} \mathrm{W}$ & 2801 & 996 & & (1) \\
\hline V22-72 & $29^{\circ} 18^{\prime} \mathrm{S}$ & $34^{\circ} 42^{\prime} \mathrm{W}$ & 3120 & 875 & & (1) \\
\hline V22-85 & $39^{\circ} 45^{\prime} \mathrm{S}$ & $49^{\circ} 40^{\prime} \mathrm{W}$ & 5411 & 40 & & (1) \\
\hline V 22-87 & $43^{\circ} 30^{\prime} \mathrm{S}$ & $42^{\circ} 45^{\prime} \mathrm{W}$ & 5169 & 1377 & & (8) \\
\hline V22-88 & $45^{\circ} 04^{\prime} \mathrm{S}$ & $40^{\circ} 20^{\prime} \mathrm{W}$ & 4980 & 1637 & & (1) \\
\hline V22-97 & $48^{\circ} 49^{\prime} \mathrm{S}$ & $37^{\circ} 41^{\prime} \mathrm{W}$ & 5401 & 390 & & (4) \\
\hline V22-98 & $47^{\circ} 56^{\prime} \mathrm{S}$ & $35^{\circ} 56^{\prime} \mathrm{W}$ & 5630 & 860 & & (4) \\
\hline V22-144 & $32^{\circ} 46^{\prime} \mathrm{S}$ & $01^{\circ} 39^{\prime} \mathrm{E}$ & 1357 & 344 & & (1) \\
\hline V22-152 & $31^{\circ} 37^{\prime} \mathrm{S}$ & $00^{\circ} 58^{\prime} \mathrm{E}$ & 4319 & 518 & & (1) \\
\hline V22-154 & $31^{\circ} 17^{\prime} \mathrm{S}$ & $02^{\circ} 32^{\prime} \mathrm{E}$ & 1796 & 490 & & (1) \\
\hline V22-158 & $28^{\circ} 52^{\prime} \mathrm{S}$ & $01^{\circ} 55^{\prime} \mathrm{E}$ & 3499 & 425 & & (1) \\
\hline V22-160 & $28^{\circ} 56^{\prime} \mathrm{S}$ & $02^{\circ} 13^{\prime} \mathrm{E}$ & 3147 & 594 & & (1) \\
\hline V22-163 & $26^{\circ} 22^{\prime} \mathrm{S}$ & $00^{\circ} 56^{\prime} \mathrm{E}$ & 4442 & 1080 & & (1) \\
\hline V22-167 & $18^{\circ} 43^{\prime} \mathrm{S}$ & $03^{\circ} 54^{\prime} \mathrm{W}$ & 6020 & 1628 & & (1) \\
\hline V22-170 & $14^{\circ} 38^{\prime} \mathrm{S}$ & $07^{\circ} 34^{\prime} \mathrm{W}$ & 4131 & 1698 & & (1) \\
\hline V22-171 & $13^{\circ} 06^{\prime} \mathrm{S}$ & $09^{\circ} 20^{\prime} \mathrm{W}$ & 4155 & 1677 & & (1) \\
\hline V22-184 & $00^{\circ} 21^{\prime} \mathrm{N}$ & $17^{\circ} 31^{\prime} \mathrm{W}$ & 1712 & 80 & & (1) \\
\hline V22-185 & $02^{\circ} 34^{\prime} \mathrm{N}$ & $19^{\circ} 14^{\prime} \mathrm{W}$ & 4587 & 964 & & (1) \\
\hline V22-189 & $04^{\circ} 56^{\prime} \mathrm{N}$ & $21^{\circ} 07^{\prime} \mathrm{W}$ & 2525 & 961 & & (1) \\
\hline V24-236 & $32^{\circ} 42^{\prime} \mathrm{S}$ & $24^{\circ} 05^{\prime} \mathrm{W}$ & 4089 & 630 & & (1) \\
\hline V24-238 & $31^{\circ} 47^{\prime} \mathrm{S}$ & $29^{\circ} 00^{\prime} \mathrm{W}$ & 3585 & 573 & & (1) \\
\hline V24-240 & $31^{\circ} 44^{\prime} \mathrm{S}$ & $28^{\circ} 12^{\prime} \mathrm{W}$ & 4327 & 949 & & (1) \\
\hline V25-46 & $09^{\circ} 19^{\prime} \mathrm{N}$ & $42^{\circ} 30^{\prime} \mathrm{W}$ & 4310 & 954 & & (1) \\
\hline V25-59 & $01^{\circ} 22^{\prime} \mathrm{N}$ & $33^{\circ} 29^{\prime} \mathrm{W}$ & 3824 & 470 & & (14) \\
\hline V25-73 & $08^{\circ} 39^{\prime} \mathrm{N}$ & $53^{\circ} 09^{\prime} \mathrm{W}$ & 4133 & 533 & & (1) \\
\hline V26-60 & $28^{\circ} 33^{\prime} \mathrm{S}$ & $30^{\circ} 33^{\prime} \mathrm{W}$ & 2593 & 1005 & & (1) \\
\hline V26-68 & $30^{\circ} 21^{\prime} \mathrm{S}$ & $15^{\circ} 48^{\prime} \mathrm{W}$ & 3223 & 442 & & (1) \\
\hline V26-74 & $28^{\circ} 36^{\prime} \mathrm{S}$ & $20^{\circ} 41^{\prime} \mathrm{W}$ & 4513 & 467 & & (1) \\
\hline
\end{tabular}


TABLE 1 - Continued

\begin{tabular}{lllcccl}
\hline $\begin{array}{c}\text { Core/Dredge } \\
\text { Number }\end{array}$ & Latitude & Longitude & $\begin{array}{c}\text { Water } \\
\text { Depth } \\
\text { corrected), } \\
\text { (in m) }\end{array}$ & $\begin{array}{c}\text { Sample } \\
\text { Depth } \\
\text { in Core } \\
\text { (cm) }\end{array}$ & Remarks & Reference ${ }^{\mathrm{a}}$ \\
\hline V26-77 & $28^{\circ} 19^{\prime} \mathrm{S}$ & $20^{\circ} 54^{\prime} \mathrm{W}$ & 4308 & 517 & $(1)$ \\
V26-78 & $27^{\circ} 34^{\prime} \mathrm{S}$ & $22^{\circ} 08^{\prime} \mathrm{W}$ & 4336 & 380 & $(1)$ \\
V26-84 & $30^{\circ} 12^{\prime} \mathrm{S}$ & $35^{\circ} 01^{\prime} \mathrm{W}$ & 1897 & 959 & $(1)$ \\
V29-121 & $29^{\circ} 43^{\prime} \mathrm{S}$ & $03^{\circ} 07^{\prime} \mathrm{E}$ & 2873 & 392 & $(4)$ \\
V31-6 & $28^{\circ} 09^{\prime} \mathrm{S}$ & $31^{\circ} 41^{\prime} \mathrm{W}$ & 4790 & 472 & $(4)$ \\
V31-95 & $27^{\circ} 38^{\prime} \mathrm{S}$ & $44^{\circ} 28^{\prime} \mathrm{W}$ & 2725 & 663 & $(4)$ \\
V31-96 & $28^{\circ} 08^{\prime} \mathrm{S}$ & $42^{\circ} 35^{\prime} \mathrm{W}$ & 2886 & 910 & $(4)$ \\
V31-97 & $27^{\circ} 49^{\prime} \mathrm{S}$ & $42^{\circ} 14^{\prime} \mathrm{W}$ & 2919 & 740 & $(4)$ \\
V31-107 & $24^{\circ} 49^{\prime} \mathrm{S}$ & $42^{\circ} 03^{\prime} \mathrm{W}$ & 2294 & 5 & $(10)$ \\
\hline
\end{tabular}

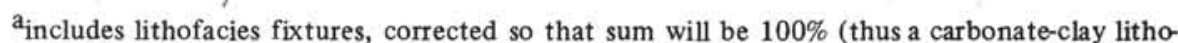
facies would be considered a 50-50 mixture). (1) Saito, 1974 ; (2) L. Burkle, per. com. 1975; (3) H. Thierstein, in press; (4) Unpublished LDGO data; (5) H. Thierstein, per. com. 1976; (6) J. Kosteck, per. com., 1975; (7) Johnson, 1974; (8) J. Hays, per. com. 1976; (9) P. Thompson, per. com. 1975; (10) Damuth, per. com., 1975; (11) D. Johnson, per. com. 1975; (12) Thiede, in press; (13) Percy, per. com., 1975; (14) Damuth, 1973; (15) R. Goll, per. com., 1975; (16) Johnson \& Driscoll, 1975; (17) Lozano-thesis; (18) Hanna, et al., 1976; (19) Ewing, et al, 1976;

(20) Saito, et al., 1966; (21) Ewing \& Lonardi, 1971; and (22) Saito \& Van Donk, 1974.

our knowledge only DSDP Leg 36 (Barker, Dalziel, et al., 1977) and possibly one dredge haul in the Vema Fracture Zone (Honnorez et al., 1975) have recovered material of this age. All palinspastic maps give modern latitudes and longitudes; they should not be interpreted as indicating paleolatitudes, which may have been quite different (see, for example, Phillips and Forsyth, 1972; Ladd, 1974).

\section{Sediment Analysis}

Dates for the majority of piston core and dredge samples have been taken primarily from Saito et al. (1974), from unpublished LDGO data, and from a number of other sources; these are listed in Table 1 (see also Saito and Funnell, 1971). For this study, all of the Cretaceous dates reported by Saito et al. (1974) have been refined to stage designations. Note that sediments described by Saito et al. (1974) as slumped or displaced are included here: our assumption is that these still represent a surface sediment at a particular time regardless of the depositional mechanism, and that this displacement took place within that particular time interval. All dates are based on micropaleontological criteria; none are paleomagnetic or radiometric determinations.

Every dated horizon or sample from piston cores and dredges was sampled. For piston cores the bulk of the dates and samples are from the bases of cores. Examination of smear slides with a petrographic microscope forms the basis of the sediment analysis. Visual estimates were made on the relative percent of major constituents: biosiliceous material; foraminifers (no distinction between benthic and planktonic types); calcareous nannoplankton; indistinguishable calcareous debris including small fragments and micritic material; terrigenous detritus by size group, with additional determinations on the mineralogy of the sand- and silt-sized fraction; volcanic material as glass shards; and other components, such as zeolites, dolomite, glauconite, and opaque material.
Quantitative control on these smear slide estimates was provided by carbonate determinations on all piston core and dredge samples. Visual estimates were rechecked and corrected whenever necessary from this carbonate information. Some samples were analyzed for percent clay-sized material (carbonate-free fraction), as a supplementary check on our visual estimates. In addition, about 150 smear slides were duplicated by both authors to ensure that our visual estimates were consistent and comparable; in most cases, these agreed to within $10 \%$ or less. Similar information for all DSDP sites was taken from data given in the Initial Reports volumes.

Much more data per time interval are available from DSDP data than from core or dredge data; the latter always represent only one sample from any time horizon. To compensate, we averaged all smear-slide and carbonate data from DSDP results per time unit whenever there was no major change in lithologies. If sediment types did change significantly within a particular time interval, as from a limestone to a mudstone, we established two or more data sets as necessary.

\section{Lithofacies Definition}

Four general lithofacies were determined from the smear slide information: calcareous, biosiliceous, fine terrigenous (clay-sized material), and coarse terrigenous (sand- and silt-size material). A fifth type, evaporites, was taken for the Early Cretaceous from Leyden et al. (1976); we did not, however, examine samples of evaporites. A particular lithofacies was indicated whenever $25 \%$ or more of a component was present. For example, if $25 \%$ or more of the sedimentary components were clay-sized terrigenous debris, then the corresponding lithofacies was fine terrigenous. Where two or more lithofacies occur together, a striped pattern was used. We also distinguished a $10 \%-25 \%$ terrigenous sub-facies as an aid in delineating terrigenous influx patterns; this is 
shown as a dotted overprint on Plate 2. Even with a $25 \%$ concentration boundary, very few samples consisted of three types in combination; none were more than three. Because of this, and because of the possible significance of a lithofacies composed of $25 \%$ or more of a particular type of material, we feel that the breakdown and limits used here for defining these lithofacies types was adequately descriptive.

In plotting the distribution of foraminifers and calcareous nannofossils (Plates 4 and 5), the less-than$20 \%$ contour interval has been subdivided into a $10 \%$ to $20 \%$ portion and a less-than-10\% portion. This allows a better definition of trends, especially since these components often occur in low amounts.

Boundaries between lithofacies or other components are shown as solid lines where data permit confident establishment of contacts, or as long dashes where data are insufficient. Blank areas indicate no data.

\section{Assumptions and Restrictions}

Distributions of lithofacies, as well as other components (carbonate, foraminifers, calcareous nannofossils), represent our interpretations of their areal extent. These interpretations are based upon two assumptions: (1) the expected topographic symmetry of the basin, where a medial spreading ridge exists flanked by deeper basins; and (2) the establishment and continuation of trends from older time-slices to successively younger time-slices. Thus, for example, one data point indicating a calcareous lithofacies near the crest of the Mid-Atlantic Ridge would suggest a similar lithofacies in about the same position on the opposite side of the ridge crest where we have no sample. Although locally complex, the isopach map of Ewing et al. (1973) shows a high degree of symmetry with respect to sediment thickness across the axial region of the Mid-Atlantic Ridge, which suggests that some degree of symmetry may be extended also to the sediment lithofacies. Carbonate maps of recent sediments (Figure 3, Biscaye et al., 1976) also reveal this relationship. Clearly, these assumptions must be applied with discretion, especially in basins where relative subsidence rates may be different, and along continental margins where sedimentation processes are much more likely to be controlled by local conditions. Also, it is important to note that the modern MidAtlantic Ridge is markedly asymmetrical between the Walvis Ridge and the Romanche-Chain Fracture Zone area; the median valley and crestal area are offset to the west and the eastern flank is thus considerably wider (Van Andel and Heath, 1970). For carbonate distributions, these assumptions must also be applied with discretion; for example, the modern CCD is considerably lower in the Angola Basin than in either the Brazil or Argentine Basins (Berger and Winterer, 1974), and could very well have been so in the Tertiary.

Few piston cores provide sufficient biostratigraphic data and only DSDP sites adequately indicate hiatuses. The geographic extent of hiatuses in our time intervals are, therefore, indefinite with regard to this summation.

On the lithofacies distribution maps (Plate 2), a mixed assemblage such as a carbonate-biosiliceous assemblage may represent either coexisting sediment types at the end of a particular time-slice, or a vertical stratigraphic change in sediment types during that epoch. Thus, for example, a carbonate lithofacies could have changed to a biosiliceous lithofacies within one epoch; this would be applicable only to DSDP sites. Any sequence reflecting short periodicity processes, such as carbonate dissolution cycles described by Melguen et al. (1975), will not be apparent here. It should be emphasized once again that the data and our discussion represent generalizations of the information available and do not allow a further subdivision by time interval, although we realize that physical processes are not restricted by artificial epoch boundaries nor constant within an epoch.

Most of the data are from piston core and dredge samples. Each such sample, usually from the bottom of a core, represents only one small interval within any time sequence from which we do not have additional information. Little biostratigraphic control is available in the literature on the cores used here, and probably no core completely penetrated any particular epoch. This is a severe restriction, and must be kept in mind. Thus, for most data points we have no vertical stratigraphic control. In contrast to drilling data from DSDP, one piston core or dredge sample must be assumed to be indicative of the entire epoch. It is because of DSDP and the coring during Leg 39 , however, that maps such as these can now be assembled.

Where a coarse terrigenous lithofacies is plotted, it should also be remembered that these are predominantly coarse silts or very fine sands which may constitute as little as $25 \%$ of the total sediment (see Methods). In no case should it be construed that we are indicating a porous sand deposit with an absence of fine-grained matrix.

We have not extended lithofacies distributions by using seismic profiles, nor have we projected this interpretation to sediments in marginal continental basins, although information on these exists in the literature. It would be inconsistent to our scheme simply to apply often-vague sediment descriptions from published accounts to our data from cores and dredges. It would also dilute the interval consistency, which is created here by using descriptions based on direct observation or quantitative information based on DSDP Initial Reports. We acknowledge, however, the importance of sediments in these marginal basins. If these are early features produced during initial periods of ocean basin formation, as suggested by Francheteau and Le Pichon (1972) and many others, then it is clear that much of the early sedimentation history of the South Atlantic is contained in these coastal basins. Data from marginal basins, therefore, will be incorporated in a later version, and will require extensive interpretation.

\section{LITHOFACIES DISTRIBUTION}

\section{Introduction}

Sediment lithofacies maps (Plate 2) essentially portray surface sediment distributions at the 
termination of each epoch. Additional plates present the distribution of various components-percent carbonate (Plate 3) and the two main calcareous components, foraminifers (Plate 4) and calcareous nannofossils (Plate 5).

It would be advantageous to continue comparisons in lithofacies up to modern sea-floor conditions. But complexities connected with relatively short but intense climatic cycles during the Pleistocene, together with corresponding changes of sea level and circulation patterns, have often left an imprint on modern surface sediments that make an extension of our scheme difficult. We have therefore restricted this study to prePleistocene sediments.

\section{Early Cretaceous}

\section{Sediment Lithofacies}

Data are sketchy for this time interval (Albian or older), but the basin is relatively small. Dominant here (Plate 2) are the Aptian evaporite deposits, whose extent and boundaries are taken from Leyden et al. (1976). Their southern boundary was a sill separating the smaller, perhaps shallower, northern basins, containing salts, from the deeper southern (Argentine and Cape) basins. This sill later evolved into the present Rio Grande Rise-Walvis Ridge system. South of the evaporites, the lithofacies are a mixed terrigenouscalcareous type. This may indicate that locally strong currents flowed over portions of the evaporite basin sill; post-Aptian thin laminae of apparently winnowed foraminifer tests, for example, were recovered at Site 356 (this volume). A calcareous lithofacies, probably also a post-evaporite deposit, occurs farther to the southwest. Pastouret and Goslin (1974) report an Albian-Cenomanian chalk, from the northeastern part of the Walvis Ridge $\left(19^{\circ} 33^{\prime} \mathrm{S}, 09^{\circ} 01^{\prime} \mathrm{E} ; 2700 \mathrm{~m}\right)$, that may be partly coincident with this calcareous lithofacies. North of the evaporites, Early Cretaceous argillaceous and calcareous sediments were deposited in the Benue Trough area (Delteil et al., 1974). Paleocurrent determinations in Albian formations in Nigeria, however, do not indicate significant detrital transport to the southwest into the ancestral South Atlantic (Adeleye, 1975).

Calcareous deposits occur on the Falkland Plateau and will persist here up to the Pliocene. Sliter (1976) estimates that water depths on the plateau during the Early Cretaceous were 100 to 400 meters.

Terrigenous components are not surprising in this early stage of the South Atlantic, which was a relatively narrow and probably shallow, but deepening, basin, where most areas of the sea floor were close to source areas. In view of the Early Cretaceous transgressions (Figure 2) and the extensive subsidence and filling of marginal basins, the presence of coarse terrigenous mixtures in numerous areas of the sea floor seems surprising. These coarse terrigenous components may (Plate 2) represent marine distal extensions of continental marginal basins. Butler (1970), Campos et al. (1974), and Reyment (1973), for example, describe late Jurassic to Neocomian sediments in South Atlantic marginal basins as narrow elongate deposits of proximal continental fluvio-lacustrine material, and the Espirito Santo Basin in northern Argentina was also filled with a thick sequence of clastic material, particularly in Aptian-Albian time (Leyden et al., 1971).

We do not distinguish in this discussion between oxygenated and anoxic depositional environments. Sapropels and black shales, by the lithofacies identification scheme used here, would be a fineterrigenous deposit. Indeed, some of the samples for this time slice, as well as some used on the Late Cretaceous map (post-Albian samples), are sapropels and black shales reflecting bottom-water stagnation during the post-Aptian evaporite stage in the South Atlantic (see Paleocirculation below).

\section{Carbonates}

Carbonate values (Plate 3 ) are similarly sketchy for this time period, but vary between $20 \%$ and $80 \%$. Lower values generally correspond to areas receiving significant amounts of terrigenous material. The one high value on the Falkland Plateau probably indicates local biologic activity. Through comparison with Late Cretaceous conditions, the entire central area of this Early Cretaceous basin may be assumed also to have been carpeted with carbonate-rich sediments; if CCD levels were about 3300 to 3700 meters (Figure 2; van Andel, 1975), then this sea was considerably shallower than its modern counterpart.

\section{Foraminifers and Calcareous Nannofossils}

Little can be said about the distribution of foraminifers and calcareous nannofossils, except that foraminifers occur in low amounts in these Lower Cretaceous sediments (Plates 4 and 5). Calcareous nannofossils apparently form the bulk of the calcareous portion of the sediment.

\section{Late Cretaceous}

\section{Sediment Lithofacies}

Better data are available for interpreting Late Cretaceous sediment distributions (Plate 2). Included here are all samples of Cenomanian through Maestrichtian age, although most are Maestrichtian (Table 1).

A pronounced influx of terrigenous detritus from South America, indicated by the calcareous-clay sediment distribution, is evident on the Falkland and São Paulo Plateaus (as noted by Ioannides and Colin, this volume) and in the Argentine Basin, as well as in western equatorial regions parts of the Atlantic. According to many authors (Short and Stauble, 1967; Zambrano and Urien, 1970; Ponte and Asmus, 1976), such an influx occurred from the Cenomanian through the Coniacian. It was ended by the Maestrichtian transgression (Figure 2) when this detritus was trapped within, and filled coastal marginal basins up to $4 \mathrm{~km}$ of sediment (Butler, 1970; Leyden et al., 1971). Terrigenous material off southern South America was probably derived from the Andean Cordillera which were uplifted in the Albian-Cenomanian (Dalziel, 1974). 
Dispersal of finer detritus throughout the Argentine Basin may indicate the development of sporadic, tractive bottom currents after the end of restricted circulation in the Campanian. It appears that the Rio Grande Rise was an effective barrier to a deep water connection between the Argentine and Brazil Basins, as has also been proposed by Reyment and Tait (1972) from paleontological criteria. Ostracodes suggest minimum water depths on the Rio Grande Rise at Site 357 of 800 to 1000 meters in the Late Cretaceous (Benson, this volume).

Patterns of $10 \%$ to $25 \%$ terrigenous material (Plate 2) extending northeasterly from the Argentine Basin over the Rio Grande Rise-Mid-Atlantic Ridge area could indicate dispersal of clays by surface currents or winds. Montmorillonite-zeolite-volcanic glass mixtures in sediments here suggest some local derivation from nearby volcanic areas (see Site 357, this volume; Zimmerman, this volume; McCoy et al., this volume). Fine terrigenous mixtures on the São Paulo Plateau, on the other hand, appear partly to represent a Brazilian source (Kumar et al., this volume; Zimmerman, this volume; Krinsley and $\mathrm{McCoy}$, this volume). Uplift of the Sierra do Mar mountains in southeastern Brazil did produce a rapid influx of terrigenous sediment into the São Paulo embayment (Butler, 1970) that may, in part, represent the source for the coarse terrigenous lithofacies here (composed predominantly of coarse siltsized grains of quartz).

Coarse terrigenous lithofacies in the northern portion of the Brazil Basin represents both an influx of continental detritus and subsidence of the basin below carbonate dissolution levels (Bader, Gerard, et al., 1970).

Calcareous lithofacies outline the Walvis Ridge, the Rio Grande Rise, portions of the Mid-Atlantic Ridge and the southern portion of the Brazil Basin. Extension of carbonate-rich sediments to the northeastern part of the Walvis Ridge is based upon the AlbianCenomanian chalk dredged there by the Jean Charcot (Pastouret and Goslin, 1974).

Little information exists for the Angola Basin. During Turonian time, the Benue Trough formed an important connection between the Angola Basin and the Tethys seaway (Reyment and Tait, 1972). Significant sediment transport occurred in this trough according to Adeleye (1975); west of the trough (near the modern Niger Delta), marginal basins were filled with nearly 5 kilometers of sediments by the Santonian (McConnell, 1969). By the Campanian, however, this connection was not as important, and terrigenous influx, both from continental areas and possibly from the Benue Trough, had ceased; sediments in the Angola Basin were predominantly calcareous (Bolli, Ryan, et al., 1975).

Equatorial areas continue to have a mixed calcareous-terrigenous lithofacies, reflecting the close proximity of continents and continental margins to the widening ocean basin. Much of the clay component here may be a result of redepositional processes (Hayes, Pimm, et al., 1972), perhaps related to an invigorated oceanic circulation when the North and South Atlantic oceans joined during the Late Cretaceous.
The Falkland Plateau also received contributions of fine terrigenous material, apparently derived from the uplifted Andean Cordillera (Zambrano and Urien, 1970; Barker, Dalziel, et al., 1977). Coarser terrigenous material on the plateau could represent winnowing of sediments by currents, reflecting changing circulation patterns and subsidence of the Falkland Plateau (Barker, Dalziel, et al., 1977).

\section{Carbonates}

The distribution of high carbonate values (Plate 3) in a wide zone through the center of the sea describes an area remote from the influence of continental debris; it may also portray a broad, low medial-ridge physiography. The contribution of detritus from South America into the Argentine Basin is particularly clear, and its distribution suggests dispersal by a clockwise circulation pattern (Figure 5). As noted previously, depositional conditions below a carbonate dissolution level occur only in the northern Brazil Basin. With CCD levels probably between 3200 and 3600 meters (van Andel, 1975; see also Figure 2), most of the Late Cretaceous sea floor continued to be much shallower than its modern equivalent, but similar to that of the Early Cretaceous.

\section{Foraminifers and Nannofossils}

The first good indication of the areal extent and variation in abundance of foraminifers and calcareous nannofossils in bottom sediments can be seen in the Late Cretaceous (Plates 4 and 5). High concentrations coincide with areas where dilution by continental detritus is minimal, particularly for calcareous nannofossil distributions. In the central portion of the Brazil Basin, and possibly in the Argentine Basin, preservation indicates deposition near or just above a CCD level (see Biostratigraphic Summaries, Sites 355 and 358, this volume).

\section{Paleocene}

\section{Sediment Lithofacies}

Carbonate lithofacies continue to outline the Rio Grande Rise-Walvis Ridge system and central portions of the sea floor (Plate II). Even with continued subsidence in the Paleocene (Thiede, in press), the Rio Grande Rise-Walvis Ridge appears to have remained a major east-west barrier to deep circulation. Water depths on the Rio Grande Rise-São Paulo Plateau may have been as shallow as 800 to 1000 meters (Benson, this volume), well above carbonate dissolution levels (van Andel, 1975; see also Figure 2). Argentine Basin sediments have a terrigenous component mixed with carbonates, but the pronounced influx of continental detritus into the basin has apparently ceased, despite the change of regional paleoslopes in Argentina from the Pacific toward the Atlantic (Zambrano and Urien, 1970), when such an influx might be expected.

Coarser terrigenous material occurs in the southern Brazil Basin just north of the Rio Grande Rise. This is recorded by only one core and could, therefore, represent slump or turbidite deposits. The distribution of samples containing $10 \%$ to $25 \%$ terrigenous material 


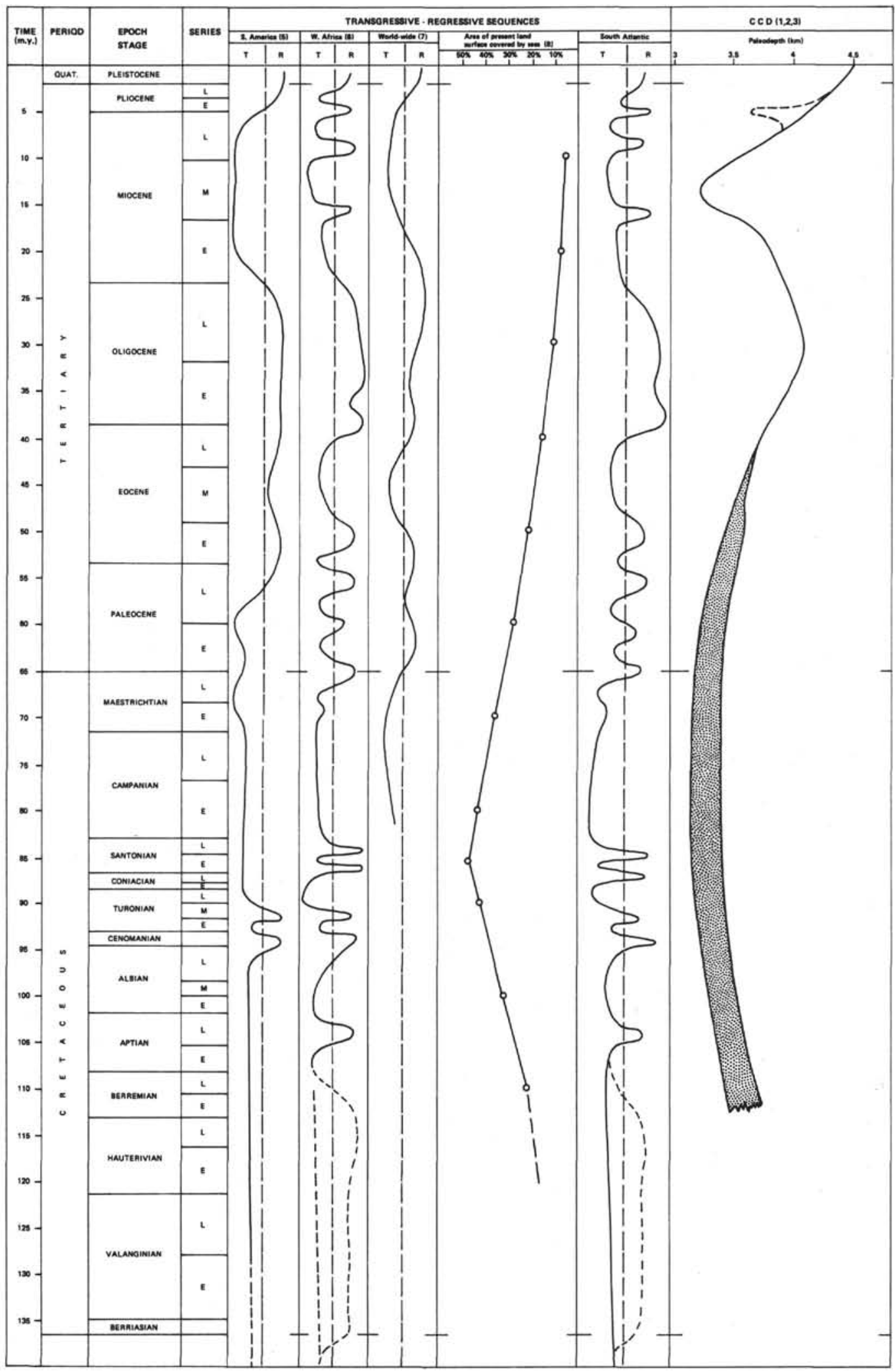

Figure 2. Graph illustrating the relationships between lithofacies changes and variations in $C C D$ levels, hiatuses, transgressive-regressive sequences, and oxygen isotope measurements in the South Atlantic Ocean. Time-scale and stages from Thierstein (in press) and Berggren (1972); Cretaceous series divisions made relative to stages of van Hinte (1976). Other references as follows: CCD (1) Berger and von Rad (1972), (2) Van Andel (1975), and (3) Ryan et al. (1974). Hiatuses: (4) Boersma (this volume). Transgressive-regressive sequences: South America: (5) Harrington (1956a, b), Reyment (1969), Zambrano and Urien (1970), Reyment and 
HISTORY OF SEDIMENT LITHOFACIES

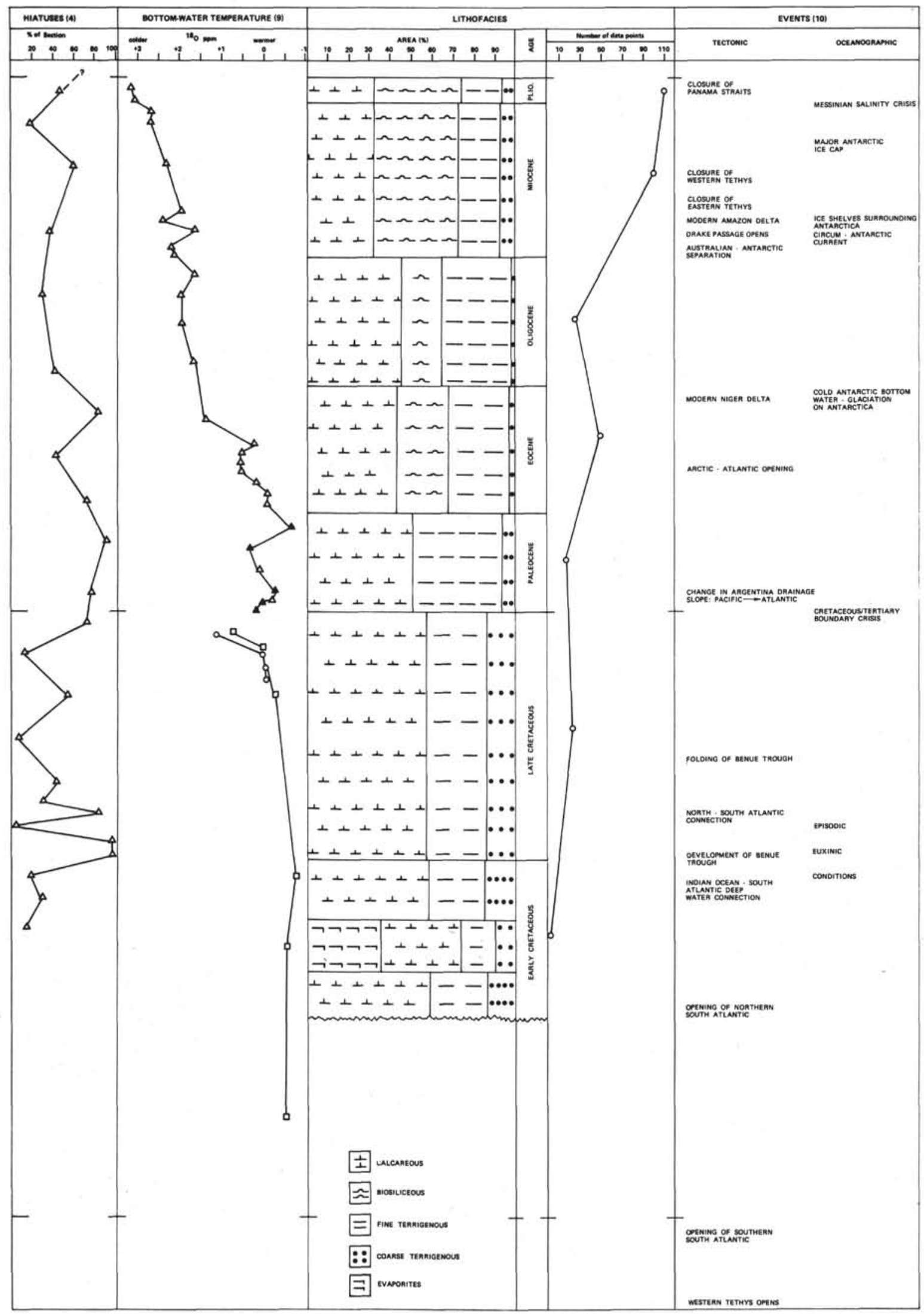

Figure 2. (Continued). Tait (1972), Urien and Zambrano (1974), Asmus and Ponte (1974), and Campos et al. (1974). West Africa: (6) Short and Stauble (1967), Reyment (1969), Reyment and Tait (1972), Dingle (1971, 1973b, c), Dillon and Sougy (1974), Delteil, et al. (1974), and R. Hedberg, personal communication. World-wide: (7) Fleming and Roberts (1973). Area of present land surface covered by seas: (8) Hays and Pitman (1973). Bottom-water temperature: (9) Boersma and Shackleton (this volume [solid 
triangles, Site 356; open triangles, Site 357]), Saito and van Donk (1974 [circles]), and Douglas and Savin (1975 [squares]). Events: (10) Berggren and Hollister (1974), Kennett, Houty, et al. (1975, Leg 29), Shackleton and Kennett (1975), Premoli-Silva and Boersma (this volume), Burke et al. (1971), Short and Stauble (1967), Damuth and Kumar (1975), Reyment and Tait (1972), Reyment (1969) and Ladd (1974).

(dotted pattern, Plate 2) indicates an influx of silts and possibly clays throughout the southern portion of the Brazil Basin. It appears doubtful that surface currents would have continued to transport clays to the north over the Rio Grande Rise, as they did in the Late Cretaceous, since the supply of terrigenous material from South America into the Argentine Basin seems to have diminished. Both the coarser detritus and the clays more likely represent both a dissolution effect and local derivation from the São Paulo Plateau and the continental margin just north of it, probably in connection with Paleocene transgression-regression cycles. Certainly subsidence of the central Brazil Basin below dissolution levels accounts for the clay lithofacies there (Site 355, this volume). Although volcanic islands may have capped the Rio Grande Rise during the Paleocene (Site 357, this volume), volcanic components are absent in these southern Brazil Basin sediments. Along the northeastern boundary of the basin, carbonates on the Mid-Atlantic Ridge (not shown on Plate 2) are inferred from Cifelli et al. (1968), who report "chalky friable oozes" here.

During the Paleocene, the first appearance of a biosiliceous lithofacies occurs in two areas: on the Falkland Plateau, as a mixed biosiliceous-clay sediment, and on the Rio Grande Rise, as a mixed biosiliceous-calcareous sediment. Both could represent local productivity effects. There is, however, evidence for a slight cooling during the late Paleocene (Boersma and Shackleton, this volume; see also Figure 2). The biosiliceous component on the Falkland Plateau is of late Paleocene age, according to Barker, Dalziel, et al. (1977), and may be the first indication of the effects of cooler water masses possibly perhaps flowing through a gap in the plateau. Clays here indicate continued easterly transport of terrigenous sediment from South America, resulting from erosion of the southern Andean Cordillera.

Terrigenous sediment south of the Walvis Ridge represents the westernmost extent of sediment filling the Cape Basin from the ancestral Orange River. Dingle and Scrutton (1974) and others have noted such an influx of African-derived detritus during the Cretaceous, and this early Paleocene marine deposit could represent the final stages of filling. Pastouret and Goslin (1974) describe subsidence of the eastern portion of the Walvis Ridge after middle Cretaceous time, but preliminary results from Leg 40 drilling sites indicate a calcareous lithofacies here from the Paleocene to the Oligocene (Melguen, et al., 1975; Bolli, Ryan, et al., 1975); thus, the absence of carbonates is not attributable to dissolution effects.

Mixed calcareous and fine-terrigenous sediment persist in equatorial areas. Sedimentation patterns in this area have not changed greatly since the Early Cretaceous.

\section{Carbonates}

High carbonate values in the Paleocene are restricted to a narrow east-west zone over the Rio Grande RiseWalvis Ridge area, in contrast to distributions during the Late Cretaceous. A sharp gradient in carbonate values north of the rise suggests a clearly developed CCD level, probably close to CCD levels of the Late Cretaceous (3200-3600 m; van Andel, 1975; Figure 2). If these carbonate distribution patterns reflect preservation of calcareous material in sediments above this level, it could indicate that the Paleocene MidAtlantic Ridge may have been a topographically high area only immediately north and south of its juncture with the Rio Grande Rise and the Walvis Ridge. Lower carbonate values toward the southerly portion of the Argentine Basin (data here based also upon unpublished information, courtesy of P. Ciesielski) and in the Brazil Basin suggest subsidence below the CCD.

\section{Foraminifers and Calcareous Nannofossils}

Generally, the distributions of both foraminifers and calcareous nannofossils in Paleocene sediments (Plates 3 and 4) closely correspond to overall carbonate distributions. The pattern of high values for both points to the continued presence of the Rio Grande RiseWalvis Ridge area as a barrier to deep circulation connection between the northern and southern portions of this sea.

\section{Eocene}

\section{Sediment Lithofacies}

By the end of the Eocene, the combined effects of continued subsidence, climatic cooling, and major changes in circulation patterns have had a profound effect on sediment lithofacies distributions. Calcareous sediment continued to occupy the physiographically continuous Rio Grande Rise-Walvis Ridge barrier and higher portions of the Mid-Atlantic Ridge.

The Argentine Basin now contained a mixed calcareous-clay-biosiliceous sediment, and the Falkland Plateau was coated with predominantly biosiliceous sediment-the first widespread occurrences of biosiliceous material in the South Atlantic. Small patches of calcareous material remained on the plateau, along portions of the southern South American margin, and in one area at the tip of the continent. A renewed influx of terrigenous sediment into the Argentine Basin is evident, and may be related to short-period transgression-regression cycles (Figure 2). This is most pronounced off the area of the modern Rio Plata estuary, but is also evident as far north as the São Paulo Plateau and as far south as the Falkland Plateau. On the plateau, Barker, Dalziel, et al. (1977) attribute these clays to continued erosion of the southern Andean Cordillera. 
Clearly a colder bottom water, which we would identify as a pre-Antarctic Bottom Water (pAABW; see Paleocirculation below), had intruded into and spread throughout the Argentine Basin by the end of the Eocene. This intrusion was in response to the marked climatic cooling and initiation of glaciation of Antarctica in the late Eocene (Boersma and Shackleton, this volume; Savin et al., 1975; Douglas and Savin, 1975; Geitzenauer et al., 1968; and many others). Early to middle Eocene near-surface waters were considerably warmer $\left(20^{\circ} \mathrm{C}\right)$ than in the Paleocene, whereas late Eocene temperatures had decreased to about $9^{\circ} \mathrm{C}$ (Shackleton and Boersma, this volume). Productivity of biosiliceous organic material increased as a result of these cooler southern waters (Hays, 1965), corresponding to Ramsay's (1973) southern silica belt of deposition of organic-siliceous material. The presence of carbonates in the Argentine Basin reflects a facies change from carbonate-clay to biosiliceous-clay during the Eocene (they are not co-existing sediment types). This facies change also represents middle Eocene subsidence below the CCD, as well as the late Eocene introduction of cool pAABW.

Biosiliceous material is also present with calcareous sediment on the São Paulo Plateau. It is not clear whether productivity of biosiliceous material here was related to possible upwelling or to vulcanism; Eocene vulcanism was apparently extensive along this entire east-west ridge (see Site 357, this volume; Zimmerman, this volume). It is clear, however, from the geographic distribution of lithofacies types, that the São Paulo Plateau-Rio Grande Rise-Walvis Ridge system still formed a transverse barrier to deep circulation in the South Atlantic at the close of the Eocene.

A marked change in sediments and oceanographic conditions had also occurred in the northern portion of the Eocene South Atlantic Ocean. What earlier was predominantly a calcareous-clay sediment had been partially replaced by biosiliceous and calcareous sediments. Additional drilling on the Sierra Leone Rise (Lancelot, Siebold, et al., 1975) has yielded early and middle Eocene sediments containing significant quantities of biosiliceous material. The biosiliceous material could reflect an equatorial zone of upwelling, or the continuous belt of middle Eocene biosiliceous sediment inferred by Ramsey $(1973,1976)$ and related by him to "an influx of nutrient-rich Pacific equatorial water through an open Isthmus of Panama." Our data, however, suggest a more limited distribution of biosiliceous deposits. Carbonate sediments still mantle the equatorial Mid-Atlantic Ridge northeast of the Brazil Basin where Cifelli et al. (1968) describe a dredge haul with "chalky ooze" (not shown on Plate 2). This calcareous material could be related to mid-ocean equatorial productivity belts in an area of minimal contributions of non-carbonate detritus on a ridge system now more distal from the continents.

Unfortunately, data remain poor for the Angola Basin. A significant terrigenous influx might be expected in conjunction with the transgressionregression cycles (Figure 2) and the development of the modern Niger Delta (Stonely, 1966; Short and Stauble, 1968).

\section{Carbonates}

Low carbonate values throughout the southern portion of the Argentine Basin indicate its continued subsidence below carbonate dissolution levels and the intrusion of cool pAABW. Early Eocene calcareous foraminifer assemblages at Site 358 suggest a depth close to a fluctuating CCD level (see Boersma, this volume); according to van Andel (1975), this would have been about 3600 to 3900 meters. The influx of terrigenous debris from southern South America resulted in low carbonate contents in sediments along the basin margin. A small area of high carbonate values, however, persisted along the northern edge of the Falkland Plateau.

High carbonate values are restricted to topographically positive areas, such as along the Walvis Ridge and the Rio Grande Rise. Subsidence formed a saddle (Hunter Channel) between the Rio Grande Rise and the Mid-Atlantic Ridge, which is evident from lower carbonate values in this area, and the Rio Grande Rise has increasingly become an isolated region of sediments with higher carbonate contents.

Throughout the Brazil Basin, deposition below CCD levels resulted in low carbonate values. In equatorial areas, increased carbonate content in sediments are related to preservation on topographically high areas such as the Mid-Atlantic Ridge (in conjunction with lowered CCD levels), to an equatorial productivity belt, and to absence of a significant contribution of terrigenous detritus.

\section{Foraminifers and Calcareous Nannofossils}

As in the Paleocene, the distributions of foraminifers and calcareous nannofossils in surface sediments at the close of the Eocene generally follow carbonate distributions. This is particularly the case for calcareous nannofossils. Gradients in abundances for both of these biogenic components define CCD levels along the slope between the Rio Grande Rise and the Brazil Basin, but are not as well defined south of the rise. On both the Rio Grande Rise and the Walvis Ridge the change in the pattern of high abundances, relative to the Paleocene pattern, was probably in response to changing physiography; note in particular the change in high values for calcareous nannofossils.

\section{Oligocene}

\section{Sediment Lithofacies}

Coverage is adequate in the Oligocene to suggest changes in sediment distributions and corresponding modifications in sedimentary processes, circulation patterns, and alterations in sea-floor physiography. Most outstanding is the complete disappearance of a calcareous component in Argentine Basin sediments because of subsidence of the basin floor below a welldefined CCD level and the complete intrusion of the deep, cold pAABW as far north as the Rio Grande Rise and São Paulo Plateau area (see also Benson, this volume). This cold bottom water $\left(4-6^{\circ} \mathrm{C}\right.$, Boersma and Shackleton, this volume) reflects the development of a continental ice sheet and a cold water mass surrounding Antarctica (Douglas and Savin, 1975; Shackleton and 
Kennett, 1975; Savin et al., 1975). The complete separation of Australia and South America from Antarctica (the latter separation forming the Drake Passage [La Brecque, in preparation]), allowed development of a Circum-Antarctic Current during the late Oligocene and establishment of a strong thermohaline circulation pattern.

Despite a major Oligocene regression and the change from a generally warm Eocene climate to a cooler Oligocene climate (Figure 2), there is no evidence of an increase in terrigenous influx from land. There is also a lack of terrestrially-derived palynomorphs in the central-northern area of the Argentine Basin (Site 358; see Ioannides and Colin, this volume). Carbonate sediments occur only locally on the Falkland Plateau. Some clay in the southeastern portion of the Argentine Basin may represent deposition from currents sweeping over the Falkland Plateau, analogous to modern conditions.

A calcareous lithofacies outlines the Mid-Atlantic Ridge and the Walvis Ridge and extends southerly along portions of the South African continental margin and into the Cape Basin (Melguen et al., 1975), suggesting decreased terrigenous detritus from the African continent.

Subsidence between the Rio Grande Rise and the Mid-Atlantic Ridge has resulted in a channel defined with respect to the 2000 fathom (3660 meters) contour line. This channel, the Hunter Channel (Burckle and Biscaye, 1971), contains a carbonate-clay lithofacies, suggesting that subsidence has progressed to depths where a southerly mid- to deep-water mass (Plate 6) could transport clays into the channel from the Brazil Basin. A deep-water exchange between the northern and southern South Atlantic Ocean has thus commenced.

West of the Rio Grande Rise, the Rio Grande Gap is also indicated by the break in the 2000 fathom (3660 meters) isobath, but our data are insufficient to resolve its effect upon north-south water exchange. A terrigenous component in Upper Cretaceous sediments was noted here and a terrigenous component is again present in the Oligocene. Limited water exchange might be suggested, but if so, then it has had relatively little effect upon the distribution of lithofacies in the Brazil and Argentine Basins. Thẽ broad extent of clay lithofacies in the Brazil Basin, particularly in the south, reflects continued subsidence of the basin below CCD levels during the late Oligocene.

Carbonate lithofacies dominate the equatorial portion of the sea. The small area of clay off northern Brazil could indicate an ancestral Amazon drainage network in the late Oligocene. Biosiliceous material probably represents an equatorial productivity phenomenon, but could also represent, in part, productivity related to river water drainage analogous to modern conditions (although at present this effect is considerably north of the river mouth, according to Ryther et al., 1967, and Milliman et al., 1975a, b).

\section{Carbonates}

By the close of the Oligocene, the zone of high carbonate content in sediments (greater than $60 \%$ ) had expanded significantly in the central South Atlantic. North of the Walvis Ridge, it appears to outline a median ridge area. The east-west zone of carbonate contents greater than $80 \%$ along the Walvis Ridge had narrowed considerably, but extended southerly along the southern African continental margin. The Rio Grande Rise remained an isolated physiographic feature with similarly high carbonate contents in surface sediments. At the northern part of the MidAtlantic Ridge, a small area of greater than $80 \%$ carbonate content may have resulted from an uplifted block adjacent to a fracture zone, much as Bonatti and Honnorez (1971) have proposed for the Vema and Romanche fracture zones.

Carbonates occur in small amounts in surface sediments throughout the Argentine Basin due to further subsidence below carbonate dissolution levels particularly to the north near the Rio Grande Rise, and continued intrusion of pAABW into the basin. Continued subsidence of the southern portion of the Brazil Basin has also resulted in low carbonate concentrations in sediments. High gradients in carbonate values along basinal slopes in both basins imply well-defined CCD levels.

In equatorial regions, carbonate values in excess of $80 \%$ may indicate increased topographic development of the Mid-Atlantic Ridge, but are also undoubtedly related to other factors such as productivity effects, a drop in CCD levels (Figure 2), and the increasingly isolated position of the sea floor here from terrigenous material.

Marginal portions of the Cape Basin still remained above carbonate dissolution levels; the Angola Basin, on the other hand, had now subsided below this level (Melguen et al., 1975).

\section{Foraminifers and Calcareous Nannofossils}

Distributions of these biogenic calcareous components also define a narrow and elongate area extending northerly from the juncture of the MidAtlantic Ridge and the Walvis Ridge-again suggesting that an elevated topography along the Mid-Atlantic Ridge had developed by the close of the Oliogcene, or that a late Oligocene warming trend (Figure 2) had resulted in an expansion of calcareous nannofossil distributions, as noted by Haq and Lohmann (1975). Calcareous nannofossil abundances contribute to high carbonate values in sediments on the Falkland Plateau; foraminifers here are only a minor component, because of continued climatic deterioration (Barker and Dalziel, 1977). Gradients of abundances in both foraminifers and calcareous nannofossils indicate similar CCD levels in both the Argentine and Brazil Basins, as might be expected with the newly established mid-water exchange through the Hunter Channel.

\section{Miocene}

\section{Sediment Lithofacies}

Calcareous lithofacies occupy a narrow zone along central portions of the sea from equatorial areas to the Walvis Ridge, apparently defining first-order topographic features of the Miocene sea. Data are now 
adequate to identify this zone as a continuous feature where carbonates were deposited above their dissolution levels despite the pronounced rise in CCD levels (Figure 2). Data remain somewhat poor along portions of the Mid-Atlantic Ridge and in the Angola Basin. Along the flank of the ridge in the northeastern Brazil Basin area, the clay-carbonate boundary has been determined from sediment descriptions given by Cifelli (1970; positions not shown on Plates 1 and 2). Carbonates generally continue as a dominant sediment type from the Walvis Ridge onto and southerly along the South African continental margin. They are supplanted near the tip of South Africa by a coarse terrigenous sediment that becomes a mixed terrigenous lithofacies in the deeper waters of the southern Cape Basin. According to Siesser (1972) and Dingle (1971), the shelf and slope areas along most of southern Africa were covered in the Miocene by a calcareous lithofacies; thus terrigenous material noted here on continental slopes probably represents mass wasting processes and deposition below CCD levels. The location of the coarse terrigenous lithofacies corresponds to an area of massive slides just south of the zone of thickest Neogene sediments described by Emery et al. (1975a) from seismic profiles. The southern boundary of terrigenous material appears to have been the Agulhas Fracture Zone.

At high latitudes, the entire sea floor is extensively carpeted with a biosiliceous lithofacies. By the close of the Miocene, glaciation and extensive ice shelves were well-established on Antarctica (Denton et al., 1971; Frakes and Kemp, 1973; Kennett et al., 1972), and this, coupled with a strong and newly-formed Antarctic Circum-polar Current through the Drake Passage, led to development of a true Antarctic Bottom Water (AABW) flowing northerly into both the Cape and Argentine Basins (see Paleocirculation, below). In the Argentine Basin, the clay-biosiliceous sediments occupy about the same area of basin floor as was suggested for the Oligocene. Apparently this pattern defines the off-shore limit for transportation of South American terrigenous material in response to the bottom water gyre of the Argentine Basin. Clay mineral suites in modern sediments of the basin do not suggest derivation from the Southern Ocean or significant northward transport of terrigenous material by the AABW (Zimmerman, this volume).

There is a distinct zone of mixing between biosiliceous sediment and calcareous sediment in the Cape Basin and on the Mid-Atlantic Ridge. Carbonates persist locally at high latitudes. In the vicinity of Bouvet Island, they are mixed with biosiliceous material. Additional occurrences can also be seen on the Falkland Plateau. Apparently they define topographically high areas where carbonate dissolution effects were minimal, rather than areas where dilution by non-calcareous material was significant.

The entire continental margin off Argentina is marked by coarse and fine terrigenous sediments. Interestingly, the pattern of these two components here is similar to that of sediment accumulations noted by Ewing and Lonardi (1971, p. 136) where thicknesses greater than 2000 meters seem to correspond to the distribution of a coarse terrigenous lithofacies, and sediment thicknesses of less than 1000 meters with the fine and mixed fine-coarse terrigenous lithofacies. We have drawn the seaward extent of this detritus both here and in the Pliocene to correspond with Ridges \#1 and \#2, which Ewing and Lonardi (1971, p. 192) suggest were effective barriers to transport of continental debris into the Argentine Basin. Off the Rio Plata estuary, a distinctive lobe of coarser detritus marks an influx from this large drainage network; this may also represent seaward filling of the Rio Salado Basin, a marginal basin containing Cretaceous and Tertiary sediments (Ludwig et al., 1968; Zambrano and Urien, 1970). A renewed influx of terrigenous material, apparently of a magnitude equal only to the Late Cretaceous influx, had occurred in response to the sequence of short period transgressive-regressive cycles (Figure 2).

Both coarse and fine detritus on or near the Falkland Plateau may indicate current activity. Barker, Dalziel, et al. (1977), for example, describe the Miocene on the plateau as an epoch of erosion by vigorous bottom currents related to the opening of the Drake Passage, or, according to Kennett and Brunner (1973), to a major late Miocene increase in Antarctic ice. In the center of the plateau, a mixed coarse terrigenousbiosiliceous sediment within a narrow north-south zone between two larger carbonate areas probably delineates a major mid-depth passageway for water transport to the north over the plateau. A channel exists here today in which high velocity currents flow to the north over a ripple-marked sea floor (P. Ciesielski, personal communication). Coarse clastic material mixed with biosiliceous detritus just east of the Drake Passage also suggests winnowing by strong currents. The isolated patch of carbonates off the tip of South America, also noted in the Eocene sediments (no data exist here for the Oligocene) consists of calcareous nannofossils, quartz sand, and heavy minerals. Sand and heavy minerals here suggest some current winnowing as well. Modern surface sediments in this area contain distinctive fragments of shells, corals, algae, and bryozoans (Goodell, 1973).

Sediments on the São Paulo Plateau and on the northern margin of South America have a distinctive terrigenous component. Gernerally, however, carbonate sediments were dominant from shelf areas down to the continental slope and partially onto the Brazil Basin floor. Subsidence of the basin floor has placed it well below CCD levels since the Paleocene, and these carbonate deposits here represent bioclastic turbidites (see Site 355, this volume). Slumping and mass wastage of terrigenous material is evident in the northern part of the Brazil Basin (Bader, Gerard, et al., 1970).

Perhaps the most pronounced change in sediment lithofacies patterns is the presence of a distinctive clay sediment extending from the Brazil Basin through the Hunter Channel into the Argentine Basin. One core of this clay (RC15-97) in the Argentine Basin contains only about $20 \%$ biosiliceous material, not enough to be 
designated as a biosiliceous lithofacies, but significantly less than in other cores in the basin that may contain up to $50 \%$ or more of this component. Clearly, by the end of the Miocene, subsidence had produced a deep broad channel between the Mid-Atlantic Ridge and the Rio Grande Rise. We suggest a southerly bottom current through the Hunter Channel on the following basis: (a) paleodepth determinations indicate a channel floor at about 3500-meter depths by the late Miocene (Thiede, in press), deep enough to allow passage of North Atlantic Deep Water (NADW)-note that with glaciation in high northern latitudes NADW would have been a well-established water mass by the late Miocene (Talwani, Udintsev, et al., 1975); (b) the lobate pattern of clays in the Argentine Basin that would suggest southerly dispersal of fine-grained detritus and the lack of a significant biosiliceous admixture to the clayey sediments within the channel or further north, as might be expected were AABW flowing northward; and (c) the narrow sinuous ridges and troughs, mapped on the modern Argentine Basin floor just south of the Hunter Channel by Lonardi and Ewing (1971), which may represent relic depositional and erosional features produced by such a southflowing current. Modern NADW flows through Hunter Channel at depths between 1000 and 4000 meters (Le Pichon et al., 1971). CCD levels in the Miocene were about 3200 meters (minimum depth, Berger and von Rad, 1972), therefore this clay must also partially represent a dissolution facies. Depths in the Hunter Channel area, based upon Rio Grande Rise data (Thiede, in press; Site 357, this volume), would have been about 3000 to 3700 meters-adequate for a southerly flow by NADW and for partial dissolution near the CCD. During the Miocene, therefore, Hunter Channel, became a major conduit for deep-watë exchange between the Brazil and Argentine Basins. Denser AABW was apparently still prevented from flowing to the north. Our data are insufficient to resolve sediment transport in the Vema Channel-Rio Grande Gap, or to infer bottom water exchange through this channel.

In the Angola Basin, a clay component with carbonates could suggest an influx from the Niger River area, or could be a locally derived deposit from the Mid-Atlantic Ridge. The latter interpretation seems preferable since the one sample defining this mixed lithofacies is from a geographic location where a broad physiographic high, the St. Helena area, should have been present.

The influence of the Amazon River is clearly seen as a clay mixture within a large area of carbonate sediments. Its areal distribution appears have to been somewhat further to the south than at present-an indication of weaker clay dispersal mechanisms. At present, clays derived from South America are prevented from dispersal far offshore by the North Brazilian Ridge (Hayes and Ewing, 1970). Thus, by the end of the Miocene the Amazon was probably a large and well-established river system-as postulated by Damuth and Kumar (1975) - with a well-developed but somewhat weaker sediment dispersal system to the north. Calcareous lithofacies southeast of the Amazon area may represent shallower portions of the North Brazilian Ridge, which was somewhat more elevated during the Miocene (Hayes and Ewing, 1970; Bader, Gerard, et al., 1970).

Our data from equatorial areas agree with Ramsey's (1971b) observation that Miocene siliceous sedimentation here had ceased. Clays were dominant between the Sierra Leone Rise and northern Africa. This may be related to the mass wasting and slumping typical of African continental slope and rise areas during the Miocene (Ryan, von Rad et al, 1976), or possibly to an influx of eolian material from Africa comparable to modern distributions of eolian kaolinite (Windom, 1975). Also, during the mid-Miocene, there was a major phase of uplift and erosion of the Atlas Mountains (Vindobonian orogenic phase) which would be expected to have increased the terrigenous component in marine sediments (as seen in Site 139 further to the north on the African continental slope; Hayes, Pimm, et al., 1972; Berger and von Rad, 1972). McMaster et al. (1971) also suggest increased sedimentation off Guinea (opposite the fine terrigenous material near the Sierra Leone Rise) in the late Tertiary, which ceased in the Pliocene because of uplift and capture of drainage systems by the Niger River (see discussion in Dillon and Sougy, 1974).

\section{Carbonates}

Distributions of carbonates are well defined in the Miocene, and show a relationship to bathymetry. The Mid-Atlantic Ridge is outlined by high carbonate values. High values in the area of the St. PaulRomanche and Chain Fracture Zones could represent locally high peaks or uplifted crustal blocks (Bonatti and Honnorez, 1971). Carbonates generally occupied an apparently larger area than in previous epochs even though CCD levels in the Miocene were considerably higher (Figure 2).

Carbonate-rich sediments also delineate the Rio Grande Rise and the Walvis Ridge, and the Hunter Channel is particularly evident from the pattern of sediment containing less than $20 \%$ carbonate content. Two small areas of sediment containing a high percentage of carbonate are distinctive on the Falkland Plateau; the easterly one represents the final occurrence of the carbonate sediment which was accumulating here since the Late Cretaceous. Lower carbonate values between the two patches delineate the longitudinal channel across the plateau (see discussion under Lithofacies).

\section{Foraminifers and Calcareous Nannofossils}

Overall abundances of foraminifers decreased south of the equatorial area, and calcareous nannofossil abundances increased markedly. There is, for example, a distinctive decrease in foraminifer abundances at midlatitudes, particularly noticeable on the Mid-Atlantic Ridge. Nannofossils form the bulk of calcareous material in sediments at higher latitudes, as on the Falkland Plateau, around Bouvet Island, and along the southern portion of the Mid-Atlantic Ridge. This was 
possibly caused by fluctuations in CCD levels; or foraminifers may have been more sensitive to the onset of a generally colder, more zonal circulation. In equatorial areas, the relative variations between nannofossil and foraminifer abundances could also be related to productivity or circulation changes as the closure of the Panama Isthmus and Messinian changes in Mediterranean physiography interrupted Paleogene circulation patterns (Figure 2). Thus, the distinct changes in equatorial distribution patterns may indicate modifications in current systems that occurred in conjunction with these events, as has been inferred from biogeographic and experimental data (Berggren and Hollister, 1974; Luyendyk et al., 1972).

The suggested lobe of lower foraminifer values in surface sediments north of the Walvis Ridge-MidAtlantic Ridge juncture possibly indicates that AABW flowed from the Cape Basin into the southwestern Angola Basin through the Walvis Passage (Connary and Ewing, 1972; 1974), although it is not well illustrated by either the calcareous nannofossil or carbonate distributions.

Higher abundances of calcareous nannofossils off the Amazon River probably resulted from increasing nutrient discharge from this fully developed river system. Calef and Grice (1967) note that under modern conditions copepods are abundant off and north of the present Amazon River. It has been suggested that nannofossil abundance is related to copepod fecal pellet concentration and, therefore, copepod distributions (Honjo, 1975; and F. Wind, personal communication).

\section{Pliocene}

\section{Sediment Lithofacies}

The Pliocene is characterized by a sediment lithofacies distribution somewhat similar to that of today, but with distinctive changes from distributions described for the Miocene. Although data are poor for the Falkland Plateau, there is a suggestion that biosiliceous oozes supplanted Miocene marls. Terrigenous components in southeastern Argentine Basin sediments appear to have decreased proportionately as a result of increasing amounts of biosiliceous material, contributed by $\mathrm{AABW}$ flowing northerly through the Falkland fracture zone. At present, the turbidity of the AABW increases markedly within this area of the basin (Eittreim et al., in press); suggesting dispersion of clays from the South American continent, and re-suspension and dispersion of previously deposited clays. Analogous conditions were probably active in the Pliocene. Terrigenous material from South America continued to be significant on continental margins in the Pliocene in response to transgressive-regressive changes (Figure 2) and the general emergence of continental areas during the Pliocene (Zambrano and Urien, 1970).

South of the Falkland Plateau, a coarse terrigenousbiosiliceous lithofacies represents a winnowed deposit resulting from strong easterly currents out of the Drake Passage. A mixed carbonate-biosiliceous deposit surrounds the Bouvet Island area. The clay component noticeable in sediments west of Bouvet Island and southeast of the Scotia Arc area probably indicates local slumping associated with the eastward extension of the trough marking the Conrad Fracture Zone. This slumping may have been in response to changes in bathymetry related to late Miocene and Pliocene tectonic movements that produced geometric changes in the Bouvet triple junction configuration (Sclater et al., 1976).

Clays had become the dominant sediment type off southern Africa south of the Walvis Ridge and in the Cape Basin, where they occur mixed with biosiliceous components. These clays could have been derived from the Orange River (Dingle, 1971) with dispersal to the south by AABW, assuming bottom-water circulation similar to that of the present (Eittreim et al., in press). The southern boundary of clay dispersal would have been the Agulhas Fracture Zone, which according to Dingle (1973b) and Emery et al. (1975a) formed an effective trap and barrier to any further southerly transport of terrigenous material.

The zone of mixing between carbonate and biosiliceous sediments on the Mid-Atlantic Ridge was now further to the north than it was in the Miocene. A small area of clay on the steeper southern flank of the Walvis Ridge (Goslin et al., 1974) probably represents a local slump deposit, possibly in connection with Neogene tectonic movements (Ewing et al., 1966).

Calcareous sediment distributions continued to correspond to major physiographic features, such as the Mid-Atlantic Ridge, Walvis Ridge, Rio Grande $\mathrm{Rise}$, and the Sierra Leone Rise. In this progressively widening ocean basin, the Mid-Atlantic Ridge has been increasingly isolated from terrigenous contributions and developed higher relief where carbonates were preserved above their dissolution levels, thereby continuing a pattern characteristic of the Cenozoic. Sediment types on the sub-equatorial portions of the Mid-Atlantic Ridge remain poorly defined, but have been depicted on the basis of carbonate sediments described by Cifelli (1970) (not shown on Plates 1 and 2).

Pliocene calcareous sediments occur in the Hunter Channel, implying further subsidence below the influence of the NADW but not below the considerably deeper Pliocene CCD level (Figure 2). The continued presence south of the channel of a clay lithofacies with a minor biosiliceous component suggests that the NADW may have continued to transport fine-grained material southward through the Hunter Channel, depositing it in the Argentine Basin. The variation in biosiliceous content is distinctive; the clay lithofacies (RC12-264 and RC15-96) presumably derived from southward-flowing NADW contains only $10 \%$ to $15 \%$ biosiliceous material, but nearby sediment in the Argentine Basin contains up to $55 \%$ biosiliceous material. No northerly flow of AABW is suggested through the Hunter Channel, although such flow may occur under modern conditions (see Wüst, 1955; Stommel, 1955; Burckle and Biscaye, 1971). Displaced shallow-water carbonates, however, occur in the northern part of the channel (Maxwell, von Herzen, et al., 1970). 
Data for the Rio Grande Gap-Vema Channel are not sufficient to distinguish its role in Pliocene circulation and sedimentation patterns. A tongue of biosiliceousclay sediment, extending northerly from the Argentine Basin toward the Rio Grande Gap-Vema Channel, contains $10 \%$ to $25 \%$ terrigenous material in samples from the slopes of the channel, and could suggest some deep-water exchange from south to north by the close of the Pliocene.

There was a marked increase in the influx of terrigenous detritus along the east coast of South America from the São Paulo Plateau northward. Coarse terrigenous material throughout the Brazil Basin reflects this influx. In the northern part of the basin, coarser detritus was emplaced by turbidity currents (see Site 355, this volume). The lobe of carbonate extending into the Brazil Basin just south of the eastern tip of South America also represents a displaced deposit (Saito et al., 1974).

Calcareous sediments mantled the continental slope and rise south of the Congo (Zaire) River. North of the river, low-carbonate sediments were present in the Pliocene (Gomes, 1969) due to a northerly transport of fluvial sediments (Emery et al., 1974), which resulted in a thick accumulation considerably to the north of the present mouth of the river (Emery et al., 1975b).

The fine terrigenous lithofacies in the Angola Basin, along the east flank of the Mid-Atlantic Ridge and as far south as the Walvis Ridge, may be a contribution from the Congo (Zaire) River and/or a dissolution facies. It seems doubtful that much of this detrital material could have been derived from the Niger River, because of the numerous physiographic barriers interposed, such as the Guinea Rise and the adjacent fracture zones (see Delteil et al., 1974; Emery et al., 1975b). Biosiliceous material is mixed with the clays near the Walvis Ridge, perhaps indicating northerly flow of AABW into the southwestern Angola Basin through the Walvis Passage (Connary and Ewing, 1972, 1974).

In equatorial areas, terrigenous detritus entered from both Africa and the Amazon River. As in the Miocene, the distribution of clays well south of the river may represent dispersal of continental detritus by currents parallel to the North Brazilian Ridge (Hayes and Ewing, 1970). Offshore and north of the river, an increased area of clays mixed with carbonates reflects the continued out-building of the Amazon Cone. The absence of biosiliceous material (present in the Oligocene) may be a result of dilution by terrigenous detritus and of the continued offset of higher productivity zones farther to the northwest, in a manner similar to that described for the Miocene by Ryther et al. (1967). Clay components in sediments off equatorial Africa may have been derived from reworking by bottom currents of slumped and displaced sediments on the continental rise, from continuing input of fluvial sediment (McMaster et al., 1971; Dillon and Sougy, 1974), or from eolian activity. The pattern of fine terrigenous lithofacies south of the Sierra Leone Rise, for example, is similar to the modern distribution of eolian kaolinite suggested by Windom
(1975), although it may also represent transport of clays by bottom currents (Hobart et al., 1975). A minor biosiliceous component in a clay lithofacies at $10^{\circ} \mathrm{N}$ off Africa reflects the equatorial productivity belt; otherwise there is no pronounced indication of this belt.

\section{Carbonates}

Patterns of carbonate contents in Pliocene sediments are similar to those of the modern South Atlantic Ocean (Figure 3). Significantly larger areas of calcareous oozes and marls in the Pliocene ocean, as compared with the Miocene, resulted from the continued lowering of CCD levels (Figure 2), decreased content of terrigenous mixtures in mid-oceanic sediments, and the development of higher topography in the St. Helena Island area (see, e.g., Baker et al., 1967) and on the Mid-Atlantic Ridge. Locally, higher carbonate values result from displaced or reworked calcareous material, such as the foraminiferal sands in Core V9-2 on the southwestern flank of the ridge near the equator. High carbonate values persist on the Sierra Leone Rise which, according to recent drilling, remained above CCD levels through the Pliocene (Lancelot, Seibold, et al., 1975).

On the São Paulo Plateau, the development of algal bioherms, in combination with a southerly-flowing surface current, produced a distinct area of high carbonate values offshore, somewhat analogous to modern conditions, although the modern highcarbonate areas are now separated from the mainland by a zone of low-carbonate sediments (de Melo et al., 1975). Bioclastic turbidites produced the lobe of high carbonate values in the Brazil Basin (see Site 355, this volume). Dilution of carbonates by terrigenous material occurred off the Amazon. In general, the distribution of calcareous material in Pliocene sediments along the Brazilian continental shelf is somewhat similar to that in modern shelf sediments (Milliman, 1975).

Carbonates on the Falkland Plateau had almost disappeared except in one small area. The area of higher carbonate values that had persisted on the northern edge of the plateau from the Late Cretaceous through the Miocene was apparently replaced by biosiliceous sediment, although Pliocene data coverage on the plateau is poor.

In the Angola Basin, low carbonate values in basin sediments resulted both from dilution by terrigenous material and from dissolution of calcareous material below the CCD.

\section{Foraminifers and Calcareous Nannofossils}

Abundances of both foraminifers and calcareous nannofossils are greater in the Pliocene than in previous epochs. High abundances of foraminifers generally outlined the Mid-Atlantic Ridge, Walvis Ridge, and the Rio Grande Rise. In low latitudes, areas with high foraminifer abundance correspond somewhat to modern zones of high abundance of planktonic foraminifers in surface waters (see Bé and Tolderlund, 1971). At middle and lower latitudes (Walvis Ridge-Rio 


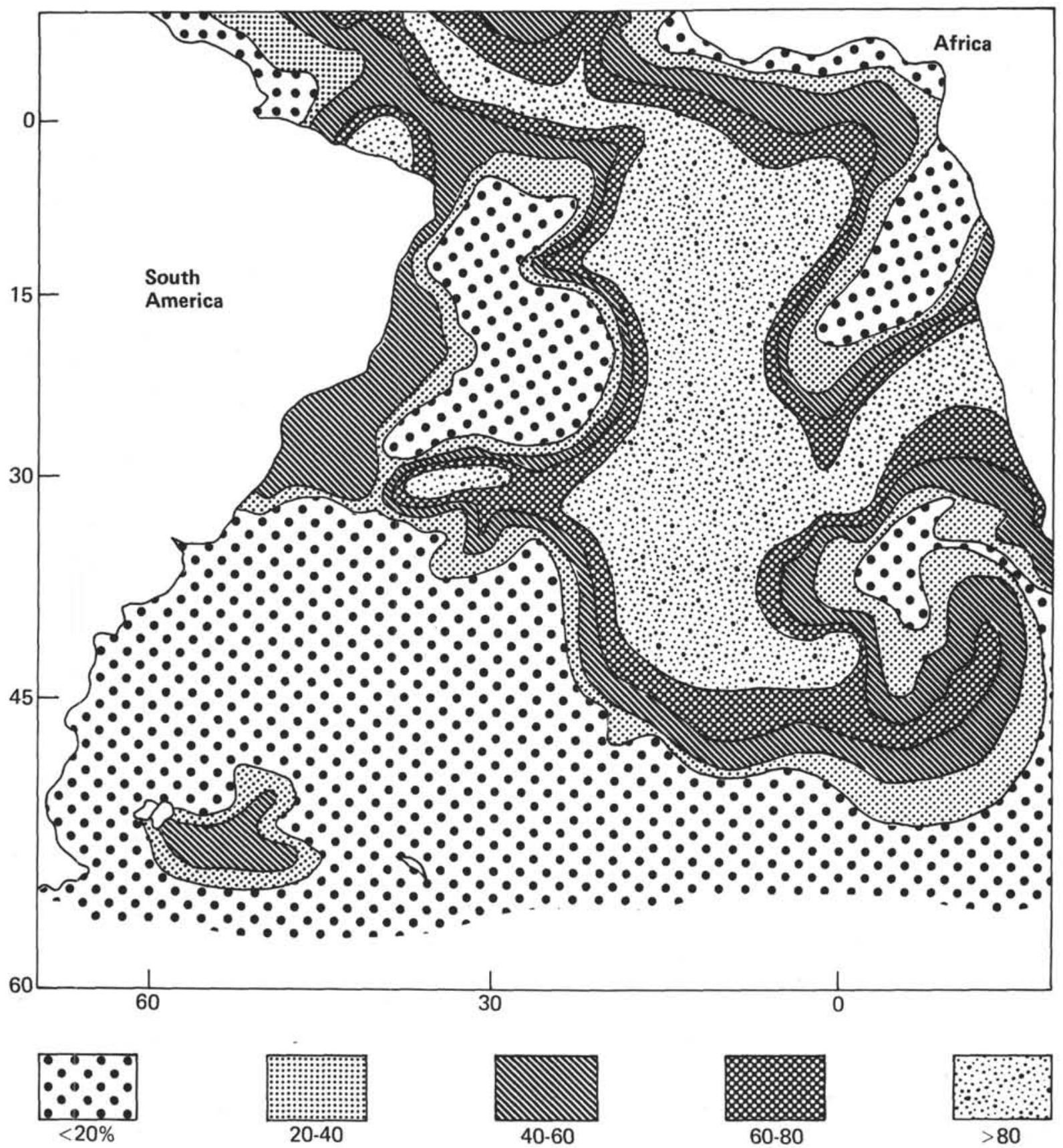

Figure 3. Distribution of $\mathrm{CaCO}_{3}$ in modern ocean sediments (after Biscaye, et al., 1976)

Grande Rise portions of Mid-Atlantic Ridge), Pliocene distributions of high foraminifer abundances appear to be in a complex pattern, although similar to modern zonal distributions (subtropical, tropical, and transitional) of planktonic foraminifers in surface sediments (Bé, in press). The areas of high abundances on and north of the São Paulo Plateau in the Pliocene also corresponds to similar to areas of high planktonic foraminifer abundances in modern surface sediments (Belyaeva, 1976). In the Vema Channel area, the low content $(<10 \%)$ of foraminifers and the much higher content of calcareous nannofossils $(>40 \%)$ in Pliocene sediments compare with modern sediments here that are within the 4000 to 4500 -meter depth range (facies IV of Melguen and Thiede, 1974).

Although calcareous nannofossils generally decrease in abundance at high latitudes on the southern portion of the Mid-Atlantic Ridge and on the Falkland Plateau, their abundance (or preservation) increases markedly at mid-latitudes. Higher abundances occur in sediments along an east-west trend of the São Paulo Plateau-Rio Grande Rise-Walvis Ridge. In equatorial areas, however, abundances appear to decrease on mid-ocean topographic highs, continuing a pattern first noted for the Miocene. Calcareous nannofossils appear in greater abundance along continental margin areas, as between 
the São Paulo Plateau and the Amazon River (in the bioclastic turbidite deposits of the Brazil Basin), in the Sierra Leone Rise area, and along the western African margin north of the Walvis Ridge. Off the Amazon, higher abundance may reflect copepod distributions, as was noted for the Miocene and for modern conditions (Calef and Grice, 1967).

Distributions of both biogenic components in sediments along the margins of the Angola Basin suggest better preservation, or a lower CCD level in this basin than elsewhere in the Pliocene sea. The distinctive tongue of low foraminifer values north of the Walvis Ridge in the southwestern Angola Basin reflects intrusion of AABW into this basin; this effect is not seen as markedly in the calcareous nannofossil distributions. In low latitudes distribution patterns reflect the establishment of near-modern circulation patterns after the blocking of a Tethyan-dominated circulation system during the Miocene.

\section{PALEOCIRCULATION}

\section{Early Cretaceous}

Although lithofacies data are meager for this time slice, the presence of Aptian evaporite deposits imposes certain restrictions on interpreting the Early Cretaceous paleocirculation patterns. Accordingly, the Early Cretaceous is subdivided into two intervals for discussion, the Aptian and the Albian-Cenomanian. The first interval (Figure 4) was characterized by salt and sapropel deposition in a relatively shallow BrazilAngola Basin (Plate 2), and sapropel deposition in the larger Argentine-Cape Basin (Barker, Dalziel, et al., 1976; Ryan and Cita, in press). The only connection to the ancient Pacific-Indian ocean was shallow flow (100$400 \mathrm{~m}$ ) over the Falkland Plateau (Barker, Dalziel, et al., 1977); the South Atlantic was closed to any deep influx from the south. Inflow from the north (Figure 4A) was absent, because of continental configurations. We characterize this as a "mediterranean" Atlantic with a meridional or cross-zonal orientation that was in many respects similar to the Red Sea or Persian Gulf today (Worthington, 1970), but different because of the presence of two distinctive east-west barriers which restricted circulation in the Aptian South Atlantic.

A longitudinal "mediterranean" sea the length of the South Atlantic would be significant because of the effects of lateral and vertical eddy diffusion of heat (Sverdrup, 1939; Neumann and Pierson, 1966, p. 404$405)$. Even with a weak surface temperature gradient, thermal stratification would develop solely as a result of eddy heat conduction, if other effects (such as evaporation-precipitation balance) are disregarded. Since the meridional section of this basin did not extend to cooler polar regions, relatively moderate bottomwater temperatures would be expected.

An Aptian regression (Figure 2) may have partially isolated the shallow northern basin, leading to evaporite deposition (e.g., Ryan, Hsü, et al., 1973; Burke, 1975), but transgressive phases would have allowed the vertical circulation systems of the basins to be closely joined at the Rio Grande Gap (Figure 4B).
At the time an excess of evaporation in the BrazilAngola Basin would have then increased salinity to such an extent that a deep-reaching, haline-driven convection could be produced in the northern reaches of the basin. Relatively slow sinking in the northern part of the basin may have increased oxygen contents of the bottom water to some degree, but the sapropel development attests to the limited extent of this effect. Conditions of oxygen depletion also prevailed in the Argentine-Cape Basin, where salty oxygen-poor bottom waters were slowly introduced over the Rio Grande sill. The oxygen-deficient conditions and the absence of significant deep-water circulation, therefore, resulted from weak mid-Cretaceous climatic zonation and the presence of two effective circulation barriers-the Rio Grande Rise-Walvis Ridge and the Falkland Plateau. This interval of sapropel deposition may also correspond to episodes of sapropel deposition in other Cretaceous ocean basins (Ryan and Cita, in press).

The first interval of the "mediterranean" Atlantic ended with the formation of a deep-water gap in the south, as the eastern end of the Falkland Plateau cleared the southern tip of Africa (see Barker, Dalziel, et al., 1977, for the time sequence).

The second interval of the "mediterranean" Atlantic began during the Albian and continued through the Cenomanian (Plate 6, Early Cretaceous). The presence of Cenomanian sapropel deposits, however, again indicates some restricted bottom circulation (as well as high productivity in the surface waters). Temperature gradients (vertical and horizontal) were still probably quite small because of the weak climatic zonal variations, and high evaporation in the northern regions may still have controlled circulation. The conflict in the southern basin was between salty, oxygen-depleted water entering from the north over the Rio Grande sill, and relatively cool oxygenated deepwater entering from the south through the narrow Falkland-African gap. The intermittent presence of sapropel deposits suggests that oxygen crises occurred as episodic events, with perhaps dry climatic periods (Krinsley and McCoy, this volume) controlling the density characteristics of the water in the northern basin, or sea level fluctuations (Figure 2) controlling the exchange over the relatively shallow Rio Grande sill.

In the surface waters, a weak sub-tropical gyre was probably established in the wider southern basin, while water balance and sea-slope requirements created a flow into the evaporative northern basin. Surface water also continued to enter the South Atlantic over the eastern end of the Falkland Plateau.

\section{Late Cretaceous-Middle Eocene}

The "mediterranean" Atlantic ended during the Turonian with the formation of an equatorial connection between the North and South Atlantic (Premoli-Silva and Boersma, this volume). This Late Cretaceous-early Tertiary time interval is also best divided into two intervals, but here the division is set somewhat arbitrarily. The first interval extends from 
A

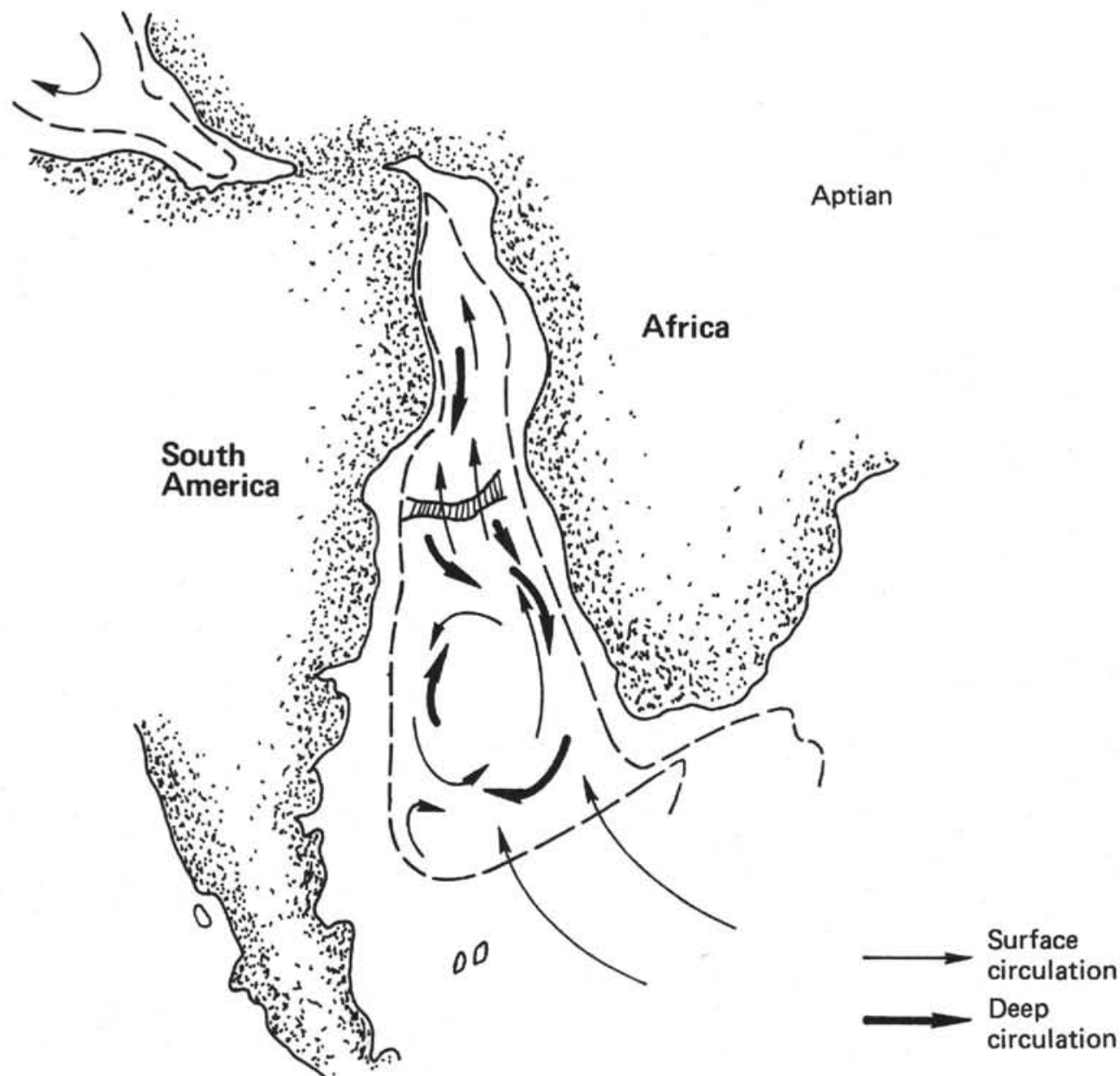

B

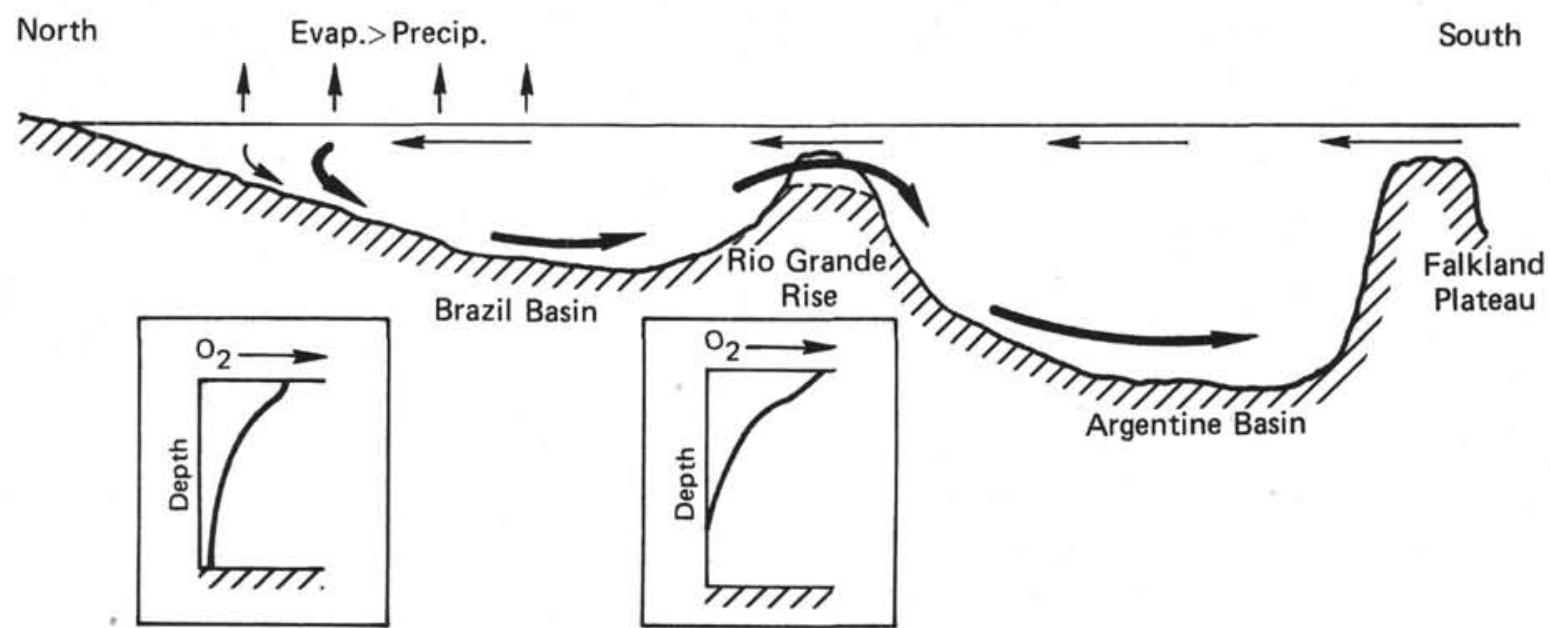

Figure 4. A. Aptian reconstruction of the South Atlantic Ocean with proposed paleocirculation; B. Crosssection of the Aptian South Atlantic illustrating proposed meridional circulation and oxygen profile.

the Turonian to the mid-Campanian, the second from the mid-Campanian to the mid-Eocene. Conditions during the first interval are physically defined by surface or intermediate flow through the shallow equatorial Atlantic passage, with the Rio Grande Rise continuing to act as a barrier for all but surface and near-surface circulation (Figure 5A and B). During the Turonian, shallow inflow also occurred in the 
equatorial region, through the epicontinental Benue Trough connection with the Tethys Sea across northwestern Africa (Reyment and Tait, 1972), an inflow that may have been often vigorous (Adeleye, 1975).

This interval includes the final episodes of sapropel deposition north of the Walvis Ridge (Ryan and Cita, in preparation). Relatively restricted circulation and possibly high productivity, therefore, continued to some extent. A pronounced oxygen-minimum layer may also have been responsible for the Coniacian sapropel deposition in the northern basin; this event corresponds to a worldwide episode of sapropel deposition (Ryan and Cita, in preparation). Deep ventilation of the Argentine-Cape Basin, however, was continually improving as the Falkland-African gap expanded and surface inflow continued over the Falkland Plateau. A primitive equatorial system of surface flow was set up as the North-South Atlantic

A

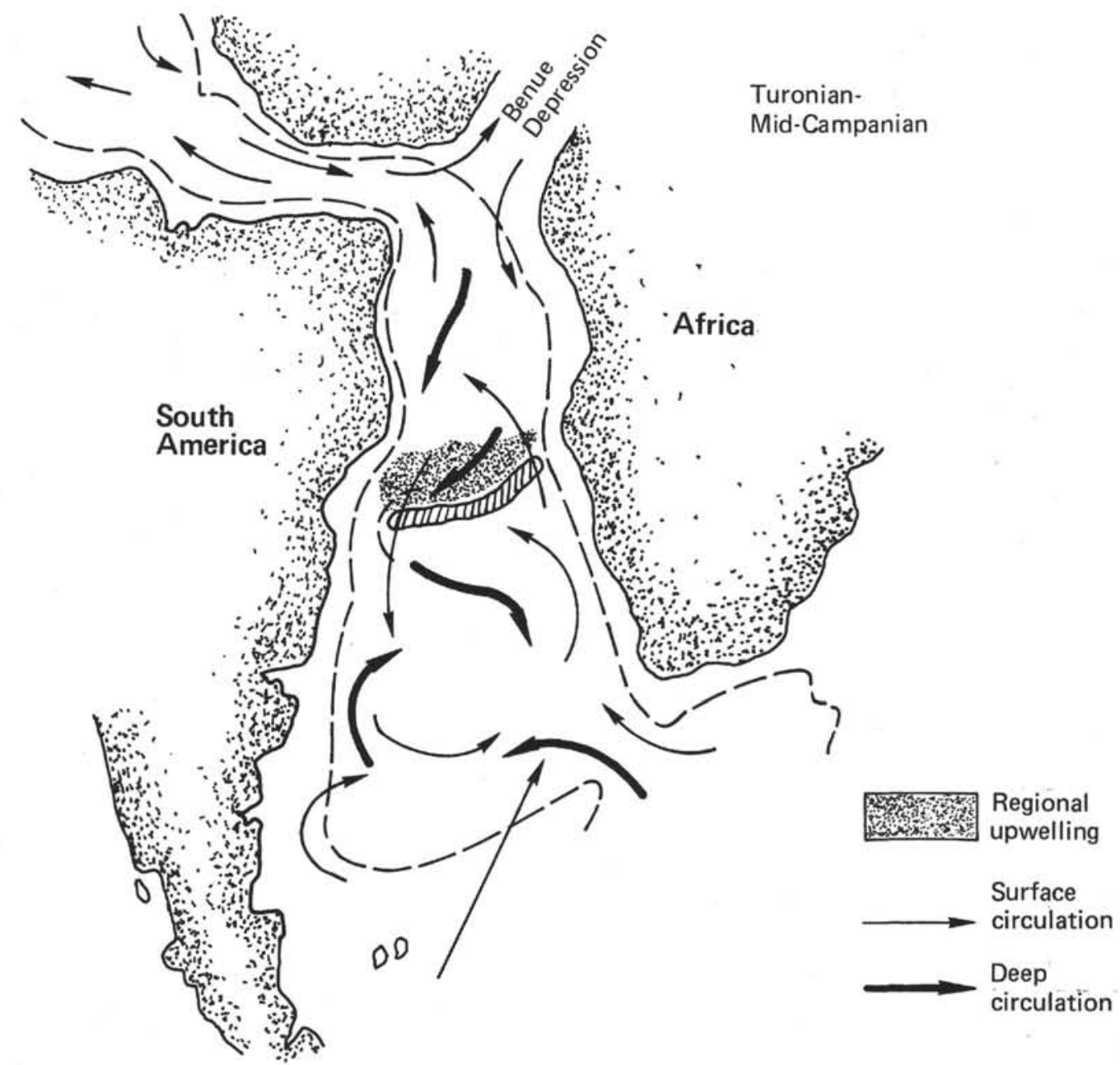

B

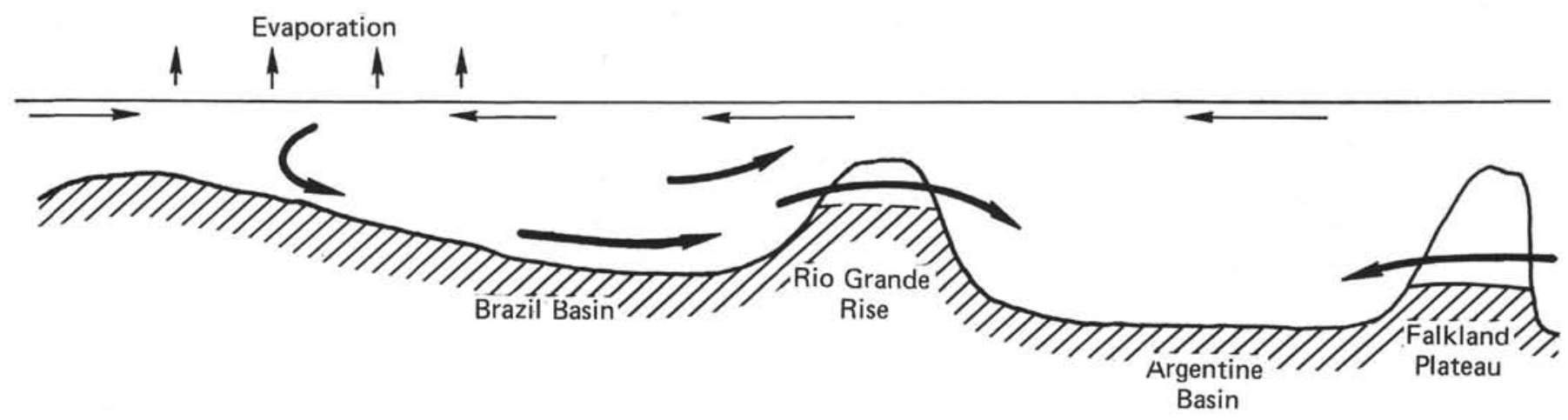

Figure 5. A. Turonain to mid-Campanian reconstruction of the South Atlantic with proposed circulation; B. Crosssection of the above illustrating proposed system of meridional circulation. 
passage expanded. Surface water entered the BrazilAngola Basin from the North Atlantic-Tethys as well as from the south, with the convergence and evaporative processes continuing to produce a down-welling system of salty water (Figure 5B). The up-welling arm of this cell at the Rio Grande-Walvis sill may have increased productivity in this area, creating the oxygen depletion necessary for deposition of the Coniacian sapropel.

The second part of the Late Cretaceous-early Tertiary interval extended from the mid-Campanian through the mid-Eocene (Plate 6-Late Cretaceous and Paleocene charts). The equatorial area deepened and widened, allowing deep-water exchange between the North and South Atlantic; the Tethys-South Atlantic seaway through the Benue Trough disappeared, and the Rio Grande Rise and Gap subsided to allow exchange for all but deep-water circulation. Ventilation of the southern basins was assured by the inflow of oxygenated bottom water from the Indian-Pacific Ocean, but the progressive growth of a significant medial ridge by mid-Eocene separated the bottom currents into two distinct anticyclonic bottom gyres in the Argentine and Cape Basins. This growth of the medial ridge also isolated the deep regions of the Angola Basin from significant bottom current activity. Sporadic tractive bottom currents which developed through the Paleocene effected the distribution of clays and carbonate sediments (Plates 2 and 3). Low zonal gradients of surface temperature were the driving force for this early phase of weak thermohaline circulation.

At the surface, a geostrophic sub-tropical gyre continued to develop and enlarge as the basin expanded. An equatorial current system was also developing, with a nortwesterly flow along the Brazil coast and southeasterly inflow along the southern under-bulge of the African continent. The divergence between these two currents produced an area of relatively high productivity (this current system was south of the paleo-equator, and so produced coastwise components of flow in both currents at the surface), particularly evident in Plates 2 and 3 and in the biosiliceous component in the Eocene lithofacies distribution.

\section{Middle Eocene to Late Eocene}

The appearance of a significant biosiliceous component by the end of the Eocene in Argentine Basin sediments (Plate 2) indicates a strong influx of cool bottom water into the southern reaches of the South Atlantic (Plate 6-Eocene). By analogy with the modern deep- and bottom-circulation systems (Wüst, $1955,1957)$, this influx would have had its origin in the southern polar regions, and is the first indication of the establishment of a meridional circulation pattern reaching throughout the Atlantic. Clearly, production of this water mass was related to the Cenozoic climatic deterioration, which created extreme zonal climatic contrasts concomitant with Antarctic glaciation.

Without reviewing here the arguments and evidence for the sequence of events and the exact timing associated with the initiation and growth of the Antarctic ice sheet (e.g., Frakes and Kemp, 1973;
Kennett et al., 1975), we will accept the following outline as a basis for discussion of oceanographic events: middle to late Eocene climatic deterioration (Douglas and Savin, 1975; Savin et al., 1975; Boersma and Shackleton, this volume) initiated limited ice-sheet formation on the Antarctic continent; continued expansion of the continental ice sheet during the Oligocene; and, completion of the ice cap by the latest Miocene or early Pliocene with the further development of extensive ice shelves. Final construction of the ice sheet was aided by the opening of an AntarcticAustralian seaway (Kennett et al., 1975) and the Drake Passage (Barker, Dalziel, et al., 1976), both during the late Oligocene, to allow formation of the complete circumpolar current.

The formation of present-day Antarctic Bottom Water (AABW) probably requires the presence of both sea ice and extensive ice shelves, where winter cooling and ice formation under the shelf produces the densest water mass $\left(-1.9 \mathrm{C}, 34.62^{\circ} / 00\right)$ in the south polar regions (Fofonoff, 1956; Neumann and Pierson, 1966; Gordon, 1971, 1973). AABW in its present form could not, therefore, have been formed before the late OligoceneMiocene development of ice shelves. The first appearance of the siliceous sediment facies in the Eocene thus predates the formation of ice shelves and true AABW. We propose to term the first cold bottomwater mass produced in the late Eocene and through the Oligocene, where the influence of ice shelves was not significant, as the pre-Antarctic Bottom Water (pAABW), to distinguish it from the later, denser AABW mass.

The circulation pattern of pAABW was similar to the modern bottom-water regime. A western boundary intensification and an Argentine Basin bottom gyre would be expected, but with somewhat reduced velocities because of lower water density contrasts as compared to modern conditions. The northern limit of the biosiliceous facies was the Rio Grande Rise (Plate 2 ); this suggests that the rise acted as an effective barrier to deep current flow farther to the north. Le Pichon et al. (1971) point out that even today AABW passing through the Rio Grande Gap-Vema Channel constitutes only a small proportion of that which enters the Argentine Basin from the south.

The formation of pAABW and the first appearance of the biosiliceous facies also date the commencement of high biological productivity in south polar waters and the upwelling of deep water around the Antarctic continent.

Biosiliceous deposits of the equatorial regions (Plate 2 ) indicate a zone of high organic productivity. This may reflect local upwelling in areas adjacent to the continental margin. Ramsey (1971b, 1973), however, suggests that the global equatorial zone of high productivity extended into the Atlantic during the Eocene. He suggests that the open Panama Straits not only allowed the westward flow of a TethyanEquatorial current, but also allowed eastward-flowing counter- and under-currents, which transported nutrient-rich Pacific water into the Atlantic equatorial area. This would have required a relatively deep $(>200$ 
m) and wide passage to accommodate a fully developed system of equatorial surface currents. Further, the open Panama Straits would have to be centered directly upon the paleo-equator for the subsurface counter-current (the Cromwell Current) to have been operative (Neumann and Pierson, 1966; Knauss, 1961)-an unlikely occurrence, in light of most continental reconstructions (e.g., Phillips and Forsyth, 1972). It is our opinion that the negative surface-water balance created by the Panama outflow may have encouraged widespread upwelling in the equatorial Atlantic, which in turn led to the Eocene high biological productivity.

\section{Oligocene}

Through the Oligocene, Antarctic glaciation (Plate 6), the associated flow of pAABW, and the general thermohaline circulation became firmly established (Plate 6). The Hunter Channel connection between the Brazil and Argentine Basins (Plate II) became an important conduit for south-flowing North Atlantic Deep Water-South Atlantic Deep Water (NADWSADW). The Rio Grande Gap, as today, also formed a conduit for this flow (Johnson et al., in press; Melguen and Thiede, 1974). The floor of Hunter Channel had not subsided sufficiently to allow northward flow of pAABW, and the Rio Grande Rise-Walvis Ridge continued to act as a barrier to bottom-water circulation.

Equatorial biosiliceous productivity apparently diminished. Narrowing of the Panama Straits probably inhibited further outflow into the Pacific and upwelling in the equatorial Atlantic. The preservation of biogenic carbonate (Plate 3 ) and especially calcareous nannofossils (Plate 5) was enhanced partly because of a topographic effect as a consequence of development of a mid-ocean ridge in this area.

\section{Miocene and Pliocene}

All elements of a modern-type circulation system had formed by the close of the Miocene (Plate 6). A through-going Circum-Polar Current had been completed by the early Miocene (Kennett et al., 1975; Barker, Dalziel, 1976), and fully developed ice shelves in the Ross and Weddell seas gave rise to the vigorous meridional bottom current, the AABW. Re-examination of the evidence presented by Le Pichon et al. (1971), on the age of Horizon A in the Vema Channel, suggests that erosion here may date from the inception of $\mathrm{AABW}$ in the late Oligocene-early Miocene (Site Chapter 358 , this volume).

Subsidence of Hunter Channel (Plate 2) produced a deep, broad sill between the Mid-Atlantic Ridge and the Rio Grande Rise. The patterns of sediment distribution in the Miocene imply a continuing southerly deep current (NADW-SADW) through Hunter Channel, and suggest that it had become a major deep-water conduit in the thermohaline system. Continued subsidence through the Pliocene and into the Recent has allowed the channel floor to intersect the AABW-SADW interface producing some, perhaps episodic, AABW transport northward into the southeastern Brazil Basin (Burckle and Biscaye, 1971). With the late Pliocene glaciation of the north polar regions, the thermohaline circulation regime has become fully established.

Continued development of the Mid-Atlantic Ridge in the Neogene divided the South Atlantic sea floor into distinct compartments with respect to deep circulation patterns. We have little data concerning the development of these circulation patterns in the basins of the eastern Atlantic. The distribution of foraminifers (Plate 4) and calcareous nannofossils (Plate 5) suggest, however, that $\mathrm{AABW}$ penetrated into the Angola Basin from the southwest during the Neogene, probably through an ancestral equivalent of the modern Walvis Passage (Connary and Ewing, 1972, 1974).

Elevation of the Isthmus of Panama denied a Pacific outlet for Atlantic equatorial nutrient-poor surface waters, which, therefore, were redirected within the Atlantic. This may have intensified Western Boundary Currents in the North and South Atlantic, and ultimately may have been a key development in establishing the nutrient-flushing mechanism of the Atlantic Ocean (Broecker, 1974).

\section{DISCUSSION}

\section{Terrigenous Influx}

Two distinct episodes of influx from continental areas are apparent: in the Cretaceous, particularly the Late Cretaceous, and during the Miocene and Pliocene. They correspond to similar worldwide instances of pronounced input noted by Davies and Supko (1973) from early DSDP drilling results. These episodes in the South Atlantic are evident both in sediment distribution maps for these epochs (Plate 2) and in the relative increase of coarse terrigenous detritus with respect to other sediment types (Figure 2, Table 2). Variations in fine terrigenous lithofacies do not seem to be as good an indicator, partly because they may represent residues in areas of the sea floor below carbonate dissolution levels.

In the Early Cretaceous, the smaller size of th ; ocean basin, representing its transitional phase from fluviolacustrine conditions to oceanic conditions in a narrow linear trough, allowed all portions of the sea floor to be near continental areas, and surface sediments were accordingly a mixed terrigenouscarbonate type. It is difficult to distinguish the effect upon terrigenous supply produced by the Aptian regression (Figure 2), when evaporite deposition took place in a broad, playa-lake area north of the WalvisRio Grande barrier (the decrease in Aptian terrigenous components shown in Figure 2 results from plotting evaporites on a proportionate scale with all sediment types). The Albian transgression eliminated conditions conducive to salt deposition, and the basin returned to pre-Aptian depositional patterns of carbonate and terrigenous sediments; however, relative variations in rates of supply from continental areas remain difficult to assess.

Data are inadequate to resolve the effect upon terrigenous sedimentation produced by the Turonian 
(Benuetian stage) connection between northern and southern segments of the Atlantic. The concomitant increase in unconformities and inferred hiatuses (Figure 2), however, may indicate extensive dispersal of incoming detritus by tractive bottom currents related to this connection. The terrigenous influx during the Late Cretaceous generally seems to have coincided with the sequence of short period transgression-regression cycles which continued into the Paleocene (Figure 2). Most of the biogenic components in these Cretaceous samples are Maestrichtian (Table 1), but their terrigenous component could also represent some detritus contributed during earlier stages. Except in the far northern portion of the Brazil Basin, Cretaceous clays are all detrital and do not represent a residual deposit beneath carbonate dissolution levels.

The short period transgressive-regressive cycles throughout the Paleocene also seem to have coincided with high inputs of coarse terrigenous material, although significantly less than in the Cretaceous. The increase in fine terrigenous lithofacies, however, represents in part a dissolution residue as larger portions of the Brazil Basin subsided below CCD levels.

Lowest rates of continental detritus supply to the deep sea typify both the Eocene and Oligocene, best indicated by the lower proportions of coarse terrigenous material (Figure 2; Table 2). Despite subsidence of increasingly larger areas of the sea floor below CCD levels, there seems to have been no corresponding increase in fine terrigenous material representing a residual deposit, in part because of the progressive importance of biosiliceous components related to climatic changes. The apparent increase of clays during the Oligocene may be an artifact of the poorer data for this epoch.

Neogene cycles of transgression-regression produced another strong influx of terrigenous sediment, particularly off Argentina and Brazil during the Miocene. The repeated influx of land-derived sediment, especially into the Argentine Basin, resulted in tongues of thicker sediment accumulations that are particularly noticeable in the isopach maps of Ewing et al. (1966, 1973), which are based upon seismic reflection profiles. Distribution of coarse terrigenous lithofacies again depicts the influx best; proportionate variations in clays are more indicative of deep ocean areas below CCD levels, with the exception of continental margin areas and the Amazon drainage network. This Miocene influx represents the largest contribution of material from continental areas into the South Atlantic during the Cenozoic, and again appears related to short period cycles of transgression and regression.

\section{Carbonate Components}

Patterns of high abundances in carbonate components show an interesting change through time. Early Cretaceous distributions are inconclusive, but by the Late Cretaceous (mainly Maestrichtian; see Table 1), a distinct pattern emerges of a broad north-south zone along the central portion of the sea. Lower carbonate values occur along areas adjacent to continents and on the Falkland Plateau, where dilution by non-calcareous debris is important. Despite relatively shallow CCD levels (about $3100 \mathrm{~m}$, Figure 2), dissolution of carbonates below this level apparently occurred only in the northern portion of the Brazil Basin; this suggests a relatively shallow Late Cretaceous ocean.

A distinct change in carbonate distributions occurred in the Paleocene where high values (greater than $80 \%$ ) described an east-west zone in the Rio Grande RiseWalvis Ridge area. Major subsidence of the Brazil Basin and the southern Argentine Basin below CCD levels (Figure 2), accent this trend. The pattern on the ancestral Mid-Atlantic Ridge is poorly defined reflecting the early stages in its development.

These trends continued through succeeding epochs, but by the Miocene a north-south trend became reestablished. The patterns become more striking with increasing subsidence through time of the Argentine, Brazil, Angola, and Cape basins, and the gradients in carbonate values between these basins and the medial ridge structure seem to closely define CCD levels and indirectly define water depth.

Changes in patterns of carbonate contents shown in this study probably reflect the progressive topographic development of the Mid-Atlantic Ridge-from a small, low area extending only slightly north and south of the Rio Grande Rise-Walvis Ridge in the Paleocene, to a feature of high relief similar to the modern ridge system by the Miocene and Pliocene.

This concept agrees with the conclusions of Le Pichon and Hayes (1971), which state that the present Mid-Atlantic Ridge has developed within the last 80 m.y. In many respects, it would also be in accord with "hot spot-mantle plume" concepts proposed by Wilson (1965), Morgan (1971, 1972), Vogt (1971), Vogt and Johnson (1975), and Schilling (1973, 1975a), although there are objections in its applicability to the Rio Grande Rise and Walvis Ridge (Le Pichon and Hayes, 1971; Francheteau and Le Pichon, 1972; Goslin and Sibuet, 1975). Nevertheless, the diachronous development of the ridge may be suggested by the carbonate data, and could have applicability to the use of age-depth curves (Sclater et al., 1971). Further interpretation is complicated by local tectonic and sedimentologic factors, such as uplifted crustal blocks associated with fracture zones (Bonatti and Honnorez, 1971), and displaced calcareous sediments typical of ridge flanks (Berger and Roth, 1975), which would tend to produce serious distortions in carbonate patterns.

\section{Biogenic Components}

Interpretations of the distributions of calcareous nannofossils, foraminifers, and biosiliceous material are difficult because of the qualitative nature of our data, the effects produced by CCD variations, and paleoecological relationships. We have not, for example, differentiated between planktonic and benthic foraminifers, nor between various biosiliceous forms; specific identifications have not been made, and abundances simply represent visual estimates from smear slides. But the relative differences and general 
patterns illustrated in Plates 4 and 5 depict relevant data requiring explanation.

As would be expected, coccoliths are more abundant than foraminifers in smear slide analyses. According to Olausson (1961), it also reflects, in part, fertility changes, so that conditions of lower productivity result in higher proportions of calcareous nannofossils. On Plates 3 and 4, nannofossils are generally more abundant in Cenozoic sediments of the central South Atlantic, an area with low productivity, whereas foraminifers appear to be of greater importance in equatorial regions, areas of higher productivity. Coccoliths are also more readily displaced by bottom currents, leaving foraminifer-enriched sediments on ridges (for example, Pliocene sediments from Core V2559 on the southwestern flank of the equatorial MidAtlantic Ridge).

Influences on the distribution of calcareous biogenic components produced by diversity changes are difficult to assess because of the constraints imposed by preservation, but may be distinguishable in the Late Cretaceous sea where CCD effects appear to have been minimal. Weak latitudinal temperature gradients in the Cretaceous, as compared with the Cenozoic, probably produced the low gradients in foraminifer abundances. Nannofossils do show a latitudinal influence on their abundance in Cretaceous sediments-an influence, which, according to Haq and Lohmann (1975), continued into the Cenozoic, in response to environmental gradients.

It is interesting that the foraminifer content in sediments significantly increased from the Late Cretaceous through the Paleocene and into the Eocene. The apparent increase of foraminifers along coastal South America during the Eocene and later epochs may reflect their dispersal by warm currents, as suggested by Dilley (1973). Other modifications in distribution patterns for both foraminifers and nannofossils during the Miocene and Pliocene could have resulted from changes in oceanic circulation patterns.

Biosiliceous material, as a major component of South Atlantic sediments, became apparent first in the Eocene, then formed a dominant component at high latitudes throughout the Neogene. The increase in productivity of biosiliceous material here is related to the establishment of a modern thermohaline circulation system and cold polar water masses. In equatorial areas, a high content of biosiliceous material implies increased productivity, particularly in the Eocene; Oligocene concentrātions of biosiliceous material may also reflect this or the introduction of nutrient-rich water from an ancestral Amazon River. On the Rio Grande Rise-São Paulo Plateau areas, biosiliceous material occurs in Paleocene and Eocene sediments, and represents a response to vulcanism.

\section{CONCLUSIONS}

Through combination of sediment data from the Deep Sea Drilling Project and from all piston cores and dredges dated as pre-Quaternary, we have constructed a series of sediment distribution maps for the South Atlantic Ocean in the Early and Late Cretaceous and in each of the Cenozoic epochs. These maps illustrate the evolving regional distribution of lithofacies (Plate 2), calcium carbonate contents (Plate 3), foraminifers (Plate 4), and calcareous nannofossils (Plate 5). Similar maps of zeolite distributions in South Atlantic sediments are presented in McCoy et al. (this volume).

Pronounced episodes of terrigenous influx into the South Atlantic from continental areas occurred during the Late Cretaceous, possibly during the Paleocene, and again during the Miocene and Pliocene; they seem to have corresponded to brief yet intense changes in transgression-regression cycles. In the Brazil Basin, terrigenous sediments were dominant from the Paleocene through the Pliocene, as a result also of subsidence of the basin below the CCD. Clays in the Argentine, Cape, and Angola basins all reflect dissolution residues, as well as influx of terrigenous material from surrounding continental areas and redispersion of this material by oceanic currents. Source area changes on adjoining land areas have not been thoroughly investigated. Much information exists from marginal basins along South America and Africa, where key evidence for many of these changes is best preserved. This information is particularly crucial to understanding the early sedimentological history of the South Atlantic Ocean, especially in the Early Cretaceous. Our subdivision into epochs does not give the necessary detail for such comparisons; at this writing, the data simply do not permit further resolution on a regional basis.

Perhaps one of the outstanding results from this study is an independent verification of the sea-floor spreading model for the development of the South Atlantic Ocean. Based upon the maps depicting the ages of oceanic crust by Pittman et al. (1974), all sample locations in Tertiary and Cretaceous time-slices occur without exception within areas of then existent crustal segments. Stratigraphic associations based upon this model proposed by Hess (1962), later termed "plate stratigraphy" by Berger (1973), are thus confirmed through this investigation.

Within the sea-floor spreading model, which provides the gross geomorphology of the basin, the dominant controls on sedimentation in the early history of the South Atlantic Ocean were water depth and transgressive-regressive cycles on adjacent continental margins. Subsidence of peripheral basins and CCD effects also influenced clay distributions, whereas circulation patterns apparently had only secondary effects. Climate changes in the Paleogene led to an intensification of currents which, together with short period transgressive-regressive cycles, influenced terrigenous sedimentation patterns. From the late Eocene through modern time, the strongly zonal climate and its attendant Antarctic circulation system has controlled the movement of bottom waters in the Argentine and Cape Basins. The pronounced decrease in calcareous sediment and increase in deposition of biosiliceous material in the Argentine and Cape Basins from the Oligocene onward is striking in the lithofacies maps. A strong thermohaline circulation gave rise to cold bottom waters flowing north, first as a 
preAntarctic Bottom Water (pAABW) and then as Antarctic Bottom Water (AABW) in the Miocene. Cold North Atlantic Deep Water moved southerly through the Hunter Channel, transporting fineterrigenous sediment into the eastern Argentine Basin. Our data do not allow for a clear assessment on the role of the Vema Channel in South Atlantic circulation. A distinctive equatorial zone of siliceous material has persisted since the Cretaceous, suggesting continuous biological productivity here. The apparently shift of this zone to the south from the Late Cretaceous through the Oligocene probably reflected the southerly movement of the equator relative to the northern rotational component of movement by the South American continent. Paleo-ecological controls are difficult to assess, and much additional work needs to be done with both calcareous and siliceous secreting organisms.

Distributions of carbonate contents in sediments reflect all of these factors, but generally indicate the degree of dilution by terrigenous sediment and preservation on the sea floor with regard to fluctuating CCD levels. Distinct gradients in carbonate values seem to narrowly define CCD levels. In other instances, changes in water depth may point to the progressive development of major sea-floor physiographic features, such as the Mid-Atlantic Ridge.

\section{NOTE ADDED IN PROOF}

Our depiction of Oligocene lithofacies distributions in the Brazil Basin is based upon the recovery of sediments of still uncertain Oligocene age at Site 355 (see Site Chapter). The absence of Paleocene sediments at this site has only recently been indicated although earlier evidence indicated that it may have been present. Nevertheless, there is additional control in the Brazil Basin for this epoch and we believe our patterns are realistic in view of the subsidence history there; Site 355 as a data point for the Paleocene and Oligocene, however, should be treated with caution.

\section{ACKNOWLEDGMENTS}

We appreciate the efforts of many who have assisted us in this study. Micropaleontological age determinations were given on selected samples by Pei Hsin Chen (Lamont-Doherty Geological Observatory), Robert Goll (Duke University) and Hans Thierstein (Scripps Institution of Oceanography). Unpublished data were supplied by Lloyd Burckle, Jim Hays, J.E. Damuth, Peter Thompson (Lamont-Doherty Geological Observatory), and Paul Ciesielski (Florida State University). Carbonate determinations were made by Mark Dobday at Union College. Comments and assistance by a number of people were most helpful; in addition to those above, our efforts have been greatly assisted by Anne Boersma, Joe Morley, and David Cooke (Lamont-Doherty Geological Observatory); Ronald Hedberg (Weeks Associates); and David Johnson (Woods Hole Oceanographic Institution). The manuscript was critically reviewed by A. Boersma, K. Perch-Nielsen, and P. Supko. Their comments and suggestions have been very helpful.

Most samples on which this study is based are from the core laboratory of the Lamont-Doherty Geological Observatory, which is supported by the National Science Foundation through Grant DES72-01568 A04, and by the
Office of Naval Research through Contract N00014-75-C0210. We appreciate the help given by Dennis Cassidy in providing Eltanin samples from the Florida State University core facility, which is supported by the National Science Foundation through Contract NSF C-1059, and by David Johnson in allowing us to use Chain samples from the Woods Hole Oceanographic Institution core facility (supported by National Science Foundation Grant OCE 74-01744 and Office of Naval Research Grant N00014-74-C0262).

\section{REFERENCES}

Adeleye, D.R., 1975. Nigerian Late Cretaceous stratigraphy and paleogeography: Bull. Am. Assoc. Petrol. Geol., v. 59 , p. $2302-2313$.

Asmus, H.E. and Ponte, F.C., 1974. The Brazilian marginal basins. In Nairn, A.E.M. and Stehli, F.G. (Eds.), The ocean basins and margins, v. 1, The South Atlantic: p. 87133.

Bader, R.G., Gerard, R.D., et al., 1970. Initial Reports of the Deep Sea Drilling Project, Volume 4: Washington (U.S. Government Printing Office).

Baker, I., Gale, N.H. and Simons, J., 1967. Geochronology of the St. Helena volcanoes: Nature, v. 215, p. 1451-1456.

Barker, P. Dalziel, I., et al., 1977. The evolution of the southwestern Atlantic Ocean basin; Results of Leg 36, Deep Sea Drilling Project. In Dalziel, I., Barker, P., et al., Initial Reports of the Deep Sea Drilling Project, Volume 36: Washington (U.S. Government Printing Office), p. 993-1014.

Bé, A.W.H., in press. An ecological, zoogeographic and taxonomic review of Recent planktonic foraminifera. In Ramsey, A.T. (Ed.), Oceanic Micropaleontology.

Bé, A.W.H. and Tolderlund, D.S., 1971. Distribution and ecology of living planktonic Foraminifera in surface waters of the Atlantic and Indian Oceans. In Funnell, B.M. and Riedel, W.R. (Eds.), Micropaleontology of oceans: London (Cambridge Univ. Press), p. 105-149.

Belyaeva, N.V., 1976. Quantitative distribution of planktonic foraminifera in the sediments of the world ocean. In Takayanagi, Y. and Saito, T. (Eds.), Progress in Micropaleontology: Spec. Publ., Micropal. Am. Mus. Nat. Hist. Press, p. 10-16.

Berger, W.H., 1973. Cenozoic sedimentation in the eastern tropical Pacific: Bull. Geol. Soc. Am., v. 84, p. 1941-1954.

Berger, W.H. and Roth, P.H., 1975. Oceanic micropaleontology: progress and prospect: Rev. Geophys. Space Phys., v. 13 , p. $561-585$.

Berger, W.H. and von Rad, U., 1972. Cretaceous and Cenozoic sediments from the Atlantic Ocean. In Hayes, D.E., Pimm, A.C., et al., Initial Reports of the Deep Sea Drilling Project, Volume 19: Washington (U.S. Government Printing Office), p. 787-954.

Berger, W.H. and Winterer, E.L., 1974. Plate stratigraphy and the fluctuating carbonate line. In Hsü, K.J. and Jenkyns, H.C. (Eds.), Pelagic sediments on land and under the sea: Spec. Publ. Int. Assoc. Sediment, v. 1, p. 11-48.

Berggren, W.A., 1972. A Cenozoic time scale-some implications for regional geology and paleobiogeography: Lethaia, v. 5, p. 195-205.

Berggren, W.A. and Hollister, C.D., 1974. Paleogeography, paleobiogeography and the history of circulation in the Atlantic Ocean. In Hay, W.W. (Ed.), Studies in paleooceanography: Soc. Econ. Paleontol. Mineral., Spec. Publ. No. 20 , p. 126-186.

Biscaye, P.E. and Eittreim, S.L., in press. Suspended particulate loads and transports in the nepheloid layer of the abyssal Atlantic Ocean. In Heezen, B.C. (Ed.), 
Influence of abyssal circulation on sedimentary accumulation in time and space: Mar. Geol., Spec. Issue.

Biscaye, P.E., Kolla, V., and Turekian, K.K., 1976. Distribution of calcium carbonate in surface sediments of the Atlantic Ocean. J. Geophys. Res., v. 81, p. 2595-2603.

Bolli, H.M., Ryan, W.B.F., et al., 1975. Basins and margins of the eastern South Atlantic; Geotimes, June, p. 22-24.

Bonatti, E. and Honnorez, J., 1971. Nonspreading crusts blocks at the Mid-Atlantic Ridge: Science, v. 174, p. 1329-1331.

Bramlette, M.N., 1958. Significance of cocco-lithophorids in calcium-carbonate deposition: Bull. Geol. Soc. Am., v. 69 , p. 121.

Broecker, W.S., 1974. Chemical oceanography: New York (Harcourt Brace Jovanovich, Inc.), 214 p.

Burckle, L.H. and Biscaye, P.E., 1971. Sediment transport by Antarctic bottom water through the eastern Rio Grande Rise (abst.): Abst. with Prog., v. 3, p. 518-519.

Burke, K., 1975. Atlantic evaporites formed by evaporation of water spilled from Pacific, Tethyan and Southern oceans: Geology, v. 3, p. 613-616.

Burke, K., Dessauvagie, T.F.J., and Whiteman, A.J., 1971. Opening of the Gulf of Guinea and geological history of the Benue depression and Niger Delta: Nature Phys. Sci., v. 233 , p. $51-55$.

Butler, L.W., 1970. Shallow structure of the continental margin, southern Brazil and Uruguay: Bull. Geol. Soc. Am., v. 81, p. 1079-1096.

Calef, G.W. and Grice, G.D., 1967. Influence of the Amazon River outflow on the ecology of the western tropical Atlantic, II. Zooplankton abundance, copepod distribution, with remarks on the fauna of low-salinity areas: J. Mar. Res., v. 25, p. 84-93.

Campos, C.W.M., Ponte, F.C., and Miura, K., 1974. Geology of the Brazilian continental maring. In Burk, C.A. and Drake, C.L. (Eds.), The Geology of continental margins, New York, Heidelberg, Berlin (Springer-Verlag), p. 447-461.

Cifelli, R., 1970. Age relationships of Mid-Atlantic Ridge sediments: Geol. Soc. Am. Spec. Paper 124, p. 47-69.

Cifelli, R., Blow, W.H., and Melson, W.G., 1968. Paleogene sediment from a fracture zone of the Mid-Atlantic Ridge: J. Mar. Res., v. 26, p. 105-109.

Connary, S.D. and Ewing, M., 1972. The nepheloid layer and bottom circulation in the Guinea and Angola Basins. In Gordon, A.L. (Ed.), Studies in physical oceanography, London (Gordon and Breach), p. 169-184.

1974. Penetration of Antarctic Bottom Water from the Cape Basin into the Angola Basin: J. Geophys. Res., v. 79 , p. $463-469$.

Cook, H.E., 1975. North American stratigraphic principles as applied to deep-sea sediments: Bull. Am. Assoc. Petrol. Geol., v. 59, p. 817-837.

Dalziel, I., 1974. Evolution of the margins of the Scotia Sea. In Burk, C.A. and Drake, C.L. (Eds.), The geology of continental margins: New York (Springer-Verlag), p. 567579.

Damuth, J.E., 1973. The western equatorial Atlantic: morphology, Quaternary sediments, and climatic cycles: Ph.D. Dissertation, Columbia University, 602 p.

Damuth, J.E. and Kumar, N., 1975. Amazon Cone: morphology, sediments, age and growth pattern: Bull. Geol. Soc. Am., v. 86, p. 863-878.

Davies, T.A. and Supko, P.R., 1973. Oceanic sediments and their diagenesis: some examples from the DSDP: J. Sediment. Petrol., v. 43, p. 381-390.

Delteil, J.R., Valery, P., Montadert, L., Fondeur, C., Patrait, P. and Mascle, J., 1974. Continental margin in the northern part of the Gulf Guinea. In Burk, C.A. and
Drake, C.L. (Eds.), The geology of continental margins: New York (Springer-Verlag), Heidelberg, Berlin, p. 297 311.

de Melo, U., Summerhayes, C.P., and Ellis, J.P., 1975. Salvador to Vitoria, southeastern Brazil, Part IV. In Milliman, J.D. and Summerhayes, C.P. (Eds.), Upper continental margin sedimentation off Brazil: Contrib. Sedimentol., v. 4, p. 78-116.

Denton, G.H., Armstrong, R.L., and Stuiver, M., 1971. The late Cenozoic glacial history of Antarctica. In Turekian, K.K. (Ed.), The late Cenozoic glacial ages: New Haven (Yale University Press), p. 267-306.

Dilley, F.C., 1973. Larger foraminifera and seas through time. In Hughes, N.F. (Ed.), Organisms and continents through time: Palacont. Soc., London, Spec. Pap. Palaeont. No. 12, p. 155-168.

Dillon, W.P. and Sougy, J.M.A., 1974. Geology of West Africa and Canary and Cape Verde Islands. In Nairn, A.E.M. and Stehli, F.G. (Eds.), The ocean basins and margins, v. 2, The North Atlantic: p. 315-390.

Dingle, R.V., 1971. Tertiary sedimentary history of the continental shelf off southern Cape Province, South Africa: Trans. Geol. Soc. South Africa, v. 74, p. 173-186. 1973a. Regional distribution and thickness of postPalaeozoic sediments on the continental margin of southern Africa: Geol. Mag., v. 110, p. 97-208.

1973b. Mesozoic palaeogeography of the southern Cape, South Africa: Palaeogeo., Palaeoclimat. Palaeoecol., v. 13, p. 203-213.

1973c. Preliminary stratigraphical classification of the Cainozoic succession on the South African continental shelf: Trans. Roy. Soc. S. Africa, v. 40, p. 367-372.

Dingle, R.V. and Scrutton, R.A., 1974. Continental breakup and the development of post-Paleozoic sedimentary basins around southern Africa: Bull. Geol. Soc. Am., v. 85, p. 1467-1474.

Douglas, R.C. and Savin, S.M., 1975. Oxygen and carbon isotope analyses of Tertiary and Cretaceous microfossils from Shatsky Rise and other sites in the North Pacific. In Larson, R.L., Moberly, R., et al., Initial Reports of the Deep Sea Drilling Project, Volume 32: Washington (U.S. Government Printing Office), p. 509-520.

Eittreim, S., Thorndike, E.M., Sullivan, L., in press. Turbidity distribution in the Atlantic Ocean.

Emery, K.O., Lepple, F., Toner, L., Uchupi, E., Rioux, R.H., Pople, W., and Hulburt, E.M., 1974. Suspended matter and other properties of surface waters of the northeastern Atlantic Ocean: J. Sed. Petrol, v. 44, p. 1087-1110.

Emery, K.O., Uchupi, E., Bowin, C.O., Phillips, J., and Simpson, E.S.W., 1975a. Continental margin off western Africa: Cape St. Francis (South Africa) to Walvis Ridge (South-West Africa): Bull. Am. Assoc. Petrol. Geol., v. 59 , p. $3-59$.

Emery, K.O., Uchupi, E., Phillips, J., Bowin, C.O., and Mascle, J., 1975b. Continental margin off western Africa: Angola to Sierra Leone: Bull. Am. Assoc. Petrol. Geol., v. 59 , p. $2209-2265$.

Ewing, M. and Lonardi, A.G., 1971. Sediment transport and distribution in the Argentine margin, basin and related province. In Ahrens, L.H., (Ed.), Physics and chemistry of the Earth, v. 8, p. 123-251.

Ewing, M., Carpenter, G., Windisch, C., and Ewing, J., 1973. Sediment distribution in the oceans; The Atlantic; Bull. Geol. Soc. Am., v. 84, p. 71-88.

Ewing, M., Le Pichon, X., and Ewing, J., 1966. Crustal structure of the Mid-Ocean Ridges, 4. Sediment distribution in the South Atlantic Ocean and the Cenozoic history of the Mid-Atlantic Ridge: J. Geophys. Res., v. 71, p. 16111636. 
Flemming, N.C. and Roberts, D.G., 1973. Tectono-eustatic changes in sea level and seafloor spreading: Nature, v. 243 , p. $19-21$.

Fofonoff, N.D., 1956. Some properties of sea water influencing the formation of bottom water: Deep-Sea Res., v. 4, p. $32-35$.

Frakes, L.A. and Kemp, E.M., 1972. Influence of continental positions on early Tertiary climates: Nature, v. 240, p. $97-$ 100

1973. Paleogene continental positions and evolution of climate. In Tarling, D.H. and Runcorn, S.K. (Eds.), Implications of continental drift to the earth sciences: v. 1, London and New York (Academic Press), p. 535-558.

Francheteau, J. and Le Pichon, X., 1972. Marginal fracture zones as structural framework of continental margins in South Atlantic Ocean: Bull. Am. Assoc. Petrol. Geol., v. 56 , p. $991-1007$.

Funnell, B.M., 1971. The occurrence of pre-Quaternary microfossils in the oceans. In Funnell, B.M. and Riedel, W.R. (Eds.), Cambridge (Univ. Press), The Micropalaeontology of Oceans, p. 507-534.

Geitzenauer, K.R., Margolis, S.V. and Edwards, D.S., 1968. Evidence consistent with Eocene glaciation in a south Pacific deep-sea sedimentary core: Earth Planet. Sci. Lett., v. 4, p. $173-177$.

Gomes, C. de S. Figueiredo, 1969. Evolucao da composicao mineralógica das componentes argilosa e nao argilosa na sondagem Lele-1 (Cabinda-Angola); Servicos de Geologia e Minas, Portugal-Provincia de Angola, Boll. No. 20.

Goodell, H.G., 1973. Marine sediments of the southern oceans. In Goodell, H.G. et al., Marine sediments of the Southern Oceans, Antarctic Map Folio Series, Folio 17, Am. Geographical Society.

Gordon, A.L., 1971. Oceanography of Antarctic waters. In Antarctic Oceanology, I: Am. Geophys. Union, Antarctic Res. Ser., v. 15, p. 169-203.

1973. Physical Oceanography; Antarctic Journal of the United States, vol. 8: Washington (National Science Foundation), p. 61-69.

Goslin, J. and Sibuet, J.C., 1975. Geophysical study of the easternmost Walvis Ridge, South Atlantic: Deep structure; Bull. Geol. Soc. Am., v. 86, p. 1713-1724.

Goslin, J., Mascle, J., Sibuet, J.C., and Hoskins, H., 1974. Geophysical study of the eastern most Walvis Ridge, South Atlantic: morphology and shallow structure: Bull. Geol. Soc. Am., v. 85, p. 619-632.

Hanna, G.D., Hendey, N.I., and Briggs, A.L., 1976. Some Eocene diatoms from South Atlantic cores; Part 1, New and rare species of Arachnoidiscus: Occ. Papers, Calif. Acad. Sci., No. 123, 26 p.

Haq, B., 1973. Transgressions, climatic change and the diversity of calcareous nannoplankton: Mar. Geol., v. 15, M25-M30.

Haq, B.H. and Lohmann, G.P., 1975. Early Cenozoic calcareous nannoplankton biogeography of the Atlantic Ocean; Woods Hole Ocean. Inst. Rept. 75-45, 157 p. (also in press), Marine Micropaleontol., v. 1.

Harrington, H.J., 1956a. Uruguay. In Jenks, W.F. (Ed.), Handbook of South American Geology: Geol. Soc. Am. Mem. 65, p. 119-128.

1956b. Argentina. In Jenks, W.F. (Ed.), Handbook of South American Geology: Geol. Soc. Am. Mem. 65., p. 131-165.

Hayes, D.E. and Ewing, M., 1970. North Brazilian Ridge and adjacent continental margin: Bull. Am. Assoc., Petrol. Geol., v. 54, p. $2120-2150$.
Hayes, D.E., Pimm, A.C. et al., 1972. Initial Reports of the Deep Sea Drilling Project, Volume 19: Washington (U.S. Government Printing Office).

Hays, J.D., 1965. Radiolaria and late Tertiary and Quaternary history of Antarctic Seas; Biology of the Antarctic Seas II: Antarctica Res. Series., v. 5, p. 125184.

Hays, J.D. and Pitman, W.C. III, 1973. Lithospheric plate motion, sea level changes and climatic and ecological consequences: Nature, v. 246, p. $18-22$.

Hess, H.H., 1962. History of ocean basins. In Engel, A.E.J. et al., (eds.), Petrologic studies: a volume to honor A.F. Buddington: Geol. Soc. Am. Spec. Paper, p. 599-620.

Hess, R., Foreman, H.P., Forristall, G.Z., Heezen, B.C., Hekel, H., Hospkins, R.H., Jones, E.J.W., Kaneps, A.G., Krasheninnikov, V., MacGregor, I. and Okada, H., 1974. Walther's facies rule in pelagic realm-a large-scale example from the Mesozoic-Cenozoic Pacific: Z. Deutsch. Geol. Ges., v. 125, p. 151-172.

Hobart, M.H., Bunce, E.T. and Sclater, J.G., 1975. Bottom water flow through the Kane Gap, Sierra Leone Rise, Atlantic Ocean: J. Geophys. Res., v. 80, p. 5083-5088.

Honjo, S., 1975. Dissolution of suspended coccoliths in the deep-sea water column and sedimentation of coccolith ooze. In Dissolution of Deep-Sea Carbonates: Spec. Publ. No. 13, Cushman Found. Foram. Res., p. 114-128.

Honnorez, J., Bonatti, E., Emiliani, C., Bronnimann, P., Furrer, M.A., Myerhoff, A.A., 1975. Mesozoic limestone from the Vema offset zone, Mid-Atlantic Range: Earth Planet Sci. Lett., v. 26, p. 8-12.

Johnson, D.A., 1974. Initial Cruise Report, Chain 115, Leg 6: Woods Hole Ocean. Inst. Tech. Rept. 74-39, 51 p.

Johnson, D.A. and Driscoll, A.H., 1975. Descriptions of WHOI Sediment Cores, v. 4; Woods Hole Ocean. Inst. Tech. Rept. 75-8.

Johnson, D.A., Ledbetter, M., and Burckle, L.H., in press. Vema Channel paleo-oceanography: Pleistocene dissolution cycles and episodic bottom water flow. In Heezen, B.C. (Ed.), Influence of abyssal circulation on sedimentary accumulation in time and space; Mar. Geol., Spec. Issue.

Kennett, J.P. and Brunner, C.A., 1973. Antarctic late Cenozoic glaciation: evidence for initiation of ice rafting and inferred increased bottom-water activity: Geol. Soc. Am. Bull., v. 84, p. 2043-2052.

Kennett, J..P., Burns, R.E., et al., 1972. Australia-Antarctic continental drift, paleocirculation changes and Oligocene deep-sea erosion: Nature Phys. Sci, v. 239, p. 51-55.

Kennett, J.P., Houtz, R.E., et al., 1974. Development of the Circum-Antarctic Current; Science, v. 186, p. 144-147. 1975. Cenozoic paleo-oceanography in the southwest Pacific Ocean, Antarctic glaciation, and the development of the circum-Antarctic current. In Kennett, J.P., Houtz, R.E., et al., Initial Reports of the Deep Sea Drilling Project, Volume 29: Washington (U.S. Government Printing Office), p. 1155-1169.

Knauss, J.A., 1961. The structure of the Pacific Equatorial Countercurrent: J. Geophys. Res., v. 66, p. 143-155.

Kumar, N., Damuth, J.E., and Gorini, M.A., in press. Relict magnesian calcite oolite and subsidence of the Amazon shelf Discussion: Sediment.

LaBrecque, $\mathrm{J}$. in prep.

Ladd, J.W., 1974. South Atlantic sea floor spreading and Caribbean tectonics: Ph. D. Thesis, Geology, Columbia University, New York, 200 p.

Lancelot, Y., Seibold, E., et al., 1975. The eastern North Atlantic: Geotimes, July, p. 18-21.

Le Pichon, X. and Hayes, D.E., 1971. Marginal offsets, fracture zones and the early opening of the South Atlantic: J. Geophys. Res., v. 76, p. 6283-6293. 
Le Pichon, X., Eittreim, S.L., and Ludwig, W.J., 1971a. Sediment transport and distribution in the Argentine Basin. 1. Antarctic bottom current passage through the Falkland Fracture Zone. In Ahrens, L.H. (Ed.), Physics and chemistry of the Earth: v. 8, p. 3-28.

Le Pichon, X., Ewing, M., and Truchan, M., 1971b. Sediment transport and distribution in the Argentine Basin. 2. Antarctic bottom current passage into the Brazil Basin: In Aherns, L.H. (Ed.), Physics and chemistry of the Earth, v. 8 , p. $31-48$.

Leyden, R., Asmus, H., Zembruscki, S., and Bryan, G., 1976. South Atlantic diapiric structures: Bull. Am. Assoc. Petrol. Geol., v. 60, p. 196-212.

Leyden, R., Ludwig, W.J., and Ewing, M., 1971. Structure of continental margin off Punta del Este, Uruguay and Rio de Janeiro, Brazil: Bull. Am. Assoc. Petrol. Geol., v. 55, p. 2161-2173.

Lipps, J.H. and Krebs, W.N., 1974. Planktonic foraminifera associated with Antarctic sea ice: J. Foram. Res., v. 4, p. $80-85$.

Lonardi, A.G. and Ewin̄g, M., 1971. Sediment transport and distribution in the Argentine Basin, 4. Bathymetry of the continental margin. Argentine Basin and other related provinces. Canyons and sources of sediments. In Ahrens, L.H., (Ed.), Physics and chemistry of the Earth, v. 8, p. $79-121$.

Lozano, J.A., 1974. Antarctic sedimentary, faunal and seasurface temperature responses during the last 230,000 years with emphasis on comparison between 18,000 years ago and today: Ph.D. dissertation, Columbia University, $400 \mathrm{p}$.

Ludwig, W.J., Ewing, J. and Ewing, M., 1968. Structure of the Argentine continental margin: Bull. Am. Assoc. Petrol. Geol., v. 52, p. 2337-2368.

Luyendyk, B.P., Forsyth, D., and Phillips, J.D., 1972. Experimental approach to the paleocirculation of the oceanic surface waters: Bull. Geol. Soc. Am., v. 83, p. 2649-2664.

Maxwell, A.E., von Herzen, R., et al., 1970. Deep sea drilling in the South Atlantic: Science, v. 168, p. 1047-1059.

, 1970. Initial Reports of the Deep Sea Drilling Project, Volume 3: Washington (U.S. Government Printing Office), $806 \mathrm{p}$.

McConnell, R.B., 1969. Fundamental fault zones in the Guiana and West African shields in relation to presumed axes of Atlantic spreading; Bull. Geol. Soc. Am., v. 80, p. $1775-1782$.

McIntyre, A. and Bé, A.W.H., 1967. Modern Coccolithophoridae of the Atlantic Ocean, I. Placoliths and Crytoliths: Deep-Sea Res., v. 14, p. 561-597.

McIntyre, A., Ruddiman, W.F., and Jantzen, R., 1972. Southward penetrations of the North Atlantic polar front: faunal and floral evidence of large-scale surface water mass movements over the last 225,000 years: Deep-Sea Res., v. 19, p. 61-77.

McMaster, R.L., Lachance, T.P., Ashraf, A., and de Boer, J., 1971. Geomorphology, structure and sediments of the continental shelf and upper slope off Portuguese Guinea, Guinea and Sierra Leone. In Delaney, G. (Ed.), The geology of the East African continental margin: Great Britain Inst. Geol. Sci. Rep. 70-16, p. 105-119.

Melguen, M. and Thiede, J., 1974. Facies distribution and dissolution depths of surface sediment components from the Vema Channel and the Rio Grande Rise (Southwest Atlantic Ocean): Mar. Geol., v. 17, p. 341-353.

Melguen, M., Bolli, H.M., Ryan, W.B.F., et al., 1975. Facies evolution and carbonate dissolution cycles in sediments form basins and continental margins of the eastern South
Atlantic since early Cretaceous: Publ. 9th Intl. Sed. Cong., Nice.

Milliman, J.D., 1975. A Synthesis. Part VI. In Milliman, J.D. and Summerhayes, C.P. (Eds.), Upper continental margin sedimentation off Brazil: Contrib. Sedimentol., v. 4, p. 131-175.

Milliman, J.D., Summerhayes, C.P., and Barretto, H.T., 1975a. Oceanography and suspended matter off the Amazon River February-March 1973; J. Sediment. Petrol., v. 45, p. 189-206.

1975b. Quaternary sedimentation on the Amazon continental margin: A model: Bull. Geol. Soc. Am., v. 86, p. 610-614.

Morgan, W.J., 1971. Convection plumes in the lower mantle: Nature, v. 230 , p. 42. 1972. Deep mantle convection plumes and plate motions: Bull. Am. Assoc. Petrol. Geol., v. 56, p. 203.

Neumann, G. and Pierson, W.J., Jr., 1966. Principles of physical oceanography: Englewood Cliffs (Prentice-Hall), $545 \mathrm{p}$.

Olausson, E., 1961. Remarks on some Cenozoic core sequences from the central Pacific, with a discussion of the role of coccolithophorids and foraminifera in carbonate deposition: Meddelanden Oceanogr. Inst. Goteborg, v. 29 , p. 5.

Pastouret, L. and Goslin, J., 1974. Middle Cretaceous sediments from the eastern part of Walvis Ridge: Nature, v. 248 , p. $495-496$.

Phillips, J.D. and Forsyth, D., 1972. Plate tectonics, paleomagnetism, and the opening of the Atlantic: Bull. Geol. Soc. Am., v. 83, p. 1579-1600.

Pittman, W.C., Larson, R.L., and Herron, E.M., 1974. The age of the ocean basins: Geol. Soc. Am., v. , p.

Ponte, F.C. and Asmus, H.E., 1976. The Brazilian marginal basins: Current state of knowledge. In de Almeida, F.F.M., (Ed.), Symposium on Continental Margins of Atlantic Type; Sao Paulo, Brazil, p.

Prell, W.L., in press. Evidence for winnowing of deep-sea sediments: Columbia Basin, Caribbean Sea.

Ramsey, A.T.S., 1971a. The study of lower Tertiary calcareous nannoplankton from the North Atlantic Ocean by means of scanning electron microscopy. In Heywood, V.H. (Ed.), Scanning Electron Microscopy; Systematic and Evolutionary Applications: Systematics Assoc. Spec. Vol. 4, London, Academic Press, p. 179-209.

1971b. Occurrence of biogenic siliceous sediments in the Atlantic Ocean: Nature, v. 233, p. 115-117.

1973. A history of organic siliceous sediments in oceans. In Organisms and Continents Through Time, Palaeon. Assoc. London, Spec. Papers in Palaeon., No. 12, p. 199-234.

1974. The distribution of calcium carbonate in deep sea sediments. In Hay, W.W. (Ed.), Studies in Paleooceanography: Soc. Econ. Paleo. Min., Spec. Publ. No. 20 , p. $58-76$.

1976.

Reyment, R.A., 1969. Ammonite biostratigraphy, continental drift and oscillatory transgressions: Nature, v. 224, p. $137-140$.

1973. Cretaceous history of the South Atlantic Ocean. In Tarling, D.H. and Runcorn, S.K. (Eds.), Implications of continental drift to the earth sciences: London, New York (Academic Press), p. 805-814.

Reyment, R.A. and Tait, E.A., 1972. Biostratigraphical dating of the early history of the South Atlantic Ocean: Phil. Trans. Roy. Soc. London, Series B, v. 264, p. 55-95.

Roth, P.H., 1975. Calcareous nannofossils and the Cretaceous oceans: Abst. with Prog., v. 7, p. 1253. 
Ryan, W.B.F. and Cita, M.B., in preparation. Ignorance concerning episodes of ocean-wide stagnation.

Ryan, W.B.F., Cita, M.B., Rawson, M.D., Burckle, L.H., and Saito, T., 1974. A paleomagnetic assignment of Neogene stage boundaries and the development of isochronous datum planes between the Mediterranean, the Pacific and Indian Oceans in order to investigate the response of the world ocean to the Mediterranean "salinity crisis": Riv. Ital. Paleont., v. 80, p. 631-688.

Ryan, W.B.F., Hsu, K.J., et al., 1973. Initial Reports of the Deep Sea Drilling Project, Volume 13: Washington (U.S. Government Printing Office), 514 p.

Ryan, W.B.F., von Rad, et al., 1976. Passive continental margin: Geotimes, October, p. 21-24.

Ryther, J.H., Menzel, D.W., and Corwin, N., 1967. Influence of the Amazon River outflow on the ecology of the western tropical Atlantic, I. Hydrography and nutrient chemistry: J. Mar. Res., v. 25, p. 69-83.

Saito, T. and Funnell, B.M., 1971. Pre-Quaternary sediments and microfossils in the oceans; Chan. 6. In Maxwell, A. (Ed.), The Sea, v. 4, Part I, New York (John Wiley), p. 183-204.

Saito, T. and Van Donk, J., 1974. Oxygen and carbon isotope measurements of Late Cretaceous and early Tertiary foraminifera: Micropaleontology, v. 20, p. 152-177.

Saito, T., Ewing, M., and Burckle, L.H., 1966. Tertiary sediment from the Mid-Atlantic Ridge: Science, v. 151, p. 1075-1079.

Saito, T., Burckle, L.H., and Hays, J.D., 1974. Implications of some pre-Quaternary sediment cores and dredgings. In Hay, W.W. (Ed.), Studies in Paleo-Oceanography: Soc. Econ. Paleon. Min. Spec. Publ. No. 20, p. 6-36.

Savin, S.M., Douglas, R.G., and Stehli, F.G., 1975. Tertiary marine paleotemperatures: Bull. Geol. Soc. Am., v. 86, p. $1499-1510$.

Schilling, J.G., 1973. Iceland mantle plume: geochemical study of Reykjanes Ridge: Nature, v. 242, p. 565.

1975a. Rare-earth variations across "Normal Segments" of the Reykjanes Ridge, $60^{\circ}-53^{\circ} \mathrm{N}$, MidAtlantic Ridge, $29^{\circ} \mathrm{S}$, and East Pacific Rise, $2^{\circ}-19^{\circ} \mathrm{S}$, and evidence on the composition of the underlying lowvelocity layer: J. Geophys. Res., v. 80 , p. 1459-1473.

1975b. Azores mantle blob: rare-earth evidence: Earth Planet. Sci. Lett., v. 25, p. 103-115.

Sclater, J.G., Anderson, R.L., and Bell, M.L., 1971. Elevation of ridges and evolution of the central eastern Pacific: J. Geophys. Res., v. 76, p. 7888-7915.

Sclater, J.G., Bowin, C., Hay, R., Hoskins, H., Pierce, J., Phillips, J., and Tapscott, C., 1976. The Bouvet triple junction: J. Geophys. Res., v. 81, p. 1857-1869.

Shackleton, N.J. and Kennett, J.P., 1975. Late Cenozoic oxygen and carbon isotope changes at DSDP Site 284: Implications for glacial history of the northern hemisphere and Antarctic. In Kennett, J.P., Houtz, R.E., et al., Initial Reports of the Deep Sea Drilling Project, Volume 29: Washington (U.S. Government Printing Office), p. 743-756.

Short, K.C. and Stauble, A.J., 1967. Outline of geology of Niger Delta: Bull. Am. Assoc. Petrol. Geol., v. 51, p. 761779.

Siesser, W.G., 1972. Limestone lithofacies from the South African continental margin: Sediment. Geol., v. 8, p. 83112.
Stommel, H., 1955. The anatomy of the Atlantic: Sci. Am., v. 192 , p. $30-35$.

Stoneley, R., 1966. The Niger Delta region in the light of the theory of continental drift: Geol. Mag., v. 103, p. 385397.

Suarez, M., 1976. Plate-tectonic model for southern Antarctic Peninsula and its relation to southern Andes: Geology, v. 4, p. 211-214.

Sverdrup, H.U., 1939. Lateral mixing in the deep water of the South Atlantic Ocean: J. Mar. Res., v. 2, p. 195-207.

Talwani, M. Udintsev, G., et al., 1975. Leg 38: Geotimes, February, p. 24-26.

Thiede, J. in press. The subsidence of aseismic ridges: Evidence from sediments on Rio Grande Rise (SW Atlantic Ocean): Bull. Am. Assoc. Petrol. Geol.

Urien, C.M. and Zambrano, J.J., 1974. The geology of the basins of the Arge.tine continental margin and Malvinas Plateau. In Nairn, A.E.M. and Stehli, F.G. (Eds.), The ocean basins and margins, v. 1, The South Atlantic: p. 135-169.

Van Andel, Tj. H., 1975. Mesozoic/Cenozoic calcite compensation depth and the global distribution of calcareous sediments: Earth Planet. Sci. Letters, v. 26, p. 187-194.

Van Andel, Tj.H. and Heath, G.R., 1970. Tectonics of the Mid-Atlantic Ridge, 6-8 $8^{\circ}$ south latitude: Mar. Geophys. Res., v. 1, p. 5-36.

Van Hinte, J.E., 1976. A Cretaceous time scale: Bull. Am. Assoc. Petrol. Geol., v. 60, p. 498-516.

Vogt, P.R., 1971. Asthenosphere motions recorded by the ocean floor south of Iceland: Earth Planet. Sci. Lett., v. 13 , p. $153-160$.

Vogt, P.R. and Johnson, G.L., 1975. Transform faults and longitudinal flow below the mid-oceanic ridge: J. Geophys. Res., v. 80, p. 1399-1428.

Whitten, E.H., 1976. Cretaceous phases of rapid sediment accumulation, continental shelf, eastern U.S.A.: Geology, v. 4 , p. $237-240$.

Wilson, J.T., 1965. A new class of faults and their bearing on continental drift: Nature, v. 207, p. 342-343.

Windom, H.L., 1975. Eolian contributions to marine sediments: J. Sediment. Petrol., v. 45, p. 520-529.

Worsley, T.R. and Jorgens, M.L., 1974. Oligocene calcareous nannofossil provinces. In Ross, C.A. (Ed.), Paleogeographic Provinces and Provinciality: Soc. Econ. Paleont. Min. Spec. Publ., v. 21, p. 85-108.

Worsley, T.R. and Martini, E., 1970. Late Maestrichtian nannoplankton provinces: Nature, v. 225, p. 1242-1243.

Worthington, L.V., 1970. The Norwegian Sea as a Mediterranean basin: Deep-Sea Res., v. 17, p. 77-84.

Wright, J.B., 1968. South Atlantic continental drift and the Benue Trough: Tectonophysics, v. 6, p. 301-310.

Wüst, G., 1955. Stromgeschwindigkeiten in Tiefen-und Bodenwasser des Atlantischen Ozeans. Papers in Marine Biology and Oceanography, Bigelow Vol.: Deep Sea Res., p. 373-397.

1957. Stromgeschwindigkeiten und Strommengen in den Tiefen des Atlantischen Ozeans: Meteor-Werk, v. 6, p. $261-420$.

Zambrano, J.J. and Urien, C.M., 1970. Geological outline of the basins in southern Argentina and their continuation off the Atlantic shore: J. Geophys. Res., v. 75, p. 13631396. 